\begin{abstract}
UNIVERSIDADE DE BRASÍLIA
FACULDADE DE CIÊNCIAS DA SAÚDE

PROGRAMA DE PÓS-GRADUAÇÃO EM ENFERMAGEM
\end{abstract}

JOYCE SILVA DOS SANTOS

ESTUDO MORFOLÓGICO E MORFOMÉTRICO DO PROCESSO DE CICATRIZAÇÃO EM RATOS WISTAR ADULTOS TRATADOS COM CREME DE ÓLEO DE ROSA MOSQUETA

BRASÍLIA - DF 


\author{
UNIVERSIDADE DE BRASÍLIA \\ FACULDADE DE CIÊNCIAS DA SAÚDE \\ PROGRAMA DE PÓS-GRADUAÇÃO EM ENFERMAGEM
}

JOYCE SILVA DOS SANTOS

ESTUDO MORFOLÓGICO E MORFOMÉTRICO DO PROCESSO DE CICATRIZAÇÃO EM RATOS WISTAR ADULTOS TRATADOS COM CREME DE ÓLEO DE ROSA MOSQUETA

Dissertação apresentada como requisito parcial para obtenção do título de Mestre em Enfermagem pelo Programa de Pós-Graduação em Enfermagem da Universidade de Brasília. Área de Concentração: Cuidado, Políticas e Práticas em Saúde e Enfermagem.

Linha de pesquisa: Processo de Cuidar em Saúde e em Enfermagem.

Orientador: $\operatorname{Prof}^{\mathrm{a}} \operatorname{Dr}^{\mathrm{a}}$ Ivone Kamada

Coorientador: $\operatorname{Prof}^{\mathrm{a}} \mathrm{Dr}^{\mathrm{a}}$ Lívia Cristina Lira de Sá Barreto

BRASÍLIA - DF 
JOYCE SILVA DOS SANTOS

\section{ESTUDO MORFOLÓGICO E MORFOMÉTRICO DO PROCESSO DE CICATRIZAÇÃO EM RATOS WISTAR ADULTOS TRATADOS COM CREME DE ÓLEO DE ROSA MOSQUETA}

Dissertação apresentada como requisito parcial para obtenção do título de Mestre em Enfermagem pelo Programa de Pós-Graduação em Enfermagem da Universidade de Brasília. Área de Concentração: Cuidado, Políticas e Práticas em Saúde e Enfermagem.

Linha de pesquisa: Processo de Cuidar em Saúde e em Enfermagem.

APROVADA EM:

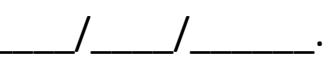

\footnotetext{
Doutora: Ivone Kamada

(Presidente)

Doutora: Ana Lúcia da Silva (Professor)

Doutor: João Batista de Sousa

(Professor)

Doutora: Ana Beatriz Duarte Vieira (Suplente)
} 
Dedico este trabalho...

a Deus, que abriu cada uma das portas e janelas pelas quais este estudo pode ser levado avante; a minha família e amigos por seu apoio incondicional; a meu amado e melhor amigo com quem tenho compartilhado meus sonhos e que está sempre perto me incentivando a ir mais longe; a cada pessoa que de alguma forma, já sentiu a dor de uma ferida... 


\section{AGRADECIMENTOS}

Este é um trabalho de múltiplos esforços, de conhecimentos diversos e combinados. Obrigada, Prof ${ }^{a}$. Dr ${ }^{\mathrm{a}}$ Ivone Kamada por ter acreditado nessa proposta e me aceitado como orientanda mesmo quando a tarefa parecia impossível frente aos recursos disponíveis. Obrigada Prof ${ }^{a}$. Dr ${ }^{a}$ Lívia Cristina Lira de Sá Barreto por ter acolhido esta aluna que ainda não estava bem consciente da longa tarefa que teria pela frente. De uma forma tão desprendida você se doou para este estudo e trouxe novas perspectivas.

Prof $^{\mathrm{a}}$. Dr ${ }^{\mathrm{a}}$ Izabel Cristina Rodrigues da Silva, a você, meus agradecimentos por sua disponibilidade e auxílio em cada fase desse trabalho. Sua paixão pela pesquisa e a forma

como você se faz acessível àqueles que buscam por conhecimento me inspiraram! Aos veterinários do Biotério Central da Faculdade de Medicina Rafael Rocha de Andrade e

Ana Luiza Sarkis Vieira, obrigada pelas lições de respeito e cuidado com os animais, que contribuíram com suas vidas para o desenvolvimento desse estudo.

Também agradeço a cada um dos técnicos do Biotério Central da Faculdade de Medicina que com paciência garantiam o bem estar dos animais durante o andamento do estudo. Às alunas de Graduação em Enfermagem e futuras colegas de profissão Íris Caroline, Jéssica Alves Rodrigues, Kelly Adriane Bomfim de Castro, Laura Beatriz Sousa de Jesus Martelleti,

Patrícia Nunes Barbosa Soares, meu muito obrigada pelas infindas horas dedicadas em procedimentos anestésicos, cirúrgicos e coletas de sangue e fragmentos. Este trabalho, de alguma forma, também lhes pertence, pois sem a dedicação e o esforço de vocês, nada teria sido feito. Obrigada também aos técnicos do Laboratório de Patologia Elisabete Joaquim dos

Santos e Bráulio, à técnica do Laboratório de Histologia Maria da Glória da Silva, e ao farmacêutico responsável pelo Laboratório de Tecnologias da Faculdade de Ceilândia Antônio Leonardo de Freitas Garcia pelo apoio e pelas vezes que tiveram que parar seus afazeres para me orientar nos experimentos. Em especial, agradeço à Tercia María Mendes Louza de Castro, que com alegria e disposição abriu as portas do Laboratório de Patologia e não hesitou em compartilhar comigo seus conhecimentos.

Aos professores doutores Eliana Fortes Gris, Fabiana Pirani Carneiro e Daniel Oliveira Freire agradeço por terem dedicado seu tempo para as análises que compõe cada parte deste trabalho. $\mathrm{O}$ conhecimento de cada um de vocês possibilitou a montagem deste quebra-cabeça. 
Obrigada à Eliane Caixeta, farmacêutica da Farmácia Universitária da Universidade Federal de Goiás, que me recebeu de forma tão atenciosa e foi essencial para a aquisição dos insumos usados nesse estudo.

Um agradecimento especial à mestranda Natane Castelo Branco Duarte que me doou vários de seus dias em procedimentos de laboratório além da paciência de ser também minha professora.

Agradeço às (o) alunas (o) de graduação Amanda Almeida, Andressa Guimarães e Igor Mota por tomarem alguns dias do tribulado tempo de vocês para me conduzirem na jornada de desvendar os caminhos das Ciências Farmacêuticas.

À minha querida amiga Fabiana Carpi, minha irmã Tayse Santos e a meu pai João Batista dos Santos, obrigada por terem sido minha salvação quando parecia que eu estava sozinha. Vocês também se debruçaram sobre animais, coletaram fragmentos, puncionaram, e fizeram coisas que jamais fariam em outras situações. Vocês são minha âncora!

À minha querida mãe Ruth Silva dos Santos, obrigada por ser minha fortaleza e por ter me ensinado a permanecer em pé frente às tempestades... porque a vida é um ir e vir de tempestades.

Obrigada aos meus amigos que me incentivaram, apoiaram, acalmaram e me distraíram nos momentos em que precisei.

A meu companheiro e amigo Marcos Antônio Pereira, obrigada por me incentivar, dar a mão quando preciso, ou simplesmente estar ao meu lado nos bons e nos maus momentos.

Obrigada querida família por ser meu porto seguro quando a tensão parecia maior do que a tarefa a que me dediquei nesses dois anos.

E obrigada, meu Deus, porque a cada passo, vi Tua providência e direção nesse caminho, me fazendo ir mais além do que podia imaginar.

"Que eu saiba agradecer o pouco, para que possa merecer o muito".

Anônimo

A todos vocês,

Muito Obrigada! 
"no calor da fornalha separa-se, para sempre, a escória da prata e do ouro..."

(Ellen White) 


\section{$\underline{\text { RESUMO }}$}

Feridas crônicas atingem cerca de $15 \%$ da população mundial trazendo consequências sociais, econômicas e psicológicas a seus portadores. Na tentativa de reduzir esse índice novas tecnologias e o uso de produtos naturais anti-inflamatórios tem sido abordados por diversos pesquisadores como recursos mais convenientes para a prevenção e tratamento de feridas crônicas. O óleo de Rosa Mosqueta (RM) possui uma vasta gama de substâncias naturais com capacidade anti-inflamatórias e provável propriedade cicatrizante como o betacaroteno e os ácidos graxos oleico, linoleico, linolênico e ursólico. Diante do exposto, o presente estudo teve por objetivo aliar a terapia clínica à tecnologia farmacêutica, incluindo o óleo RM em um produto elegante, estável e com efetividade na cicatrização de feridas crônicas. Para tanto, o trabalho foi estruturado em três etapas, sendo a primeira delas a busca de literatura científica que justificasse o desenvolvimento de um produto farmacêutico contendo óleo de RM; a segunda consistiu no desenvolvimento do produto, emulsão a base de óleo de RM, assim com a execução de seu estudo de estabilidade acelerada, finalizando com a terceira etapa através da avaliação da eficácia in vivo da emulsão de óleo de RM em comparação ao óleo de RM puro. Foram elaboradas emulsões óleo em água (O/A) com óleo de RM em quatro diferentes concentrações $(15 \%, 25 \%, 30 \%, 50 \%)$. A emulsão mais concentrada e com melhor característica estética (30\% de óleo de RM - E30), juntamente com emulsão de óleo mineral 30\% (OM30), amostra de óleo de RM puro (S100) e solução a 30\% de óleo RM (S30) foram submetidas ao estudo de estabilidade acelerada em câmara climática $\left(40^{\circ} \mathrm{C}\right.$ e $75 \%$ UR) por 90 dias. Os parâmetros físico-químicos (cor, odor, consistência, cremeação, espalhabilidade e $\mathrm{pH}$ ), químicos - (capacidade antioxidante e dosagem de betacaroteno) e microbiológicos das emulsões e soluções oleosas previamente citadas foram analisados nos dias 1, 7, 15, 30, 60, e 90 após elaboração e envase. Em adição, as emulsões (E30 e OM30) e soluções recémelaboradas (S30 e S 100), assim como gel de colágeno a 50\% (controle positivo - C50) e solução fisiológica $0,9 \%$ (controle negativo - SF) foram utilizados em estudo in vivo com 144 ratos Wistar adultos aleatorizados em 6 grupos de tratamento. Os animais foram anestesiados e submetidos ao procedimento cirúrgico para retirada de fragmento da região dorsal até exposição da fáscia muscular. As lesões foram tratadas diariamente utilizando cada produto de acordo com o grupo de análise e avaliadas quanto à presença de fibrina, necrose ou granulação em leito e taxa de retração. Nos dias 7, 14 e 21 de cicatrização, 8 animais de cada grupo foram eutanasiados para coleta dos fragmentos da lesão usados na confecção de lâmina histológica. As lâminas foram coradas por hematoxilina eosina para avaliação de infiltrado inflamatório, neoangiogênese e reepitelização e pela coloração picrosírius para avaliação da deposição e organização de colágeno. A análise estatística foi realizada em programa SPSS 20.0, considerando-se valores significantes $\mathrm{p} \leq 0,05$. A emulsão E30 elaborada mostrou características organolépticas, espalhabilidade e de $\mathrm{pH}$ adequadas à aplicação tópica, apresentando estabilidade físico-química pelo período de 30 dias nas condições de armazenamento desse estudo. Obteve capacidade antioxidativa superior ao óleo puro, indicando que a formulação protegeu os componentes químicos do óleo. Os testes in vivo mostrou que a emulsão E30 estimulou o influxo de neutrófilos nos primeiros 14 dias de cicatrização e reduziu o número de monócitos no leito da lesão aos 21 dias comparado ao grupo SF. Também mostrou menor formação de tecido necrótico e fibrinoso em leito comparado aos demais grupos.

Palavras-chave: Rosa aff rubiginosa, óleo de Rosa Mosqueta, creme de Rosa Mosqueta, cicatrização de feridas. 


\begin{abstract}
$\underline{\text { ABSTRACT }}$
Chronic wounds affect about $15 \%$ of the world population bringing social, economic and psychological consequences to their patients. In an attempt to reduce that, new technologies index and the use of natural anti-inflammatory products have been approached by several researchers to due more convenient resources for the prevention and treatment of chronic wounds. Rosehip oil (RM) has a wide range of natural substances with anti-inflammatory capacity and probable healing properties such as beta-carotene and oleic, linoleic, linolenic and ursolic fatty acids. In view of the above, the present study aimed to combine clinical therapy with pharmaceutical technology, including RM oil in an elegant, stable product to effective healing of chronic wounds. For this, the work was structured in three stages, the first one being the research of scientific literature that justified the development of a pharmaceutical product containing RM oil; the second consisted of the development of the product, emulsion based on RM oil, as well the execution of its accelerated stability study, finishing with the third stage by evaluating the in vivo efficacy of the RM oil emulsion compared to the pure RM oil. The emulsions oil in water $(\mathrm{O} / \mathrm{W})$ were prepared with $\mathrm{RM}$ at four different concentrations $(15 \%, 25 \%, 30 \%, 50 \%)$. The most concentrated emulsion with the best aesthetic characteristics (30\% of RM-E30 oil), together with $30 \%$ mineral oil emulsion (OM30), pure RM oil sample (S100) and 30\% RM oil solution (S30) were submitted to the accelerated Stability study in climatic chamber $\left(40^{\circ} \mathrm{C}\right.$ and $\left.75 \% \mathrm{RH}\right)$ for 90 days. The physicochemical parameters (color, odor, consistency, scaling and $\mathrm{pH}$ ), chemical (antioxidant capacity and dosage of betacarotene) and microbiological parameters of the emulsions and oily solutions were analyzed on days 1, 7, 15, 30, 60, and 90 after elaboration and packaging. In addition, emulsions (E30 and OM30) and freshly prepared solutions (S30 and S100), as well as 50\% collagen gel (positive control - C50) and $0.9 \%$ physiological solution (negative control - SF) were used in vivo study with 144 adult Wistar rats randomized into 6 treatment groups. The animals were anesthetized and submitted to a surgical procedure to remove the fragment from the dorsal region until exposure of the muscular fascia. Lesions were treated daily using each product according to the analysis group and evaluated for the presence of fibrin, necrosis or bed granulation and retraction rate. On days 7, 14 and 21 of healing, 8 animals from each group were euthanized to collect the lesion fragments used in the histological slide preparation. The slides were stained by hematoxylin eosin for the evaluation of inflammatory infiltrate, neoangiogenesis and reepithelialization and by picrosirius staining to evaluate the deposition and organization of collagen. The statistical analysis was performed in SPSS 20.0 program, considering significant values $\mathrm{p} \leq 0.05$. The elaborated E30 emulsion showed organoleptic, scatterability and $\mathrm{pH}$ characteristics suitable for topical application, presenting physical-chemical stability for the period of 30 days under the storage conditions of that study. It obtained antioxidative capacity superior to pure oil, indicating that the formulation protected the chemical components of the oil. In vivo tests showed that the E30 emulsion stimulated the influx of neutrophils within the first 14 days of healing and reduced the number of monocytes in the lesion bed at 21 days compared to the SF group. It also showed lower formation of necrotic and fibrinous tissue in wound bed compared to the other groups.
\end{abstract}


Key Words: Rosa aff rubiginosa, Rose hip oil, Rose hip cream, wound healing. 


\section{$\underline{\text { RESUMEN }}$}

Las heridas crónicas afectan a alrededor del 15\% del mundo trayendo consecuencias social, económica y cambios psicológicos a sus portadores. En un intento de reducir esta tasa, nuevas tecnologías y la utilizacíon de productos naturales antiinflamatorios há sido abordado por varios investigadores como recursos más convenientes para la prevención y el tratamiento de heridas crónicas. El aceite de rosa mosqueta tiene una amplia gama de sustancias naturales capaces de acción antiinflamtória y probable cicatrización de heridas como beta-caroteno y ácidos grasos oleico, linoleico, linolénico y ursólico. Por lo tanto, el objetivo de este estudio fue combinar la terapiaclínica con la tecnología farmacéutica, incluyendo el aceite de rosa mosqueta en un producto elegante, estable y con eficacia en la curación de heridas crónicas. Por lo tanto, los trabajos se han estructurado en tres partes, la primera de las quales la búsqueda de la literatura científica que justifica el desarrollo de un producto farmacéutico que contiene aceite de RM, la segunda consistió en el desarrollo de la emulsión de aceite de base RM así como la realización de su estudio de estabilidad acelerada, terminando con la terceira etapa através de evaluación de la eficacia in vivo de la emulsión de aceite de la RM en comparación con aceite puro de RM. Se han preparado las emulsiones aceite em agua (O/W) con aceite de RM em cuatro diferentes concentraciones (15\%, 25\%, 30\%, 50\%). La emulsión más concentrado y con mejor función estética (30\% de aceite de RM - E30), junto con la emulsión de aceite mineral 30\% (OM30), las muestras de aceite puro de RM (S100) y 30\% de aceite RM ( S30) fueron sometidos al estudio de estabilidad acelerada en cámara climática $\left(40{ }^{\circ} \mathrm{C}\right.$ y $75 \% \mathrm{HR}$ ) durante 90 días. Los parámetros físicos y químicos (color, olor, textura, formación de crema, extensibilidade y $\mathrm{pH}$ ), químicos - (la capacidad antioxidante y la dosis de beta-caroteno) y microbiológico de las emulsiones y soluciones grasosas, mencionadas anteriormente, fueron examinados en $\operatorname{los}$ días 1, 7, 15, 30, 60 y 90 después de su acondicionamiento y envasado. Además, las emulsiones (S30 y OM30) y soluciones recién desarolladas (S30 y S 100), así como el gel de colágeno 50\% (control positivo - C50) y 0,9\% de solución salina (control negativo - SF) fueron utilizados en el estudio in vivo con 144 ratas Wistar adultas asignados al azar en seis grupos de tratamiento. Los animales fueron anestesiados y sometidos al procedimento quirúrgico para la extirpación de un fragmento de la región dorsal hasta la exposición de la fascia de músculo. Las lesiones fueron tratadas diariamente com cada producto de acuerdo con el grupo de análisis y evaluados para determinar la presencia de fibrina, necrosis o granulosidad en la cama y tasa de contracción. En los días 7, 14 y 21 de curación, 8 animales en cada grupo fueron sacrificados para la recolección de los fragmentos lesión utilizados en la fabricación de portaobjetos histológico. Los portaobjetos fueron teñidas con hematoxilina eosina para evaluación de infiltrado inflamatorio, la neoangiogénesis y epitelización y tiñedo picrosirius para evaluación de deposiciones y organización del colágeno. El análisis estadístico se realizó con el programa SPSS 20.0, considerando valores significativos $p \leq 0,05$. La emulsión E30 desarrollada mostró características organolépticas, extensibilidad y $\mathrm{pH}$ adecuados para aplicación tópica, apresentando estabilidad física y química durante un período de 30 días en las condiciones de almacenamiento de este estudio. Tiene capacidad antioxidativa superior el aceite puro, indicando que la redacción ha protegido a los componentes químicos del aceite. Los ensaios in vivo mostraron que la emulsión E30 ha estimulado la afluencia de neutrófilos en los 
primeros 14 días de curación y redujo el número de monocitos en el lecho de la herida a los 21 días comparado con el grupo SF. También mostró menor formación de tejido necrótico y fibrina en el lecho en comparación con otros grupos.

Palabras clave: Rosa aff rubiginosa, ceite de Rosa Mosqueta, crema de Rosa Mosqueta, cicatrización de heridas 


\section{LISTA DE ILUSTRACÕES}

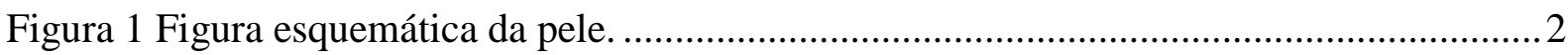

Figura 2 Fluxograma ilustrativo do processo de cicatrização. ................................................. 3

Figura 3 Representação esquemática do influxo celular no tecido lesionado ao longo do tempo de cicatrização. Fonte: Mendonça e Coutinho-Neto, 2009.

Figura 4 Triângulo de avaliação de feridas segundo o Wounds International, 2015. Adaptado:

Dowsett et al, 2015.

Figura 5 Esquema visual para avaliação de feridas segundo o Wounds International, 2015.

Adaptado: Dowsett et al, 2015.

Figura 6 Esquematização para obtenção das publicações presentes na revisão integrativa.

Brasília, 2015

Figura 7 Procedimentos para avaliação do índice de espalhabilidade. A - placa de vidro posicionada sobre papel milimetrado; $\mathrm{B}$ - placa molde com orifício central; $\mathrm{C}$ preenchimento do orifício central com a amostra da emulsão; D - visualização do volume de amostra submetido à espalhabilidade após retirada da placa molde; $\mathrm{E}$ e $\mathrm{F}$ - posicionamento das placas de vidro para avaliação da espalhabilidade, medindo-se os diâmetros horizontal e vertical da área ocupada pelo creme.

Figura 8 Demonstrativo da avaliação de cor, odor e consistência das emulsões durante os dias de análise. Brasília, 2016.

Figura 8 Demonstrativo da avaliação de cor, odor e consistência das emulsões durante os dias de análise. Brasília, 2016.

Figura 9 Evolução do índice de espalhabilidade e espalhabilidade relativa (\%) das emulsões avaliadas ao longo dos dias de armazenamento. Brasília, 2016. TesteAnova Two-Way com pós-teste de Benjamini, Krieger e Yekutieli. * diferença entre amostras A e B; \# Diferenças entre amostras A e C

Figura 10 A - Correlação de Pearson para perda de massa e espalhabilidade; B - Esquema de perda de massa das amostras ao longo dos dias de armazenamento. Brasília, 2016. Teste Anova, $\mathrm{p}=0,777$.

Figura 11 Diferenças de $\mathrm{pH}$ entre as amostras e ao longo dos dias de armazenamento. Brasília, 2016. TesteAnova Two-Way com pós-teste de Benjamini, Krieger e Yekutieli. * diferença entre amostras A e B; \# Diferenças entre amostras A e C...

Figura 12 Correlação entre perda de massa (g) e pH longo dos dias de análise. Correlação de Pearson. Brasília, 2016.

Figura 13 Correlação entre pH e esplhabilidade das amostras ao longo dos dias de análise.

Correlação de Pearson. Brasília, 2016. 
Figura 14 Capacidade antioxidativa in vitro nas emulsões e amostras de óleo ao longo dos dias de armazenamento. B - Comparação (\%) capacidade antioxidativa das emulsões e do óleo a 30\% comparado ao óleo puro, Brasília, 2016. TesteAnova Two-Way com pós-teste de Benjamini, Krieger e Yekutieli. p<00,1 entre cremes e óleos.

Figura 15 Correlação entre $\mathrm{pH}$ e capacidade antioxidante in vitro ( $\mu \mathrm{M}$ Trolox) das emulsões A (1), B (2) e C (3) ao longo dos dias de análise. p<0,001, Correlação de Pearson. Brasília, 2016.

Figura 16 Correlaçao de Pearson entre espalhabilidade $(\mathrm{mm} 2)$ e capacidade antioxidante in vitro (mM Trolox) nas amostras estudadas ao longo dos dias. Brasília, 2016.

Figura 17 A - Concentração de Betacaroteno nas amostras de óleo ao longo dos dias de armazenamento. B - Comparação da dosagem de betacaroteno no óleo a 30\% comparado ao óleo puro, Brasília, 2016. Teste Anova Two-Way com pós-teste de Benjamini, Krieger e Yekutieli, $\mathrm{p}<0,001$.

Figura 18 Apresentação de culturas em placas de petri das amostras analisadas ao longo dos dias de armazenamento, Brasília, 2016. Legenda: E30-A: emulsão 30\%, triplicata A; E30-B: emulsão 30\%, triplicata B; E30-C: emulsão 30\%, triplicata C; S100 - óleo de Rosa Mosqueta 100\%; S30 - Solução de óleo de Rosa Mosqueta 30\%.

Figura 19 Procedimentos para confecção da ferida cirúrgica: A - Tricotomia da área de confecção da ferida; B - Demarcação da lesão; C- Confecção da ferida.

Figura 20 Esquema de avaliação morfológica do leito da lesão por tipo de tecido presente.

Legenda: A - Tecido necrótico; B - Tecido fibrinoso; C - Tecido de granulação; D - Tecido de epitelização.

Figura 21 Evolução do processo de cicatrização por grupo de tratamento e tempo de eutanásia. Brasília, 2016.

Figura 22 Evolução das lesões durante o processo de cicatrização por tipo de tecido observado em leito de acordo com o grupo de tratamento. Brasília, 2016. Legenda: A - Tecido fibrinoso; B - Tecido necrótico; C - Tecido de granulação; D - Tecido de epitelização. Teste Anova Two-Way com pós-teste de Benjamini, Krieger e Yekutieli, p<0,05.

Figura 23 Proporção de ocorrência de lesões periferida entre os grupos de tratamento ao longo do tempo de cicatrização. Brasília, 2016.

Figura 24 Mediana de tempo de cicatrização por grupo de tratamento. Brasília, 2016. Teste Kruskal-Wallis, $\mathrm{p}=0,134$.

Figura 25 Taxa de retração das lesões por grupo de tratamento nos dias 7, 14 e 21 de cicatrização. Brasília, 2016. Teste de Kruskal Wallis, p=0,190.

Figura 26 Características histológicas da lesões por grupo de tratamento nos dias experimentais 7, 14 e 21, Brasília, 2016. Teste Anova Two-Way com pós-teste de Benjamini, Krieger e Yekutieli, $\mathrm{p}<0,05$. 
Figura 27 Avaliação histológica qualitativa das lesões quanto à presença de epitelização total, microabscesso, crosta, úlcera, colônias e corpo estranho. Teste Exato de Fisher, ${ }^{*} \mathrm{p}<0,001$. Brasília, 2016 63

Figura 28 Avaliação estética das lesões por tipo de tratamento. Brasília, 2016 64 


\section{LISTA DE QUADROS E GRÁFICOS}

Quadro 1 Relação de células envolvidas no processo de cicatrização e suas respectivas funções.

Quadro 2 Composição (\%) das formulações desenvolvidas à base de óleo de Rosa Mosqueta. Brasília, 2015. 30

Quadro 3 Características organolépticas das emulsões ao longo dos dias de armazenamento. Brasília, 2016

Quadro 4 Descrição dos parâmetros físico-químicos do óleo de Rosa Mosqueta segundo cromatografia gasosa.

Quadro 5 Composição do óleo de Rosa Mosqueta segundo análise em cromatografia gasosa*.

Gáfico 1 Determinação da curva-padrão de trolox. Brasília, 2016.

Gáfico 2 Correlação das concentrações do padrão de betacaroteno e área do pico, equação da reta e correlação de Pearson. Brasília, 2016. 


\section{LISTA DE TABELAS}

Tabela 1 Relação de descritores e número total de trabalhos resgatados por base de dados pesquisada. Brasília, 2015

Tabela 2 Trabalhos consultados na revisão integrativa sobre óleo de Rosa mosqueta. Brasília, 2015.

Tabela 3 Avaliação dos trabalhos consultados por nível de evidência e qualidade metodológica para estudos clínicos. Brasília, 2015. 26

Tabela 4 NMP de UFC por triplicatas da emulsão elaborada após 60 dias de armazenamento. Brasília, 2016. 46

Tabela 6 Mediana dos valores referentes aos itens avaliados por grupo de tratamento e respectivo p valor. Brasília, 2016. 


\section{LISTA DE ABREVIATURAS}

ABTS - ácido 2,2'-azinobis-3-etilbenzotiazolina-6-sulfónico

AGE - Ácidos Graxos Essenciais

AIDS - Síndrome da Imunodeficência Adquirida

Anvisa - Agência Nacional de Vigilância Sanitária.

BVS - Biblioteca Virtual em Saúde

C50 - Gel de colágeno 50\%

$\boldsymbol{C f}$ - Conforme

COMUT - Programa de Comutação Bibliográfica

DPO - Dia pós operatório

E15 - Emulsão com 15\% óleo de Rosa Mosqueta

E25 - Emulsão com 25\% de óleo de Rosa Mosqueta

E30 - Emulsão com 30\% de óleo de Rosa Mosqueta

E50 - Emulsão com 50\% de óleo de Rosa Mosqueta

EGF - fator de crescimento epidérmico

FGF - fator de crescimento derivado dos fibroblastos

HPLC - cromatografia líquida de alta eficiência

IL - Interleucina

Lilacs - Literatura Latino-Americana de Ciências da Saúde

Medline - Medical Literature Analysis and Retrieval System on Line

MMP - Metaloproteinases

O/A - emulsão óleo em água

OMS - Organização Mundial da Saúde

PDGF - Fator de crescimento derivado de plaquetas

PG - prostaglandinas

pH - potencial hidrogeniônico

PubMed - National Library of Medicine

RM - Rosa Mosqueta

rpm - rotaçao por minuto

S100 - Óleo Puro de Rosa Mosqueta

S30 - Solução com 30\% de óleo de Rosa Mosqueta

Scielo - Scientific Eletronic Library Online 
TEAC - Capacidade Antioxidante Total Equivalente ao Trolox

TGF-B - fator de crescimento de transformação beta

TNF- $\boldsymbol{\alpha}$ - fator de necrose tumoral alfa

UFC - Unidades Formadoras de Colônias

UR - Umidade relativa 


\section{LISTA DE SÍMBOLOS}

$\boldsymbol{\mu} \mathbf{L}$ - Microlitro

$\mu \mathbf{m}$ - micrômetro

$\boldsymbol{\mu M}$ - Micromolar

A - absorbância

Ci - Índice de cremeação

cm - Centímetro

d - Diâmetro

E - Espalhabilidade

g - grama

h - Horas

M - Massa

mcg - micrograma

mg - Miligrama

mL - Mililitro

nm - Nanômetro

nM - Nanomol

${ }^{\mathbf{O}} \mathbf{C}$ - Graus Celsius

p/p - Porcentagem em massa

$\mathbf{v}$ - Volume

$\mathbf{v} / \mathbf{v}$ - porcentagem em volume 


\section{SUMÁRIO}

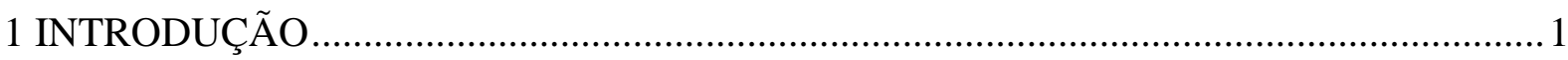

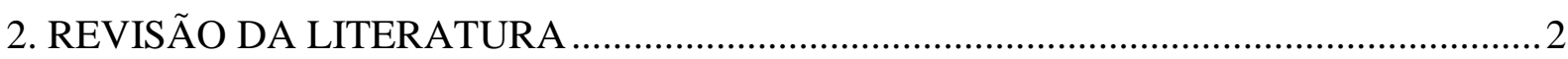

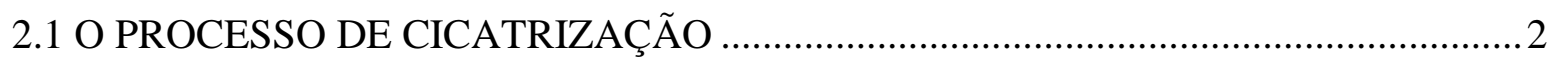

2.1.1 Hemostasia e Inflamação ……………………………………………………...

2.1.2 Fase Proliferativa......................................................................................

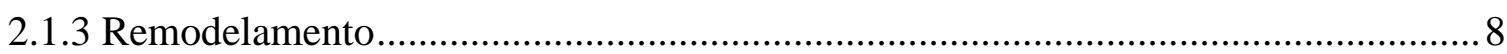

2.2 REGENERAÇÃO ANORMAL E AVALIAÇÃO DE FERIDAS …………………….... 10

2.2.1 Desequilíbrio no processo inflamatório ................................................................... 10

2.2.3 Desequilíbrio no modelamento da ferida ................................................................. 11

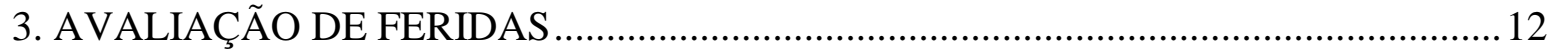

2.3 ROSA MOSQUETA: CARACTERIZAÇÃO, ASPECTOS BIOQUÍMICOS E USOS

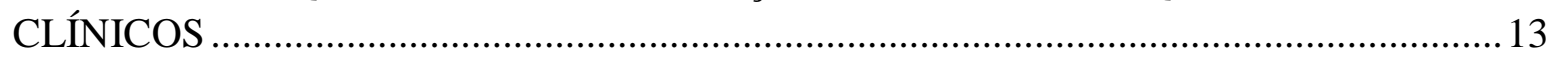

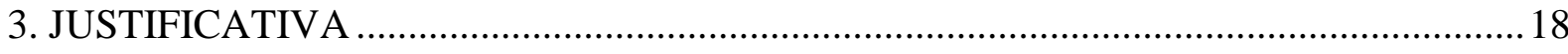

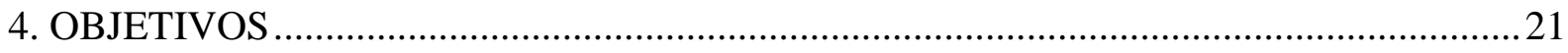

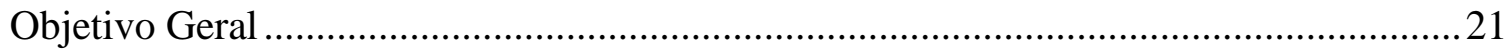

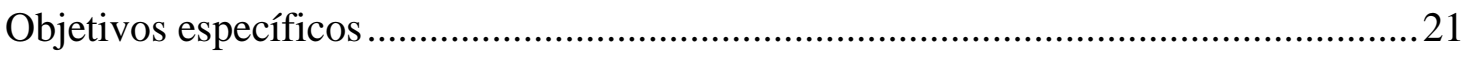

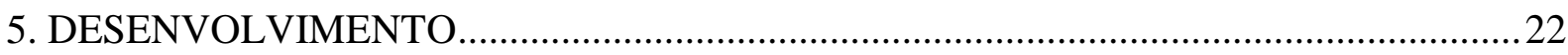

5.1 A ROSA MOSQUETA COMO POTENCIAL AGENTE CICATRIZANTE: REVISÃO

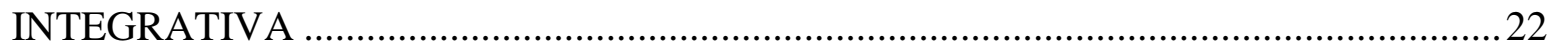

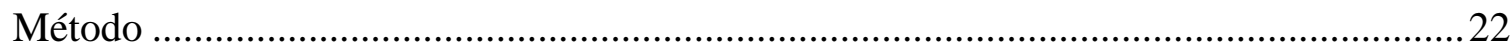

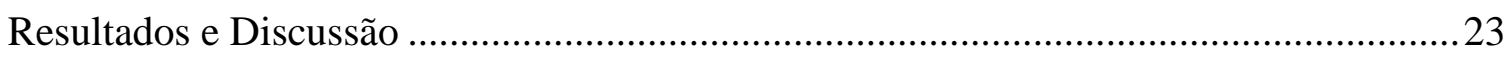

5.2 DESENVOLVIMENTO E ESTUDO DE ESTABILIDADE ACELERADA DE EMULS̃̃O À BASE DE ÓLEO DE ROSA MOSQUETA ..................................................30

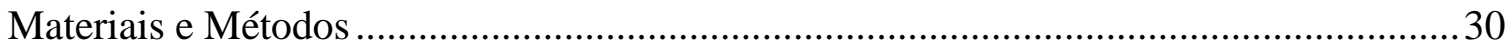

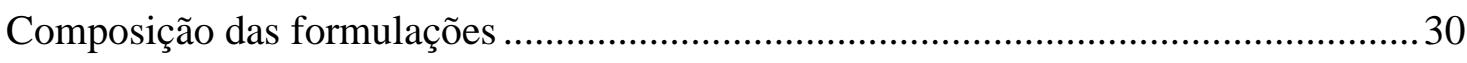

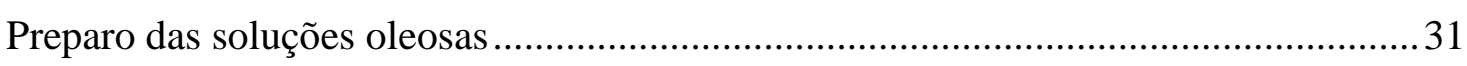

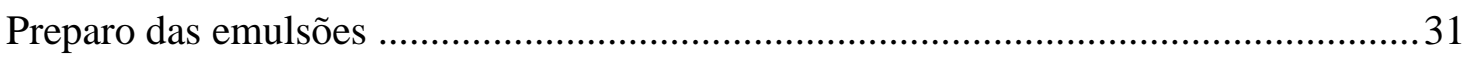

Seleção da emulsão para estudo de estabilidade acelerada ..............................................31

Análise organoléptica das formulações ................................................................... 31

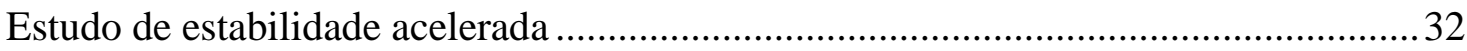

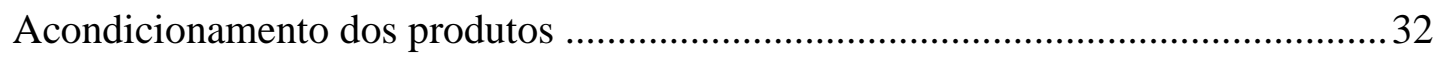




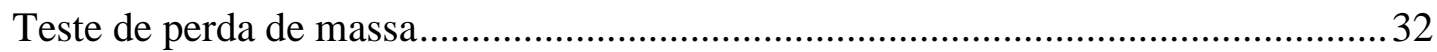

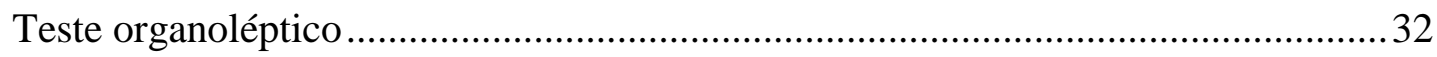

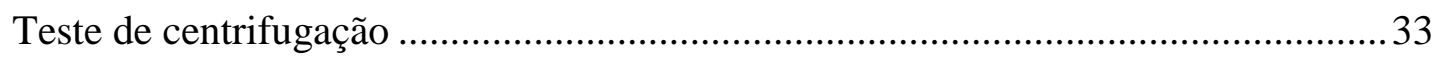

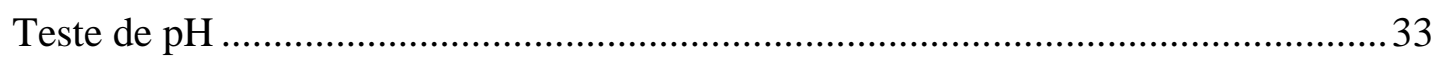

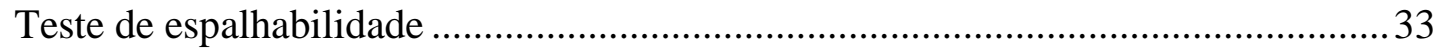

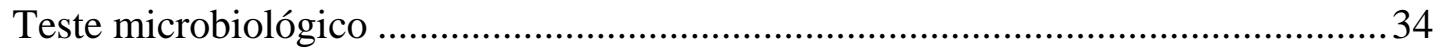

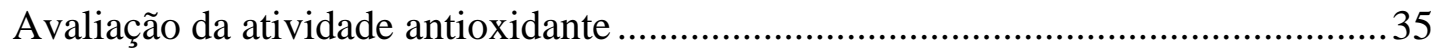

Avaliação do teor de betacaroteno .................................................................... 37

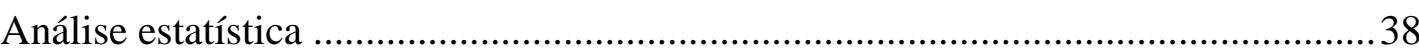

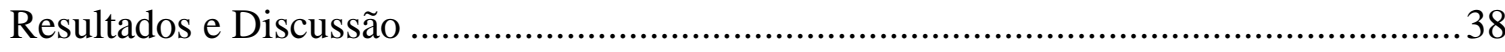

5.3 ESTUDO MORFOLÓGICO E MORFOMÉTRICO DO PROCESSO DE CICATRIZAÇÃO EM RATOS WISTAR ADULTOS TRATADOS COM CREME DE

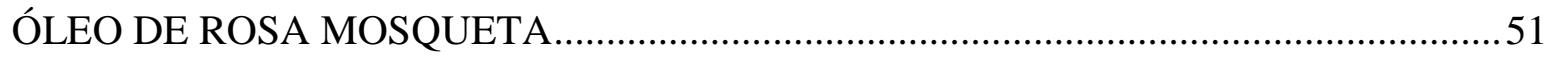

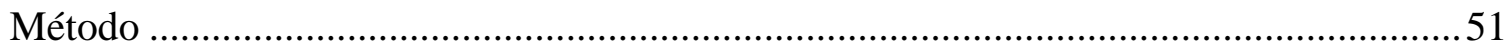

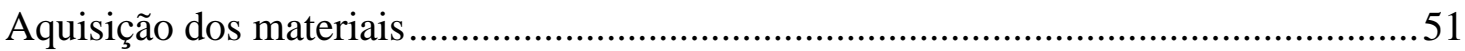

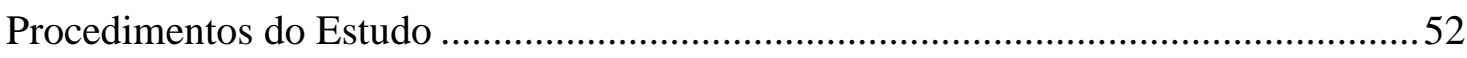

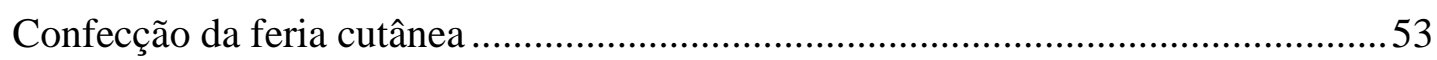

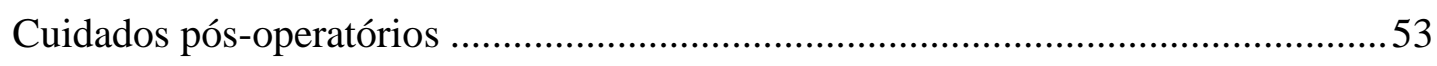

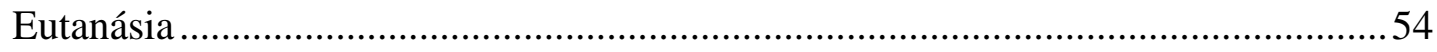

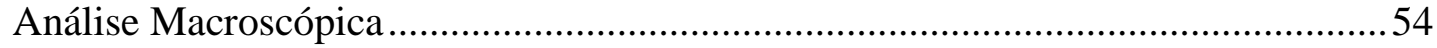

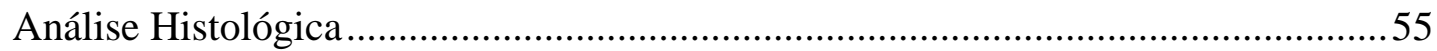

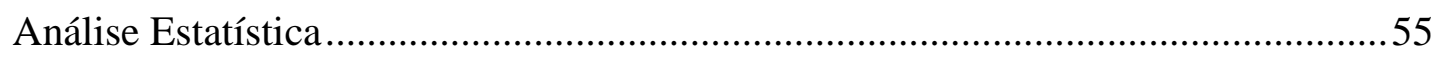

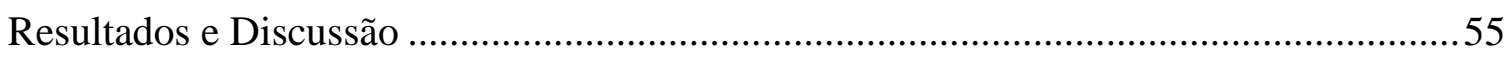

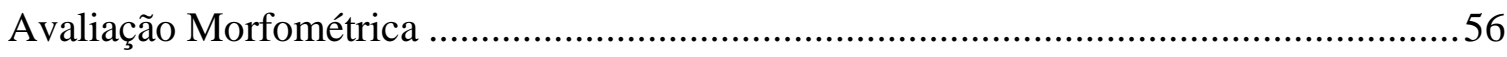

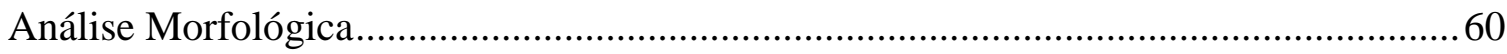

6. CONCLUSÃO

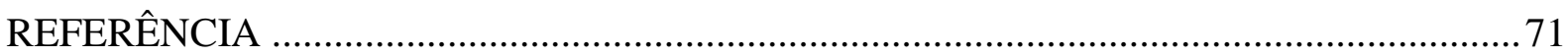




\section{INTRODUÇÃO}

De acordo com a Organização Mundial da Saúde (OMS), 80\% da população de países em desenvolvimento utiliza-se de práticas integrativas em saúde na atenção primária e, desse total, $85 \%$ fazem uso de plantas medicinais. No Brasil não existem dados exatos do número de pessoas que utilizam as plantas, mas, seguramente, essa tendência mundial também é seguida, desde o consumo da planta fresca e preparações extemporâneas, até o fitoterápico (Carvalho et al, 2007).

Uma planta que tem despertado o interesse da comunidade científica desde a década de 70 é a Rosa aff rubiginosa, também conhecida como Rosa Mosqueta, Rose Hip ou Rosa Canina, devido ao seu extenso uso popular para diversas afecções. As pesquisas com essa planta abrangem caracterização do perfil genético e bioquímico e, mais recentemente, estudos de ação de extratos e óleo fixo da planta tanto in vitro quanto in vivo (Wenzig et, 2008; Winther et al, 2013; Molezzi et al, 2002; Willich et al , 2010; Saaby et al, 2011; Fromm, 2012; Patel, 2013).

Em 2009 publicamos uma revisão de literatura sobre a Rosa Mosqueta destacando seu potencial clínico. Foi constatado que essa planta tem sido estudada por diversos pesquisadores em todos os continentes, embora estudos sobre a atividade cicatricial do óleo fixo se mostrem ainda raros e com seu uso a partir da droga in natura, sem nenhum processamento (Santos, Vieira e Kamada, 2009). Essa temática nos despertou o interesse em investigar o potencial do óleo de Rosa Mosqueta a partir de um produto farmacêutico seguro, estável e eficaz para o tratamento de feridas.

O trabalho que se segue está constituído de três estapas independentes, porém complementares. Primeiramente, apresentamos uma revisão integrativa sobre o óleo da Rosa Mosqueta no processo de cicatrização, mostrando ao leitor as evidências disponíveis na literatura científica. A essa primeira etapa, segue-se o desenvolvimento de emulsão óleo em água tendo como princípio ativo o óleo de Rosa Mosqueta e os resultados de estudo de estabilidade acelerada do produto. Por fim, essa emulsão foi utilizada em estudo de cicatrização in vivo para avaliação de sua atividade cicatrizante.

Essas três etapas, embora estejam interligadas ao objetivo geral deste trabalho, possuem estruturas independentes quanto a metodologia e resultados. 


\section{REVISÃO DA LITERATURA}

\subsection{O PROCESSO DE CICATRIZAÇÃO}

A pele é o maior órgão do corpo humano responsável pela proteção, imunidade e termorregulação do organismo. É constituída por duas camadas primárias (epiderme e derme) e uma camada de gordura subcutânea (Irion, 2012) (cf. Fig. 1).

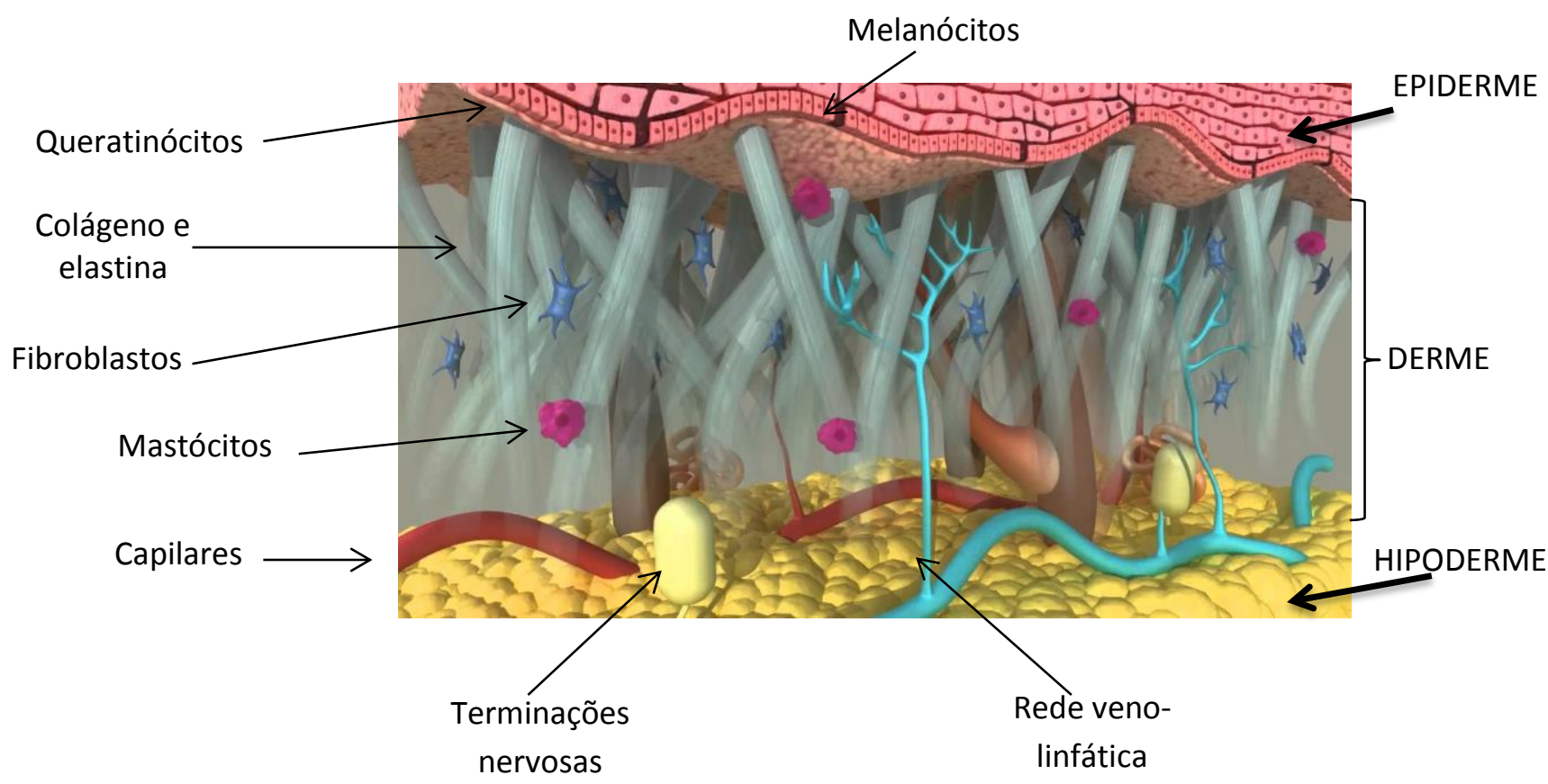

Figura 1 Figura esquemática da pele. Fonte: NovidermPortugal.

Sua capacidade regenerativa abrange uma complexa rede celular e bioquímica comum a todas as lesões e cuja intensidade e duração irão depender da extensão do dano celular (Young \& MaCnaught, 2011). Esses eventos podem ser promovidos ou perturbados por uma intervenção externa.

O termo lesão é definido como a ruptura da estrutura anatômica normal da pele e, principalmente, de sua função (Diegelman, 1997). A reparação tecidual é um mecanismo de sobrevivência no qual o tecido danificado é degradado e substituído gradualmente por células e tecido novo até que a integridade da pele seja restaurada. A reparação tecidual ocorre tanto pela regeneração espontânea da epiderme como pela reparação do tecido conectivo, o que dependerá da extensão e da profundidade da lesão, se o trauma é restrito a partes moles, ou causado cirurgicamente. Em injúrias menores envolvendo a epiderme em que a camada basal 
não sofre dano, células regenerativas migram do tecido profundo para o mais superficial, finalizando a epitelização no período de 7 a 10 dias. No entanto, nas lesões em que ocorre perda de tecido dérmico e anexos (glândulas sebáceas, glândulas sudoríparas e folículos pilosos) a reepitelização não ocorre até que toda a área da lesão seja preenchida por tecido conectivo (Beldon, 2010).

O processo de cicatrização abrange uma sequência fixa de eventos que tornam-se mais evidentes quando ocorre lesão da espessura total da pele (epiderme e derme), e do tecido subcutâneo. A partir da agressão tecidual, é desencadeada uma perfeita e coordenada cascata de eventos celulares, bioquímicos e moleculares que interagem para que ocorra regeneração tecidual (Roubelakis, 2014). O processo de cicatrização é dividido em quatro fases: hemostasia, inflamação, proliferação e remodelamento ( $c f$. Fig. 2). Ao longo dessas fases, é ativada uma sequência ordenada e superposta de quatro processos descritos a seguir (Irion, 2012).

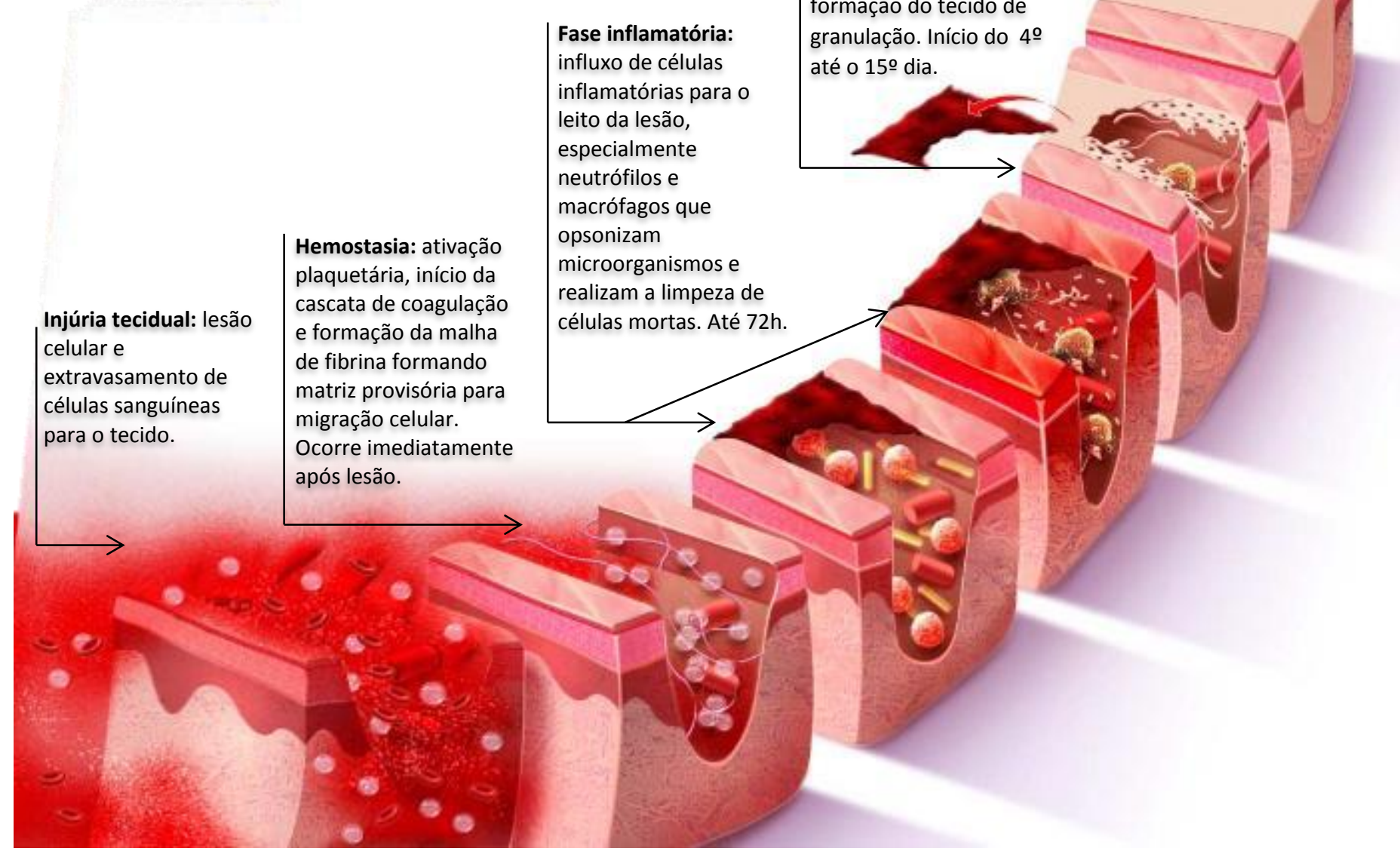

Fase Proliferativa:

liberação de fatores de crescimento que estimulam proliferação e migração de fibroblastos, neoangiogênese $e$ formação do tecido de granulação. Início do 4 até o 15임. inflamatórias para o leito da lesão, especialment realizam a limpeza de células mortas. Até $72 \mathrm{~h}$.
Remodelamento:

migração e diferenciação de queratinócitos, substituição do colágeno II por colágeno I com intensa ação das MMP's. Ocorre por meses.

Figura 2 Fluxograma ilustrativo do processo de cicatrização. Fonte: Ebah 


\subsubsection{Hemostasia e Inflamação}

Assim que ocorre a lesão tecidual, componentes sanguíneos entram em contato com o colágeno e outros elementos da matriz extracelular do epitélio lesionado, o que provoca rápida ativação plaquetária e inicia a cascata de coagulação. Esse processo resulta em formação de moléculas de fibrina insolúvel responsáveis pela hemostasia dos capilares lesionados e liberação de grânulos presentes nas plaquetas contendo fator de crescimento plaquetário, fator de crescimento de transformação beta (TGF- $\beta$ ), fator de crescimento derivado dos fibroblastos (FGF), fator de crescimento epidérmico (EGF), prostaglandinas e tromboxanas (Roubelakis et al, 2014). Esse agrupamento de plaquetas, proteínas da matriz extracelular e do sistema de coagulação forma uma matriz provisória que serve de alicerce para a migração celular, tanto a partir da circulação como das regiões adjacentes (Balbino, 2005).

Tais substâncias no tecido lesionado, juntamente com a ativação do sistema complemento, iniciam o processo inflamatório com recrutamento de neutrófilos e macrófagos. Os neutrófilos são as primeiras células de defesa a migrarem para o tecido nas $24 \mathrm{~h}$ iniciais da ocorrência da ferida e podem permanecer no local por horas ou dias até que o tecido esteja livre de bactérias e células mortas (Campos, 2007). Tanto neutrófilos quanto macrófagos aumentam a permeabilidade vascular provocando extravasamento de plasma e proteínas, e o edema associados à inflamação. São responsáveis pela opsonização de bactérias, apresentação aos leucócitos recrutados e remoção de células mortas. Sendo células de defesa de ação inespecífica, o recrutamento de neutrófilos também pode resultar em dano tecidual devido à liberação de enzimas (elastases e colagenases) e radicais livres (Irion, 2012).

O aparecimento de neutrófilos fagocitados por macrófagos marcam o fim da fase inflamatória, que dura cerca de 72h. Entretanto, fatores externos podem manter o influxo de neutrófilos por mais tempo, aumentando a lesão tecidual, como contaminação, corpo estranho ou tratamento agressivo da ferida (Godoy \& Prado, 2005). A inflamação em feridas agudas dura em geral três a sete dias, portanto, um período mais longo de inflamação é preditivo de regeneração lenta.

Iniciando o processo de transição para a próxima fase, os macrófagos começam a invadir a área da lesão do segundo ao quinto dia e assume um papel crítico na indução do processo de reparo. Esta é a célula mais eficiente na eliminação de microorganismos pela fagocitose, inclusive de neutrófilos que perderam a função, além de atuar como elo entre o sistema imune inato e o adaptativo (Balbino, 2005). Os macrófagos também são necessários 
tanto para a iniciação quanto para a propagação do tecido de granulação por meio da liberação de substâncias como prostaglandinas (PG) e leucotrienos, quimioatrativos para a reparação celular, fatores de crescimento, mediadores peptídicos e enzimas relacionadas ao reparo (colagenases e matriz de metaloproteases). A transição da fase inflamatória para a fase proliferativa depende da efetividade dos macrófagos na retirada dos fragmentos de uma área e na liberação de fatores de crescimento (Irion, 2012; Balbino, 2005).

\subsubsection{Fase Proliferativa}

Esta fase tem início ao redor do $4^{\circ}$ dia após a lesão, se estende aproximadamente até o término da segunda semana e é constituída por quatro etapas fundamentais: epitelização, angiogênense, formação de tecido de granulação e deposição de colágeno. A epitelização tem início já nas primeiras $24 \mathrm{~h}$, com células epiteliais migrando da periferia para o centro do tecido lesionado a fim de restabelecer as camadas epiteliais, embora não possa ser observável até o $3^{\text {a }}$ dia pós lesão (Campos, 2007, Irion, 2012). A presença local de macrófagos derivados de monócitos e a produção e liberação de mediadores químicos produzidos por eles intensificam a migração e ativação de fibroblastos (Balbino, 2005).

A formação de tecido de granulação pelos fibroblastos, macrófagos, vasos neoformados e células endoteliais se inicia em três a cinco dias, concomitante à reepitelização (Irion, 2012). A formação desse tecido depende do processo de fibroplasia, no qual ocorre o acúmulo de macrófagos que estimulam o crescimento interno de fibroblastos que, por sua vez, irão produzir colágeno local e substituir a matriz extracelular por um tecido conjuntivo mais forte e elástico (Balbino, 2005).

Os fibroblastos dos tecidos vizinhos migram para a ferida e são ativados a sair de seu estado de quiescência pelo PDGF. Esse movimento é direcionado pela orientação da matriz provisória, um fenômeno conhecido como 'guia de contato', facilitado quando a composição da matriz extracelular é mais rica em gel de fibronectina do que colágeno (McDougall, 2006) e orientado pelo gradiente de substâncias quimioatraentes. Em seguida, TGF - $\beta$ é liberado e estimula os fibroblastos a produzirem colágeno tipo $\mathrm{I}$ e a se diferenciarem em miofibroblastos, promovendo a contração da ferida (Campos, 2007). Fator importante nesse processo é a formação concomitante de novos vasos sanguíneos, influenciados tanto por fatores de crescimento, especialmente o fator de necrose tumoral alfa (TNF - $\alpha$ ) quanto pela baixa tensão de oxigênio no centro da ferida, que irão garantir suporte nutricional ao novo tecido (Williamson \& Harding 2004; Balbino, 2005). 
Quadro 1 Relação de células envolvidas no processo de cicatrização e suas respectivas funções.

\begin{tabular}{|c|c|c|}
\hline Tipo celular & Tempo de ação & Função \\
\hline \multirow[t]{3}{*}{ Plaquetas } & Segundos & Formação de trombo \\
\hline & & $\begin{array}{l}\text { Ativação da cascata de } \\
\text { coagulação }\end{array}$ \\
\hline & & $\begin{array}{l}\text { Liberação de mediadores } \\
\text { inflamatórios (PDGF, TGF- } \beta \text {, } \\
\text { FGF, EGF, histamina, } \\
\text { serotonina, } \\
\text { prostaglandinas, tromboxana). }\end{array}$ \\
\hline \multirow[t]{4}{*}{ Neutrófilos } & Pico em 24h & Fagocitose de bactérias \\
\hline & & Desbridamento \\
\hline & & $\begin{array}{l}\text { Liberação de enzimas } \\
\text { proteolíticas }\end{array}$ \\
\hline & & $\begin{array}{l}\text { Produção de radicais de oxigênio } \\
\text { Aumento da permeabilidade } \\
\text { vascular }\end{array}$ \\
\hline \multirow[t]{3}{*}{ Queratinócitos } & Em $8 \mathrm{~h}$ & $\begin{array}{l}\text { Liberação de mediadores } \\
\text { inflamatórios }\end{array}$ \\
\hline & & $\begin{array}{l}\text { Estímulo à migração de } \\
\text { queratinócitos periféricos }\end{array}$ \\
\hline & & Neovascularização \\
\hline \multirow[t]{2}{*}{ Linfócitos } & $72-120 \mathrm{~h}$ & Regula a fase proliferativa \\
\hline & & Deposição de colágeno \\
\hline \multirow[t]{5}{*}{ Fibroblastos } & $120 \mathrm{~h}$ & Síntese do tecido de granulação \\
\hline & & Síntese de colágeno \\
\hline & & $\begin{array}{l}\text { Produção dos componentes da } \\
\text { matriz extracelular }\end{array}$ \\
\hline & & Liberação de proteases \\
\hline & & $\begin{array}{l}\text { Liberação de mediadores } \\
\text { inflamatórios }\end{array}$ \\
\hline
\end{tabular}

Fonte adaptada: Young and McNaught, 2011.

O tecido de granulação é composto por um aglomerado de células e vasos neoformados sustentados por uma matriz frouxa de fibronectina, ácido hialurônico e colágeno tipos I e III. 
Esse é um tecido edematoso, com muitos espaços vazios devido à imaturidade dos vasos que são exudativos e sangram facilmente. A neovascularização é o que confere a coloração róseoavermelhado brilhante do tecido de granulação saudável (Williamson \& Harding 2004; Irion, 2012).

Ao mesmo tempo, os fibroblastos e macrófagos na região produzem fibronectina, que irá auxiliar na fixação das próprias células. Outra substância produzida em grande quantidade neste segundo estágio é o ácido hialurônico, um polissacarídeo glicosaminoglicano não sulfatado com facilidade de se ligar à água, que auxilia na resistência do tecido à compressão. Tais substâncias na matriz propiciam um microambiente eficiente para a movimentação das células necessárias nessa etapa. À medida que a maturação da ferida avança, a concentração de ácido hialurônico diminui e a síntese de proteoglicanos ou glicosaminoglicanos sulfatados aumenta, o que favorece a fixação e imobilidade das células e a consequente diferenciação para fenótipos maduros (Balbino, 2005).

$\mathrm{Na}$ etapa final da fase proliferativa, os vasos neoformados assumem características de capilares e os fibroblastos começam a desenvolver atividades de síntese protéica, passando a secretar grandes quantidades de colágeno. Este, aos poucos, substitui os proteoglicanos e a fibronectina até se tornar o principal componente da cicatriz em formação. Nessa fase, a tensão de oxigênio deve aumentar no leito da ferida, promovendo a hidroxilação dos resíduos de prolina e lisina nas cadeias peptídicas do colágeno montadas no citoplasma dos fibroblastos. A hidroxiprolina produzida pelos fibroblastos agrega-se em uma tríplice hélice formando pró-colágeno que é liberado para o espaço extracelular onde serão processadas e transformadas em tropocolágeno. Essas moléculas se agregam, formando uma rede inicial de fibras de colágeno desorganizada, proporcionando resistência limitada à tração da ferida (Irion, 2012; Balbino, 2005).

É nessa fase de fixação dos fibroblastos e produção de colágeno que a contração da ferida alcança sua eficiência máxima. Isso ocorre devido à mudança de fenótipo dos fibroblastos das margens da ferida para miofibroblastos, que começam a exibir características funcionais semelhantes às células do músculo liso. Essas células são encontradas alinhadas ao redor de depósitos da nova matriz extracelular, fazendo uniões célula a célula e gerando força de tensão. O ressecamento da crosta superficial da ferida também auxilia no processo de contração, pois a desidratação leva à redução do tamanho da lesão e arrasta o tecido a ela aderido (Balbino, 2005).

A liberação de IL-1 e do fator de crescimento epidérmico estimula a formação de novas células nas bordas da ferida, que aderem ao tecido de granulação abaixo e migram por sobre 
as células por epibolia, processo descrito como "pular carniça", até chegar à margem da ferida que avança sobre o tecido de granulação. Ao mesmo tempo, a perda da inibição de contato no leito da lesão estimula a alteração fenotípica de queratinócitos das bordas livres, folículos pilosos e glândulas sudoríparas, que se proliferam e perdem seus desmossomos e os filamentos internos de queratina, migrando para o centro da lesão. Esses queratinócitos desenvolvem filamentos de actina e mobilidade, perdem a polaridade apical/basal e estendem pseudópodes na direção da ferida, onde produzirão uma matriz provisória de fibrina, fibronectina e colágeno tipo V caso a membrana basal esteja danificada (Irion, 2012). Esse processo de migração de queratinócitos somente se inicia quando o tecido de granulação alcança o nível da epiderme, oferecendo um substrato adequado para a migração celular. As células voltam ao fenótipo normal quando a ferida é coberta, e os queratinócitos são novamente contidos pelo restabelecimento dos desmossomos (Balbino, 2005).

Ao final desta etapa, o leito da ferida está totalmente preenchido por tecido de granulação, a circulação é restabelecida pela neovascularização e a rede linfática está passando por regeneração. A aparência de cicatriz começa a se estabelecer pelo acúmulo de massa fibrosa (Balbino, 2005).

\subsubsection{Remodelamento}

O processo de remodelamento leva meses ou até anos para se completar (Beldon, 2010). A matriz extracelular sofre modificações contínuas até que esteja estável. Sendo assim, a matriz extracelular é diferente na periferia e no centro de uma ferida. A pele reepitelizada tem uma força tênsil de $15 \%$ da pele normal, alcançando aproximadamente $80 \%$ quando o remodelamento está completo (Irion, 2012; Beldon, 2010).

É nessa fase que a deposição de colágeno ocorre de maneira mais organizada, substituindo o colágeno produzido inicialmente, que é mais fino (colágeno tipo III), por um colágeno mais espesso (Tipo I) presente na pele normal com orientação paralela à pele, organizado ao longo das linhas de tensão. Essas mudanças resultam em aumento da força tênsil da ferida. Finalmente, influenciados por citoquinas e fatores de crescimento, os fibroblastos migrantes organizam as fibras de colágenos produzidas até alcançar a estrutura dérmica conhecida (Campos, 2007; McDougall, 2006).

O processo de reorganização matricial da cicatriz ocorre por meio de colagenases secretadas por fibroblastos e leucócitos, que promovem a lise da matriz antiga e sucessiva reorganização das fibras de colágeno. Os fibroblastos produzem colágeno a uma taxa 
constante e degradam o colágeno antigo a uma taxa proporcional à quantidade de colágeno já presente (McDougall, 2006), rearranjando as fibras de colágeno de acordo com a organização das fibras do tecido conjuntivo adjacente. A cicatrização tem sucesso quando há equilíbrio entre a síntese da nova matriz e a lise da matriz antiga (Campos, 2007).

Os eosinófilos aparecem nas últimas fases da reparação e acredita-se estarem relacionados à produção de fatores de crescimento. Após o fechamento da lesão, os linfócitos constituem as células de defesa mais abundantes em feridas humanas, que além de exercerem ação imune, produzem fatores de crescimento. Ao final da etapa de remodelamento, os anexos da pele, como folículos pilosos e glândulas sofrem regeneração limitada e a cicatriz permanece pálida por regeneração deficiente de melanócitos. Além disso, a cicatriz é hipovascularizada devido ao desaparecimento dos neocapilares (Balbino, 2005).

A figura 3 abaixo mostra o influxo de células durante o processo de reparação tecidual de acordo com as fases e dias de cicatrização.

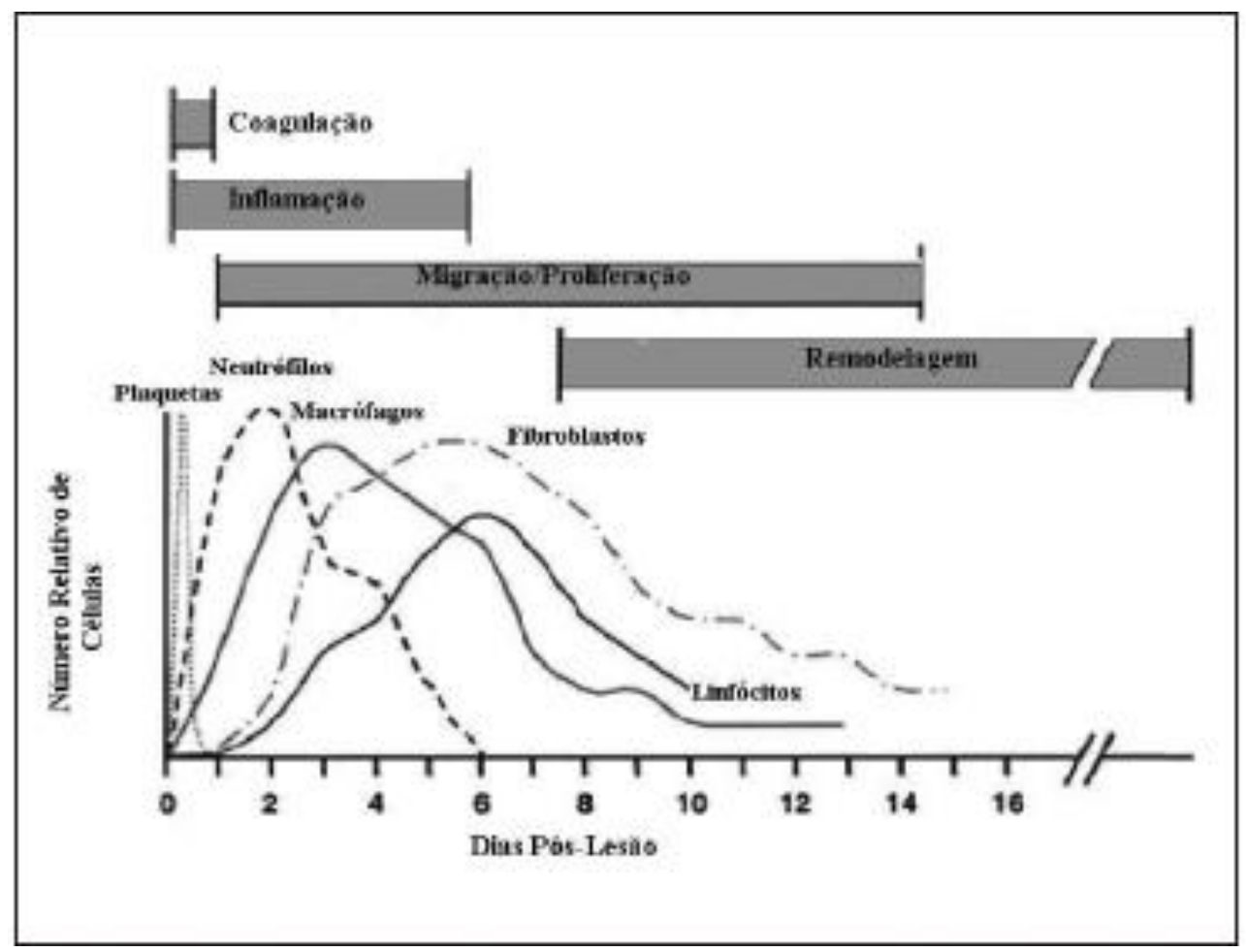

Figura 3 Representação esquemática do influxo celular no tecido lesionado ao longo do tempo de cicatrização. Fonte: Mendonça e Coutinho-Neto, 2009. 


\subsection{REGENERAÇÃO ANORMAL E AVALIAÇÃO DE FERIDAS}

A expressão regeneração anormal de feridas descreve a inexistência de evolução cronológica adequada da regeneração de uma ferida (Irion, 2012). A regeneração anormal pode ser desencadeada por: fatores sistêmicos - desnutrição, desidratação, doenças crônicas (diabetes, hipertensão, AIDS), tabagismo, etilismo, doenças imunológicas, envelhecimento, fatores genéticos; fatores locais - redução de oxigenação local, infecção, corpo estranho, edema, compressão, atrito; fatores iatrogênicos - medicamentos, cirurgias, intervenções inadequadas (Young \& McNaught, 2011; Irion, 2012).

No geral, independente do fator, o processo de cicatrização pode sofrer falhas nas fases de inflamação, reepitelização, formação do tecido de granulação ou no remodelamento, acarretando atrasos no processo de cicatrização ou maior dano celular.

\subsubsection{Desequilíbrio no processo inflamatório}

Em feridas onde a fase inflamatória se prolonga além tempo esperado, seja por fatores externos ou sistêmicos, o processo de cicatrização não consegue evoluir para a fase proliferativa responsável pela formação do tecido estrutural de vasos neoformados, malha de fibroblastos e tecido conjuntivo. Mais e mais células inflamatórias continuam a chegar ao sítio lesionado com consequente degranulação e liberação de enzimas e radicais livres. As células de defesa, especialmente neutrófilos, mantém a fagocitose de células e produtos locais acarretando maior dano tecidual. Como consequência, percebe-se uma ferida pouco oxigenada, apresentando tecido necrótico ou fibrinoso, drenando secreção de moderada a máxima. Esse líquido inflamatório, por sua vez, ao entrar em contato com as células sadias inibe o crescimento de células endoteliais, queratinócitos e fibroblastos. Caracteriza-se, ainda, por ser um líquido rico em metaloproteinases da matriz (MMP) e níveis baixos de fatores de crescimento. Além disso, a umidade excessiva provoca maceração da pele adjacente e consequente lesão tecidual (Irion, 2012).

Por outro lado, deficiência no processo inflamatório também irá resultar em atraso na cicatrização por incapacidade em preparar adequadamente o local da ferida e iniciar o processo de regeneração. A falta do processo inflamatório resulta em deficiência de fatores de crescimento e de circulação sanguínea. Dessa forma, células responsáveis pela limpeza local e remoção de material necrótico não conseguem chegar ao local lesionado, o que resulta em uma barreira física contra a angiogênese necessária ao reparo tecidual. Essa lesão se 
apresentará, de forma geral, ressecada e recoberta por escara, em geral rígida e negra, com pouca ou nenhuma secreção, dificultando a proliferação e migração celular (Irion, 2012).

\subsubsection{Desequilíbrio entre granulação e reepitelização}

Em circunstâncias normais, o tecido de granulação preenche a ferida a partir da base e das bordas da lesão. Quando o tecido de granulação alcança a altura da epiderme circunvizinha, o tecido de epitelização começa a migrar através do tecido de granulação. Em alguns, casos, no entanto, a epitelização pode ocorrer mais rapidamente que a granulação, de forma que a ferida fechada exibe uma depressão nos casos mais leves. Quando esse descompasso é mais intenso, pode ocorrer o fechamento da lesão sem o completo preenchimento da ferida, fazendo com que bactérias e tecido desvitalizado fiquem encarcerados no tecido subcutâneo com probabilidade de ocorrência de infecção ou lojas (Irion, 2012).

Já a hipergranulação ocorre quando há crescimento excessivo no leito da ferida, fazendo com que a base da mesma exceda a altura da pele ao seu redor, o que resulta em uma cicatriz pouco estética (Irion, 2012).

Os fibroblastos são os responsáveis pela produção de colágeno para a formação do tecido conectivo na reparação tecidual. Em tecido epitelial normal, o colágeno é responsável por conferir força, integridade e estrutura. Entretanto, se quantidades excessivas de colágeno são depositadas no local da lesão, ocorre perda ou alteração da estrutura do tecido cicatricial, processo denominado fibrose. Por outro lado, se quantidades insuficientes de colágeno são produzidas, não há tecido suficiente para deposição no sítio da ferida e a cicatrização dificilmente se completará (Diegelman, 1997).

\subsubsection{Desequilíbrio no modelamento da ferida}

A transição do tecido de granulação para a epitelização e formação da cicatriz envolve reorganização e maturação das fibras de colágeno. Na cicatrização normal, o processo de síntese e quebra de colágeno pode durar até três meses após a injúria pela ação de metaloproteinases da matriz produzidas pelos macrófagos, células endoteliais e fibroblastos. Essas enzimas proteolíticas quebram o colágeno produzido pelos fibroblastos em um delicado processo que exige equilíbrio entre síntese e degradação de colágeno até completa restauração tecidual. A aparência da cicatriz sofre modificação por até dois anos após a injúria pela 
manutenção desse delicado equilíbrio, o que é denominado modelamento (Williamson \& Harding, 2004).

Alterações ou desequilíbrio nesse processo resultam em cicatriz de aspecto grosseiro como queloide ou cicatriz hipertrófica. No caso do queloide, há crescimento do tecido cicatricial para além das bordas da lesão. Essa cicatriz permanece altamente irrigada, o que lhe confere sua coloração escurecida e está relacionada a fatores genéticos (Young \& McNaught, 2004). Já a cicatriz hipertrófica é caracterizada por elevação acima do nível da pele circundante, mas se restringem à borda da lesão e com o passar do tempo, diminuem em altura, tamanho e vascularidade, tornando-se planas, brancas e avasculares em alguns meses (Irion, 2011).

\section{AVALIAÇÃO DE FERIDAS}

A avaliação do aspecto da lesão pode dar subsídios para a identificação de possíveis distúrbios no processo de cicatrização a fim de estabelecer o manejo adequado ou possibilitar estudos sobre a evolução do processo de reparo tecidual (Lazarus, 1994).

A avaliação morfométrica da ferida consiste em observação física e monitoramento do aspecto da lesão (Dowsett, 2015). Cinco aspectos críticos devem ser observados: coloração, odor, secreção, extensão e pele circunvizinha (Irion, 2012, Saar \& Lima, 2010). O Wounds International (2015) estabelece um triângulo de avaliação que envolve o leito da ferida, bordas e pele circunvizinha ( $c f$. Fig. 4$)$.

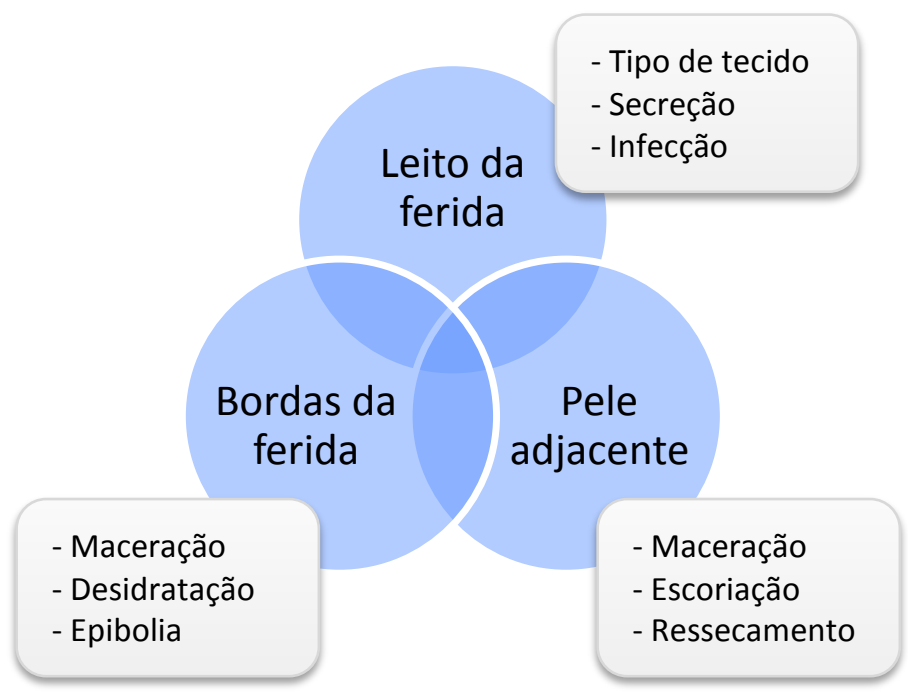

Figura 4 Triângulo de avaliação de feridas segundo o Wounds International, 2015. Adaptado: Dowsett et al, 2015. 
A avaliação do leito da lesão envolve a descrição da coloração, dos tipos de tecidos encontrados ( $c f$. Fig. 5) bem como sua porcentagem e a presença e tipo de exsudato (Lazarus, 1994).

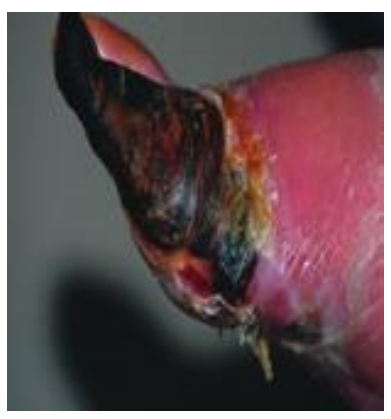

Tecido necrótico

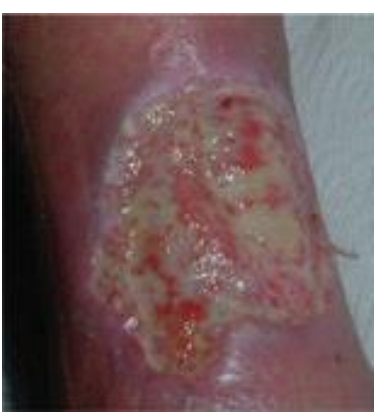

Fibrina

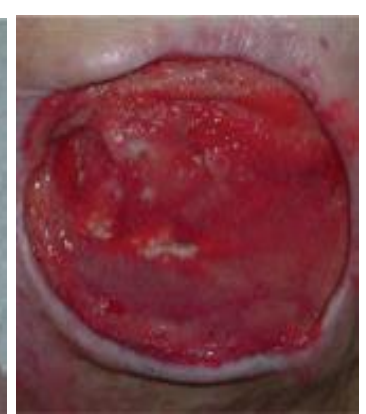

Tecido de granulação

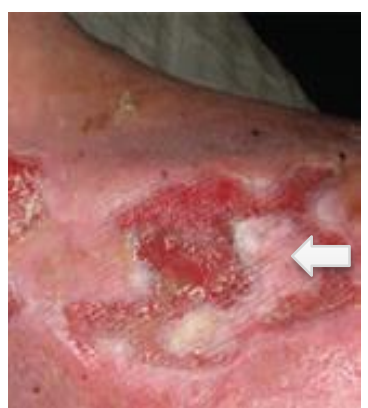

Tecido de epitelização

Figura 5 Esquema visual para avaliação de feridas segundo o Wounds International, 2015. Adaptado: Dowsett et al, 2015.

Outro importante critério para avaliação da evolução de feridas corresponde à taxa de retração, calculada a partir do dimensionamento da área da lesão, que pode ser realizado por meio de softwers que utilizam imagens digitais (Reis et al, 2012), régua milimetrada ou paquímetros digitais (Oliveira et al, 2005). O cálculo da área de lesão pode ser obtido traçando-se duas linhas perpendiculares tomando-se como referência os pontos mais extensos do comprimento e da largura da ferida (Saar \& Lima, 2010). Esse método mostra-se eficaz principalmente em feridas relativamente regulares (Dealey, 2008).

\subsection{ROSA MOSQUETA: CARACTERIZAÇÃO, ASPECTOS BIOQUÍMICOS E} USOS CLÍNICOS

A família das Rosáceas compreende mais de 3000 espécies e 100 gêneros utilizadas nas mais diversas indústrias: perfumaria, cosmética e farmacêutica (Pareja, 1996; Valdebenito, 2003). Nos últimos anos, possivelmente uma das plantas mais estudadas tem sido a Rosa Mosqueta ( $R$. aff. Rubiginosa; R. eglentaria; R. Canina) devido às múltiplas aplicações da flor, do fruto e da semente, assim como seus inúmeros derivados, cujos efeitos farmacológicos têm sido comprovados por investigadores de diversos países. 
Rosa Mosqueta (Rosa aff rubiginosa) é uma espécie de rosa selvagem que se desenvolve bem em terrenos degradados, em regiões de temperaturas e umidade amenas (Valdebenito, 2003). É originária da Europa Central, Polônia, Bálcãs, Hungria, Rússia e Cáucaso, sendo também encontrada em abundância na África e Índia (Valdebenito, 2003). Na América do Sul, foi introduzida ainda no período colonial, tornando-se bastante abundante no sul do Chile onde é muito comum na zona compreendida entre a décima primeira e a décima segunda região, especialmente na província de Concepción. No Peru, cresce nas regiões do Cuzco, Arequipa e Apurimac, compreendidos entre a sétima e a décima primeira região. Também é abundante no sul da Argentina e nos Estados do Missouri, Nebraska e Wyoming nos Estados Unidos (Pareja, 1996; Valdebenito, 2003).

Na Antigüidade, a raiz da Rosa Mosqueta era usada para eliminar cálculos renais. Já os romanos empregavam a flor da planta para acabar com a embriaguez e na preparação de perfumes (Plantaservas, 2006). Na medicina tradicional, as pétalas das flores têm sido utilizadas desde a época precolombiana em infusões para o tratamento de processos inflamatórios da garganta, assaduras e infecções (Pareja, 1996).

Os frutos dessa planta apresentam uma alta concentração de ácido ascórbico ou vitamina C (Kazankaya et al, 2005; Dogan \& Kazankaya, 2006), motivo pelo qual o chá das cascas dos frutos é empregado no tratamento e prevenção de resfriados (Valdebenito, 2003; ). O fruto ainda contém pigmentos carotenoides (Andersson, 2011; Cunja, 2015) dos quais se pode citar o licopeno, beta-caroteno, alfa-caroteno e a alfa-criptoxantina, que possui caráter de pró-vitamina A, favorecedora de inúmeras funções fisiológicas. É rico em ferro, cálcio, fósforo e flavonóides, o que justifica sua importância nutricional (Pareja, Valdebenito, PlantasMed). A ação antioxidante e antiinflamatória dos flavonóides já tem sido bastante investigado e comprovado (Kanashiro et al, 2004).

Revisões de literatura (Patel, 2013; Orhan e Hartevioglu, 2013) apontam evidências de que o extrato da Rosa Mosqueta tem propriedades anti-inflamatórias, cardioprotetora, imunomodulatória (Saaby, 2011), protetora gástrica (Latanzzio, 2011), hipoglicemiante (Andersson et al, 2011), antimicrobiana (Chrubasik et al, 2008), antidiarreica (Orhan, 2013), além da possibilidade de aplicações cutâneas. Essas propriedades estariam relacionadas aos compostos fenólicos, especialmente proantocianidinas.

Tumbas e sua equipe (2012) verificaram, in vitro, atividade contra radicais livres de extrato puro do fruto de Rosa Mosqueta. Conferem esse achado à presença de compostos fenólicos, flavonoides e vitamina $\mathrm{C}$, capazes de reduzir a atividade de radicais hidroxil e 
ânion superóxido. Em outro estudo (2012), os mesmos autores verificaram com esse extrato, inibição de crescimento celular de células cancerígenas também in vitro.

Daels-Rakotoarison et al (2002) e Larsen et al (2003) isolaram um galactopeptídeo do extrato de sementes de Rosa Mosqueta capaz de inibir, in vitro, a quimiotaxia de neutrófilos de sangue periférico humano, enquanto Kharazmi \& Winther (2005) demonstraram, também, uma redução de parâmetros inflamatórios in vivo. Em ensaio não clínico randomizado, Hakansson (2006) e sua equipe demonstraram menor inflamação e colonização do tecido colônico injuriado por isquemia e reperfusão em ratos, com o uso de um preparado de Rosa Mosqueta, reduzindo a peroxidação lipídica nesses tecidos.

Por seu potencial imunomodulador, um extrato de Rosa Mosqueta tem sido empregado no tratamento de pacientes com osteoartrite (Orhan \& Hartevioglu, 2013), melhorando os parâmetros de dores articulares e reduzindo o uso de medicações analgésicas (Chrubasik, Duke e Chrubasik, 2006; Winter et al, 2013). Estudos também observaram redução de parâmetros inflamatórios nesses pacientes (Warholm et al, 2003; Willich et al, 2010; Winter et al, 2013).

Da semente é possível extrair um óleo concentrado rico em ácidos graxos essenciais insaturados (Szentmihálvi et al, 2002) em concentração de cerca de $80 \%$, que correspondem ao ácido linoleico (entre 43 e 49\%), ácido alfa-linolênico (entre 32 e 38\%) e ácido oleico (entre 14 e 16\%) (Eggers et al, 2000; Machmudah et al, 2008; Roman et al, 2013). Quantidades menores de ácidos graxos saturados também estão presentes: ácido palmítico (entre 3 e 5\%), ácido palmitoléico (entre 0,1 e 5\%), ácido esteárico (entre 1 e 2\%), outros ácidos graxos como láurico, mirístico, araquidônico, gadoléico e behênico (entre 0 e 1\%); ácidos ativos: ácido transretinoico ou tretinoína natural (entre 0,01 e 0,1\%) (Valladares et al, 1993; Fromm et al, 2012). Além destes, uma significativa porcentagem de fosfolipídios pode ser encontrada, numa quantidade de 20 - 30mg/L de extrato de óleo (Salminen et al, 2005, Kazankaya et al, 2005).

Os ácidos graxos essenciais estão ligados à manutenção da integridade da pele e da estrutura das membranas celulares e à síntese de compostos biologicamente ativos (p. ex., prostaglandinas e leucotrienos). São importantes em muitos processos fisiológicos e bioquímicos do corpo humano relacionados à regeneração dos tecidos e ao crescimento celular (Thielemann, Orrego e Sandoval, 1993). Têm ainda uma função estrutural, formando parte dos fosfolipídios das membranas celulares dos tecidos do organismo, sendo os precursores de prostaglandinas e leucotrienos a partir da síntese do ácido araquidônico (Funck et al, 2006; Pareja, 1996). Já os fosfolipídios intervêm, entre outros, no processo ativo de 
fosforilação, na mitose e organização celular e nos intercâmbios iônicos (Pareja, 1996; Godoy \& Prado, 2005). Entre outros benefícios à saúde atribuídos aos ácidos graxos, destacam-se: anticarcinogênese, antiaterosclerose, inibição de radicais livres, alteração na composição e no metabolismo do tecido adiposo, imunomodulação, atividade antibacteriana e antidiabética (Funck et al, 2006).

Existem diversos tipos de ácidos graxos, mas relacionado a tratamento de feridas, o ácido linoléico e o ácido linolênico são os mais importantes, pois não podem ser sintetizados pelos mamíferos, por não possuírem a enzima delta 9-dessaturase, sendo assim chamados de ácidos graxos essenciais (AGE) (Pereira, 2008).

O ácido linoleico exerce um importante papel quimiotáxico para macrófagos, sendo fundamental na expressão de componentes do sistema fibrinolítico para a regulação da produção de colagenases. Além disso, favorece o desbridamento autolítico no leito da ferida por contribuir com a produção de metaloproteínas na indução da granulação (Ferreira et al, 2012).

Já o ácido linolênico é o lipídio encontrado em maior quantidade na camada epidérmica, atuando no transporte de gorduras e favorecendo a manutenção da integridade da barreira de permeabilidade epidérmica e acelerando processos cicatriciais. Auxilia na manutenção do meio úmido da pele como uma barreira natural de impermeabilidade, o que favorece a quimiotaxia e angiogênese e aceleração do processo de granulação (Ferreira et al, 2012).

Ferreira e colaboradores (2012), em revisão de literatura, listaram nove apresentações comerciais como ácidos graxos essenciais. Entretanto, a maioria das apresentações comerciais utilizadas no tratamento de feridas disponibilizadas no Brasil, genericamente conhecidas por AGE, contém em sua formulação apenas um ou nenhum dos dois ácidos: linoléico ou linolênico, em combinação com outros produtos (Ferreira et al, 2012).

Embora o óleo de Rosa Mosqueta (Rosa aff rubiginosa) tenha sido bastante difundido na indústria cosmética como poderoso agente cicatricial, poucos trabalhos de metodologia científica foram produzidos para confirmar especificamente sua eficácia no tratamento de feridas, cujos resultados tem sido empiricamente comprovados. Entre as indicações dermatológicas do óleo, está o combate ao envelhecimento precoce (Thielemann, Orrego e Sandoval, 1993), clareamento de sardas e estrias, controle de alterações da pele causadas pela radioterapia, prevenção e tratamento de assaduras, redução de marcas e cicatrizes hipercrômicas (Fuji, Ikeda e Saito, 2011), hipertróficas e retráteis causadas por queimaduras, 
feridas, acnes, quelóides, sendo também empregado na terapêutica de úlceras por pressão e em feridas pós-operatórias (plantamed, 2006; Molezzi \& Albedaño, 2002).

Em razão da combinação singular de AGE, Chrubasik et al (2008) e Patel (2013), indicam a necessidade de estudos consistentes para avaliar o potencial do uso tópico da Rosa Mosqueta em lesões e doenças de pele. Esses dados mostram a necessidade de buscar e reunir estudos sobre o uso da Rosa Mosqueta no tratamento de feridas, de forma a avaliar as evidências disponíveis na literatura científica. 


\section{JUSTIFICATIVA}

O interesse pelas propriedades cicatrizantes do óleo de Rosa Mosqueta é justificado pelo impacto que a ocorrência crônica de lesões na pele gera em seus portadores. As feridas crônicas são caracterizadas por atraso na cicatrização apesar do emprego de tratamento. Sua prevalência gira em torno de $15 \%$ da população, implicando em consequências emocionais, físicas, sociais e econômicas (Brolmann et al, 2012) Por esse motivo, divulgação e desenvolvimento de tecnologias para o tratamento de feridas se fazem necessárias, preferentemente mais baratas e acessíveis, como por exemplo, com uso de produtos naturais (Klein et al, 2009).

Desde os primórdios, o homem tenta interferir no processo de cicatrização a fim de reduzir o tempo de resolução da lesão e proporcionar melhores resultados estéticos (Branco Neto et al, 2006). Alterações nas fases de cicatrização, seja por fatores externos quanto internos, acarretam em prolongamento da reparação tecidual e cicatrização anormal. O desenvolvimento de técnicas e produtos capazes de modular as fases da reparação tecidual sempre foi o alvo de estudos relacionados à cicatrização.

A decisão sobre o que usar no tratamento de uma ferida, aguda ou crônica, considera diversos fatores como a fisiopatologia da lesão, o conforto do paciente e sua facilidade de utilização, as características da secreção, a existência de infecção, a profundidade da área afetada, as propriedades do curativo propriamente dito, como também as questões sociais e econômicas do paciente (Smaniotto, 2012).

Atualmente, um extenso arsenal terapêutico para cicatrização de feridas está disponível no mercado e podem ser classificados segundo sua forma de ação (Fan et al, 2011): a) curativos passivos: promovem a proteção e garantem o meio úmido no leito da lesão; b) curativos com princípios ativos: atuam localmente promovendo desbridamento químico, e favorecem a proliferação celular; c) Curativos inteligentes: interagem diretamente com o leito da ferida, alterando o microambiente e induzem estímulos a sinalizadores endógenos; d) curativos biológicos: possuem compostos biológicos heterógenos ou alógenos que mimetizam a ação bioquímica de células teciduais (Smaniotto et al, 2010). A maioria desses produtos atua principalmente na fase inflamatória, modulando a resposta imune e otimizando a limpeza da lesão, ou na fase proliferativa, favorecendo a proliferação e migração celular e a deposição e organização do colágeno.

O uso de curativos proporciona a proteção física da lesão, a retenção de calor, a manutenção da umidade, a regeneração celular e a otimização da ação das enzimas e de 
fatores de crescimento responsáveis pela proliferação e diferenciação celular no leito da ferida. O curativo também previne contaminação e pode promover o desbridamento autolítico. Além disso, possibilita o preenchimento de espaço morto e controle da secreção por absorção, evaporação ou oclusão (Irion, 2012).

Uma das preocupações no tratamento de feridas está em reduzir o número de trocas a fim de interferir o mínimo possível no processo fisiológico e garantir a concentração de fatores de crescimento no leito da lesão. Além disso, o número de trocas influencia nos gastos com materiais, exige mão-de-obra especializada e eleva os riscos de contaminação.

O óleo de Rosa Mosqueta (Rosa aff rubiginosa) tem sido estudado como agente cicatrizante tópico com positivos resultados in vivo (Eurides, 2011; Marchini, 1994), especialmente por suas propriedades anti-inflamatórias (Latanzzio, 2011). Entretanto, o uso do óleo puro ou como solução oleosa é extremamente desconfortável ao paciente, pois apresenta odor e textura desagradável, além de exigir trocas diárias que tornam o tratamento mais oneroso. O desenvolvimento de uma formulação semissólida que permita a manutenção do produto em contato direto com o leito da ferida poderia suplantar essas desvantagens.

Em adição, para garantir a eficácia no tratamento, o produto semissólido deve apresentar características sensoriais adequadas, boa espalhabilidade e estabilidade no leito da ferida, promover a troca de gases e líquidos entre ambientes interno e externo, além de possibilitar a facilidade de remoção durante a higienização minimizando traumas mecânicos no tecido neoformado. Entre as formas farmacêuticas semissólidas disponíveis, as emulsões óleo-em-água, também chamados de cremes O/A, atendem aos critérios mencionados, especialmente quanto ao mascaramento do odor e maior facilidade de remoção da pele por lavagem quando em comparação aos cremes A /O (Thompson, 2009).

Ensaios pré-clínicos com a Rosa Mosqueta, tanto no uso tópico quanto oral, tem demonstrado sua segurança e indicam eficácia enquanto agente anti-inflamatório e cicatrizante. Embora estudos clínicos relacionados à ação cicatrizante sejam encontrados na literatura, a amostra de indivíduos tratados é reduzida e a metodologia pouco clara, o que reduz a validade externa dos estudos, não sendo possível uma recomendação segura. No entanto, o óleo de Rosa Mosqueta tem sido utilizado empiricamente em lesões de pele sendo facilmente encontrado em farmácias de manipulação no Brasil. Neste trabalho, buscamos evidências na literatura científica que forneçam subsídios para o uso do óleo de Rosa Mosqueta no processo de cicatrização. A partir daí, propomos o desenvolvimento de uma emulsão utilizando óleo de Rosa Mosqueta que foi submetida, juntamente com o óleo puro, à 
avaliação de eficácia no processo de cicatrização por meio de estudo morfológico e morfométrico da cicatrização de lesões confeccionadas em ratos Wistar adultos. 


\section{Objetivo Geral}

Avaliar a eficácia do óleo de Rosa Mosqueta na reparação tecidual e sua influência nas fases de cicatrização por meio de estudo morfométrico e morfológico de lesões confeccionadas em ratos. Como inovação, este trabalho pretende comparar a eficácia do óleo puro com uma emulsão óleo em água elaborada com 30\% desse óleo. Por sua vez, a eficiência de ambos os produtos serão avaliados comparando-se os resultados com outro produto já amplamente utilizado na prática clínica para tratamento de feridas.

\section{Objetivos específicos}

- Identificar, na literatura científica, níveis de evidência sobre o uso do óleo de Rosa Mosqueta na cicatrização de feridas;

- Desenvolver uma formulação óleo/água elegante e estável, contendo óleo de Rosa Mosqueta e avaliar a estabilidade dessa formulação a partir de características físico-químicas, químicas e microbiológicas;

- Verificar e comparar a eficácia do óleo de Rosa Mosqueta e da emulsão contendo 30\% desse óleo no processo de cicatrização de ratos Wistar adultos por meio de avaliação morfológica e morfométrica. 


\subsection{A ROSA MOSQUETA COMO POTENCIAL AgENTE CICATRIZANTE: REVISÃO INTEGRATIVA}

\section{Método}

Foi realizada revisão integrativa sobre o uso do óleo de Rosa Mosqueta na cicatrização de feridas empregando-se as seguintes etapas: elaboração da hipótese e definição dos objetivos da pesquisa; busca na literatura para definição dos descritores bem como delimitação dos critérios de inclusão e exclusão; coleta dos dados; análise crítica dos estudos incluídos; discussão dos resultados e finalmente a apresentação da revisão (Souza et al, 2010).

Como pergunta norteadora desta revisão foi levantada a seguinte questão: que evidências existem na literatura científica que comprovem a eficácia do óleo de Rosa Mosqueta na cicatrização de feridas? Foram incluídos artigos publicados nas línguas inglesa, espanhola e portuguesa que apresentassem como tema de estudo unicamente a aplicação tópica do óleo de Rosa Mosqueta no processo de cicatrização cutânea.

A busca foi realizada entre julho e setembro de 2015 nas bases de dados eletrônicas Literatura Latino-Americana de Ciências da Saúde (Lilacs), Biblioteca Virtual em Saúde (BVS), Medical Literature Analysis and Retrieval System on Line (Medline), Biblioteca Cochrane, Scientific Eletronic Library Online (Scielo), National Library of Medicine (PubMed) e Proquest, por meio dos descritores "Rosa Mosqueta", "wound", "Rosa aff rubiginosa", "healing" ou "Rosa canina". Não foi estabelecido recorte de tempo para esta revisão. Publicações repetidas em diferentes bases foram contabilizadas apenas uma vez, e aquelas não indexadas nas bases de dados digitais, porém consideradas importantes para essa pesquisa foram resgatadas por meio do Programa de Comutação Bibliográfica - COMUT.

As publicações listadas nas bases de dados com os descritores acima foram préselecionadas a partir dos títulos e submetidos à avaliação de seus resumos quanto aos objetivos e resultados. A leitura completa da publicação foi realizada apenas para os trabalhos que apresentaram informações incoerentes.

Para coleta de dados dos artigos incluídos nessa revisão foi utilizado instrumento validado por Ursi et al (2006) cujos itens contemplam a identificação do artigo original, características metodológicas do estudo, avaliação do rigor metodológico, das intervenções 
mensuradas e dos resultados encontrados (Ursi et al, 2006). Os níveis de evidência dos trabalhos foram avaliados segundo a classificação do Oxford Centre for Evidence-Based Medicine (OCEBM, 2011) e a qualidade metodológica dos ensaios clínicos foi avaliada utilizando-se a escala de Jadad (Jadad, 1996). Os dados coletados foram então analisados e a síntese dos trabalhos foi feita por meio de quadro sinóptico.

\section{Resultados e Discussão}

A busca eletrônica, ilustrada na Tabela 1, permitiu o agrupamento de 43 publicações.

Tabela 1 Relação de descritores e número total de trabalhos resgatados por base de dados pesquisada. Brasília, 2015

\begin{tabular}{llcc}
\hline $\begin{array}{c}\text { Base de } \\
\text { Dados }\end{array}$ & \multicolumn{1}{c}{ Descritores } & $\begin{array}{c}\text { Número de } \\
\text { publicações } \\
\text { encontradas }\end{array}$ & $\begin{array}{c}\text { Número de } \\
\text { publicações } \\
\text { selecionadas }\end{array}$ \\
\hline Lilacs & "Rosa Mosqueta" & 07 & 03 \\
\hline $\boldsymbol{B V S}$ & "Rosa aff rubiginosa" OR "Rosa & 11 & 08 \\
& Mosqueta" AND "Wound healing" & &
\end{tabular}

\begin{tabular}{llll}
\hline Medline & "Rosa aff rubiginosa" & 01 & 01 \\
\hline Pubmed "Rosa aff rubiginosa" or "Rosa & 02 & 02 \\
& Mosqueta" and "wound healing"
\end{tabular}

\begin{tabular}{llcc}
\hline Scielo "Rosa Mosqueta" & 06 & 01 \\
\hline DOAJ "Rosa Mosqueta" or "Rosa aff & 06 & 02 \\
rubiginosa"
\end{tabular}

\begin{tabular}{llll}
\hline Cochrane & Rosa Mosqueta & 01 & 0 \\
\hline Proquest & $\begin{array}{l}\text { "Rosa aff rubiginosa" OR "Rosa } \\
\text { canina" AND "wound" }\end{array}$ & 20 & 0
\end{tabular}

\begin{tabular}{lcc}
\hline Repetições (-) & 11 & 11 \\
\hline Total & 43 & 6 \\
\hline
\end{tabular}

A pré-seleção excluiu 37 trabalhos disponibilizados por meio eletrônico, restando apenas 6 que contemplaram os critérios de inclusão. Uma publicação foi posteriormente 
adicionada à amostra, solicitada por meio do COMUT, por não estar disponível nas bases de dados on-line. A figura 6 ilustra o processo de seleção e inclusão dos trabalhos selecionados.

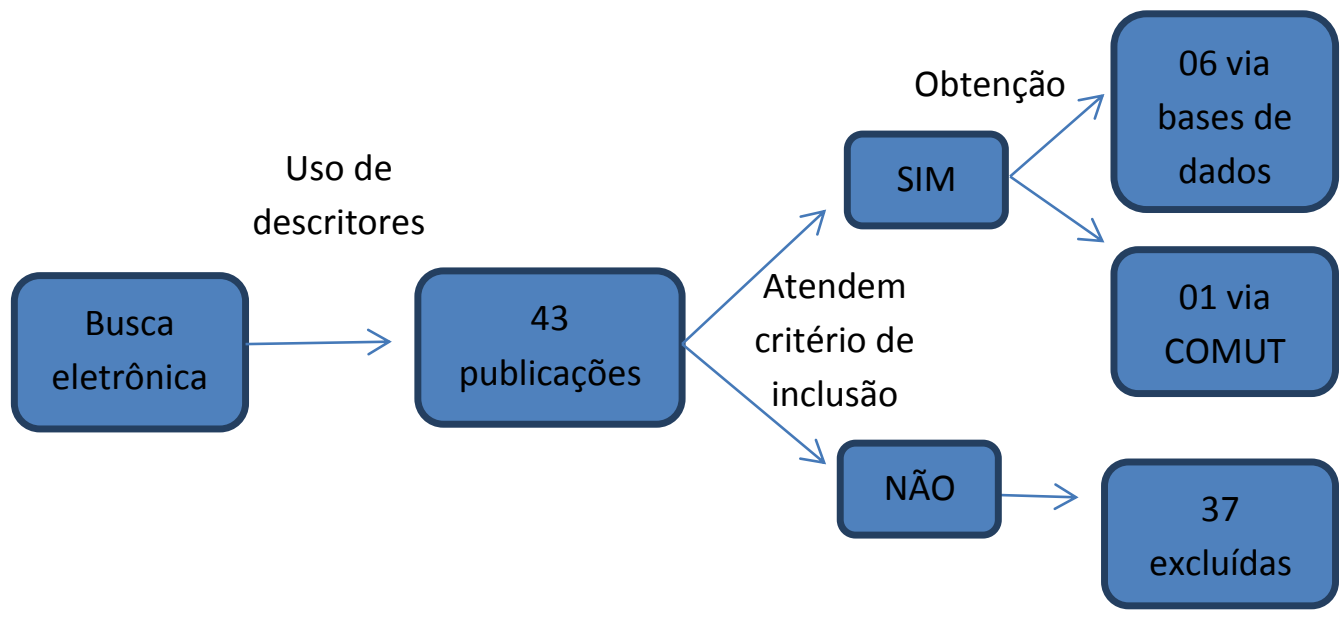

Figura 6 Esquematização para obtenção das publicações presentes na revisão integrativa. Brasília, 2015.

A Biblioteca Virtual em Saúde foi a base de dados mais sensível aos descritores utilizados, apresentando o maior número de publicações selecionadas (Tabela 1). A amostra foi constituída por cinco artigos $(71,4 \%)$, uma dissertação $(14,3 \%)$ e uma carta enviada à redação $(14,3 \%)$. A origem das publicações foi predominantemente brasileira $(\mathrm{N}=5 ; 71,4 \%)$, seguida pela espanhola $(\mathrm{N}=2 ; 28,6 \%)$. Quando avaliado o idioma de publicação, entretanto, essa diferença torna-se menor, já que quatro trabalhos foram publicados em Português $(57,15 \%)$ e três publicados em Espanhol $(42,85 \%)$. Todos os trabalhos analisados estavam ligados à área de pesquisa de Universidades brasileiras ou espanholas, apenas dois artigos foram desenvolvidos em unidades hospitalares e um artigo apresentou a participação de mais de uma instituição.

Em relação à área de formação dos pesquisadores, quatro dos artigos analisados foram publicados por médicos $(57,1 \%)$, um não especificava a área de formação $(14,3 \%)$ e outros dois foram publicados por enfermeiros $(14,3 \%)$ e médicos veterinários (14,3\%) cada. Em relação ao tipo de periódico, dois trabalhos foram publicados em revistas médicas $(28,6 \%)$, um trabalho em revista de enfermagem geral $(14,3 \%)$ e outro em revista de medicina veterinária $(14,3 \%)$. Um dos trabalhos não foi publicado em revista e outros dois foram publicados em revistas de outras áreas da saúde $(28,6 \%)$.

Quanto ao tipo de delineamento dos estudos avaliados evidenciou-se uma revisão de literatura, três estudos experimentais não clínicos, um estudo clínico de delineamento não- 
experimental, um estudo com delineamento quase-experimental e outro com delineamento experimental, porém de baixa qualidade metodológica. A qualidade metodológica dos estudos clínicos foi avaliada como baixa segundo a escala de Jadad. A tabela 2 apresenta a síntese dos trabalhos incluídos nesta revisão e a tabela 3, mostra a avaliação dos estudos segundo nível de evidência e qualidade metodológica para estudos clínicos.

Tabela 2 Trabalhos consultados na revisão integrativa sobre óleo de Rosa mosqueta. Brasília, 2015.

$\begin{array}{lll}\text { AUTORES } & \text { ANO } & \text { TIPO DE } \\ & \text { ESTUDO } & \text { OBSERVAÇÕES }\end{array}$

\begin{tabular}{llll}
\hline $\begin{array}{l}\text { MARCHINI F.B } \\
\text { et al. }\end{array}$ & Estudo não & $\begin{array}{l}\text { O óleo possibilitou cicatrização eficiente das } \\
\text { clínico }\end{array}$ & $\begin{array}{l}\text { feridas em ratos wistar, com tecido de } \\
\text { granulação mais organizado e maior } \\
\text { deposição de colágeno que o grupo controle. }\end{array}$ \\
GIMENEZ J.C.M 1990 & $\begin{array}{l}\text { Quase } \\
\text { experimental } \\
\text { placebo } \\
\text { controlado }\end{array}$ & $\begin{array}{l}\text { Úlceras varicosas ou feridas pós-operatórias } \\
\text { de indivíduos tratados com óleo } \\
\text { apresentaram menor tempo de cicatrização, } \\
\text { comamostra } \\
\text { pareada. }\end{array}$ & efeitos colaterais. \\
& &
\end{tabular}

\begin{tabular}{|c|c|c|c|}
\hline $\begin{array}{l}\text { MARCHINI, } \\
\text { F.B. }\end{array}$ & 1994 & $\begin{array}{l}\text { Estudo não } \\
\text { clínico }\end{array}$ & $\begin{array}{l}\text { Ratos Wistar machos tratados com óleo } \\
\text { apresentaram tecido de granulação com } \\
\text { desenvolvimento e organização mais } \\
\text { acelerados, remodelação de colágeno mais } \\
\text { acentuada e maior número de fibroblastos em } \\
\text { comparação ao grupo controle. }\end{array}$ \\
\hline $\begin{array}{l}\text { CAÑELLAS, M. } \\
\text { et al. }\end{array}$ & 2008 & $\begin{array}{l}\text { Estudo } \\
\text { experimental }\end{array}$ & $\begin{array}{l}\text { O estudo indica que o uso do óleo refinado } \\
\text { em humanos com ferimento pós-cirúrgico } \\
\text { podológico deve ser realizado após } 48 \mathrm{~h} \text { para } \\
\text { evitar a ocorrência de maceração da cicatriz. } \\
\text { Este tipo de óleo proporciona reconstituição } \\
\text { tecidual com cicatriz mínima. Enquanto que } \\
\text { o óleo bruto não apresenta estabilidade. }\end{array}$ \\
\hline
\end{tabular}

\begin{tabular}{lll}
$\begin{array}{l}\text { SANTOS, JS, et 2009 } \\
\text { al. }\end{array}$ & $\begin{array}{l}\text { Estudo de } \\
\text { Revisão }\end{array}$ & $\begin{array}{l}\text { Os trabalhos presentes na revisão enfatizam a } \\
\text { associação de ácidos graxos essenciais } \\
\text { (linoléico, linolênico e oléico) como } \\
\text { possíveis responsáveis do efeito terapêutico } \\
\text { do óleo de rosa mosqueta em feridas abertas. }\end{array}$ \\
$\begin{array}{l}\text { MADJAROF, C. 2011 } \\
\& \text { LINARELLI, }\end{array}$ & Estudo não- & $\begin{array}{l}\text { Indivíduos com cicatriz hipertrófica } \\
\text { apresentaram melhora da textura, elasticidade }\end{array}$ \\
\hline
\end{tabular}




\begin{tabular}{lll}
\hline M.C.B. & experimental & $\begin{array}{l}\text { e aparência geral da cicatriz após 28 dias de } \\
\text { uso. }\end{array}$ \\
EURIDES, D et 2011 & $\begin{array}{l}\text { Estudo não } \\
\text { clínico } \\
\text { controlado }\end{array}$ & $\begin{array}{l}\text { O grupo de ratos tratados com óleo } \\
\text { apresentou redução do edema, menor área de } \\
\text { lesão, maior deposição de colágeno e } \\
\text { completa epitelização no } 13^{\circ} \text { dia pós } \\
\text { operatório em relação ao grupo controle. }\end{array}$ \\
\end{tabular}

Tabela 3 Avaliação dos trabalhos consultados por nível de evidência e qualidade metodológica para estudos clínicos. Brasília, 2015.

\begin{tabular}{lcc}
\hline \multicolumn{1}{c}{ Artigos } & Nível de Evidência & Índice de Jadad \\
\hline MARCHINI FB et al.1988 & 5 & $N A$ \\
GIMENEZ JCM et al. 1990 & 4 & 0 \\
MARCHINI FB. 1994 & 5 & $N A$ \\
CANEELLAS M et al. 2008 & 2 & 2 \\
SANTOS JS et al. 2009 & 5 & $N A$ \\
MADJAROF C \& & 3 & 0 \\
LINARELLI MCB. 2011 & & $N A$ \\
EURIDES D et al. 2011 & 5 & \\
\hline
\end{tabular}

A eficácia do óleo de Rosa Mosqueta no processo de cicatrização vem sendo estudada nas últimas três décadas, com destaque para a produção brasileira. Apesar disso, poucos estudos sobre o tema foram publicados (Marchini, 1994; Winther, 2013; Santos, 2009; Marchini et al, 1988; Gimenez, 1990; Canellas, 2008; Eurides, 2011; Madjarof, 2011).

O interesse pelo óleo de Rosa mosqueta surgiu em 1988, com o primeiro estudo experimental não clínico realizado por Marchini, que a partir de então, seguiu nesta mesma linha para avaliar a eficácia deste insumo no processo de cicatrização de feridas em ratos Wistar (Marchini, 1994; Marchini et al, 1988)

A avaliação histológica das lesões tratadas com o óleo mostrou um tecido cicatricial com maior deposição de colágeno, menor número de macrófagos e maior quantidade de fibroblastos aos 7, 14 e 21 dias de regeneração. Além disso, observou também que as lesões apresentavam tecido de cicatrização mais avançado com tecido de granulação mais organizado que o grupo controle (Marchini, 1994). 
Eurides et al (2011) obteve resultados semelhantes ao observar que as lesões tratadas com óleo de Rosa Mosqueta apresentaram redução do edema, menor área de lesão a partir do sétimo dia pós-operatório (DPO), maior deposição de colágeno e completa epitelização no $13^{\circ}$ dia quando comparado ao grupo controle tratado com solução de soro fisiológico a $0,9 \%$ (Eurides, 2011).

Apesar de não oferecerem níveis de evidência suficientes para uma recomendação clínica, os estudos em animais permitem investigar eficácia e segurança de um produto novo antes de ser testado em humanos. Nos estudos dessa natureza levantados nesta revisão, o achado mais importante foi a redução de infiltrado inflamatório e boa organização de colágeno das lesões tratadas com óleo de Rosa Mosqueta quando comparado ao grupo controle. Apesar dos resultados satisfatórios desses estudos, a comparação do grupo experimento se deu apenas com o tratamento placebo com soro fisiológico, sendo interessante a inclusão de um controle positivo para avaliação da eficácia do óleo de Rosa Mosqueta na cicatrização de feridas.

A capacidade anti-inflamatória do óleo de Rosa Mosqueta pode ser de interesse clínico no tratamento de feridas, especialmente naquelas de difícil tratamento. A cicatrização envolve uma sequência de eventos complexos e sobrepostos que devem se equilibrar para um adequado reparo tecidual. Após o dano celular, o primeiro evento a ser desencadeado é a hemostasia por meio da cascata de coagulação. Nesse processo, o fibrinogênio é convertido em fibrina, que, ao ser polimerizada, forma uma capa que recobre a lesão e que servirá de matriz provisória para a invasão de vários tipos celulares (Irion, 2012). Cerca de $24 \mathrm{~h}-48 \mathrm{~h}$ depois, células inflamatórias começam a infiltrar na ferida, degradando a camada de fibrina que será substituída por colágeno (Irion, 2012). Esse processo inflamatório permite a limpeza do tecido lesionado para substituição de tecido novo. Entretanto, se a inflamação local se mantém além do esperado, o período de fechamento da lesão é prolongado, favorecendo a ocorrência de infecções, exsudatos, necroses e a formação de um tecido de má qualidade.

Em revisão de literatura, Santos et al (2009), reuniram informações sobre a composição bioquímica do óleo de forma a levantar evidências sobre seu uso na cicatrização de feridas. As informações reunidas indicam que a Rosa Mosqueta tem propriedades cicatrizantes pela combinação de ácido oléico, linoléico e linolênico (Ferreira, 2012). Tais compostos, conhecidos como ácidos graxos são importantes componentes estruturais das membranas biológicas, além de atuarem como precursores de mensageiros intracelulares, pois quando oxidados, geram adenosina trifosfato (ATP) (Ferreira, 2012). Ressalta-se também a 
presença de fenóis e carotenóides encontrados no óleo de Rosa Mosqueta, cujas propriedades antioxidativas podem favorecer a regeneração tecidual (Cunja, 2015).

Foram encontrados três estudos clínicos com o óleo de Rosa Mosqueta no tratamento de feridas ou relacionado ao modelamento cicatricial. O primeiro deles, relatado por Gimenez et al (1990), foi um estudo experimental que avaliou o efeito do óleo a $26 \%$ na cicatrização de feridas de etiologia variada. Os pesquisadores incluíram 10 pacientes portadores de úlceras venosas ou pós-cirúrgicas de difícil cicatrização e avaliaram o tempo de cura e a recidiva de lesões comparados com grupo controle de amostra pareada. Foram avaliados pacientes com úlceras varicozas, úlceras postraumáticas, eczemas de contato e deiscências pós-cirúrgicas. Os autores verificaram que o grupo tratado com o óleo apresentou processo de cicatrização mais avançado, com tecido de granulação mais organizado e maior deposição de colágeno que o grupo controle. Observou-se uma diferença de até 29 dias no tempo de cicatrização entre o grupo tratado e o grupo controle (23,25 dias para o grupo terapêutico contra 52,2 dias para o grupo controle).

Apesar do bom resultado descrito, alguns vieses devem ser destacados: a amostra de apenas 10 pacientes restringe os achados do estudo. Além disso, não fica claro a forma de aleatorização da amostra e o tipo de produto utilizado para o grupo controle. Há que se destacar também que a inclusão de diferentes tipos de feridas dificulta a comparação dos resultados. O estudo não confere clareza metodológica, os dados são pouco objetivos e o tratamento estatístico se restringiu à descrição das proporções, não permitindo confirmar se as diferenças encontradas são estatisticamente significativas.

Um estudo clínico experimental, realizado por Cañellas et al (2008), testou o óleo de Rosa Mosqueta bruto e refinado em ferida operatória de cirurgias podológicas em 50 pacientes, comparando-as com grupo controle por 12 dias. Eles não encontraram diferenças no tempo de cicatrização, porém concluíram que o óleo refinado melhora o processo de cicatrização, produzindo uma cicatriz mínima. O óleo bruto não deve ser utilizado por não apresentar estabilidade com o tempo. Destacaram também que o uso do óleo em feridas póscirúrgicas, cicatrizando por primeira intenção, deve ser utilizado $48 \mathrm{~h}$ após o procedimento para evitar o excesso de maceração do tecido. O estudo, entretanto, não esclarece como foi realizada a randomização da amostra nem especifica o tipo de produto utilizado no grupo controle. Quanto ao tratamento dos dados, foi aplicado apenas estatística descritiva, o que não permite afirmar se as diferenças encontradas são significantes.

Estudo proposto por Madjarof e Linarelli (2011), investigou o efeito de um produto comercial (Rinopel®) em 23 pacientes de 18 a 60 anos com cicatriz hipertrófica formada há 
no máximo quatro meses. Foi avaliada textura, elasticidade e aparência geral da cicatriz tanto pelos pacientes quanto pelos pesquisadores utilizando o Standard Guide for Sensory Claim Substantiation. Após 28 dias de uso do produto 87,0\%, 82,6\% e 95,7\% dos voluntários/julgadores referiram melhora da textura, elasticidade e aparência geral da cicatriz, respectivamente. $\mathrm{O}$ estudo, porém, utiliza amostra de conveniência, não possui grupo controle e não padronizou dose e quantidade de aplicações. Ademais, o produto utilizado é uma combinação de óleo de Rosa Mosqueta, óleo de Centella Asiática e de vitamina E, não sendo possível afirmar se os efeitos observados são atribuídos à Rosa Mosqueta. A análise estatística é apenas descritiva e o estudo não fornece protocolo do Comitê de ética.

Com base nos dados levantados, é possível observar que nas últimas três décadas pouco se avançou na avaliação da eficácia da Rosa Mosqueta no processo de cicatrização. Os estudos clínicos levantados nesta pesquisa possuem vieses metodológicos que reduzem o nível de evidência e não são suficientes para uma recomendação. Entretanto, os resultados de estudos não clínicos mostram que o óleo de Rosa Mosqueta pode ter atividade imunomodulatória no leito da ferida e favorecer a deposição de colágeno e organização tecidual.

Em feridas pós-operatórias, um estudo sugere que o óleo deve ser utilizado após $48 \mathrm{~h}$ do procedimento cirúrgico a fim de evitar maceração do tecido. Ressalta-se também que o óleo refinado apresentou melhores resultados que o óleo bruto. Outro estudo mostra evidências de que o óleo pode ter efeitos terapêuticos mesmo em uma concentração mais baixa, a $26 \%$.

Os estudos encontrados nesta revisão não apresentaram nível de evidência suficiente para uma recomendação segura do óleo de Rosa Mosqueta no tratamento de feridas. Apesar disso, a composição bioquímica do óleo fornece subsídios para inferir que essa planta pode trazer benefícios no tratamento de lesões, especialmente as de difícil cicatrização, pela sua atividade imunomodulatória.

Em adição, a necessidade de elaboração de um produto farmacêutico à base do óleo de Rosa Mosqueta se faz de particular interesse para a prática clínica, pois permitirá maior estabilidade deste insumo, que permanecerá maior tempo em contato com o leito da ferida e provavelmente reduzirá o incômodo do paciente e custos do tratamento. 
5.2 DESENVOLVIMENTO E ESTUDO DE ESTABILIDADE ACELERADA DE EMULSÃO À BASE DE ÓLEO DE ROSA MOSQUETA

\section{Materiais e Métodos}

\section{Composição das formulações}

As composições das formulações de soluções e emulsões à base de óleo de Rosa Mosqueta objeto de estudo estão indicadas no quadro 2.

Quadro 2 Composição (\%) das formulações desenvolvidas à base de óleo de Rosa Mosqueta. Brasília, 2015.

\begin{tabular}{|c|c|c|c|c|c|c|c|}
\hline \multirow{2}{*}{ Insumos } & \multirow{2}{*}{$\begin{array}{l}\text { Função dos } \\
\text { insumos }\end{array}$} & \multicolumn{2}{|c|}{$\begin{array}{c}\text { Soluções } \\
\text { oleosas } \\
(\% \text { p/p })\end{array}$} & \multicolumn{4}{|c|}{$\begin{array}{l}\text { Emulsões } \\
(\% \text { p/p) }\end{array}$} \\
\hline & & $\begin{array}{c}\text { S100 } \\
\text { RM1 } \\
\text { 00 } \\
\end{array}$ & $\begin{array}{c}\text { S30 } \\
\text { RM } \\
\mathbf{3 0} \\
\end{array}$ & $\begin{array}{l}\mathbf{E 5 0} \\
\mathbf{C 5 0}\end{array}$ & $\begin{array}{l}\text { E30 } \\
\text { C30 }\end{array}$ & $\begin{array}{l}\mathrm{E} 25 \\
\mathrm{C} 25\end{array}$ & $\begin{array}{l}\text { E15 } \\
\text { C15 }\end{array}$ \\
\hline $\begin{array}{c}\text { óleo de Rosa } \\
\text { Mosqueta } \\
\text { (Pharma Nostra, lote } \\
\left.n^{\circ} 37 / 01\right)\end{array}$ & $\begin{array}{l}\text { Princípio ativo, } \\
\text { agente oclusivo e } \\
\text { de emoliência, } \\
\text { veículo da fase } \\
\text { oleosa }\end{array}$ & 100 & 30 & 50 & 30 & 25 & 15 \\
\hline $\begin{array}{c}\text { Tween } \mathbf{2 0} \\
\text { (DINÂMICA®, lote } \\
58914)\end{array}$ & $\begin{array}{c}\text { Agente } \\
\text { emulsificante }\end{array}$ & - & - & 2,5 & 2,5 & 2,5 & 2,5 \\
\hline $\begin{array}{c}\text { Álcool cetoestearílico } \\
\text { etoxilado } \\
\text { (Casa da Química, } \\
\text { lote } 8083 \text { ) }\end{array}$ & $\begin{array}{c}\text { Agente } \\
\text { emulsificante e } \\
\text { agente de } \\
\text { viscosidade }\end{array}$ & - & - & 2,5 & 2,5 & 2,5 & 2,5 \\
\hline Óleo mineral & $\begin{array}{l}\text { Veículo da fase } \\
\text { oleosa, agente } \\
\text { oclusivo e de } \\
\text { emoliência }\end{array}$ & - & 70 & - & - & - & - \\
\hline $\begin{array}{c}\text { Propilparabeno } \\
\text { (Ueno Fine Chemicals } \\
\text { - lote } 3185 \text { ) }\end{array}$ & $\begin{array}{l}\text { Conservante } \\
\text { microbiolóoico }\end{array}$ & - & - & 0,02 & 0,02 & 0,02 & 0,02 \\
\hline $\begin{array}{c}\text { Metilparabeno } \\
\text { (Opção Fenix - lote } \\
9900411)\end{array}$ & & - & - & 0,18 & 0,18 & 0,18 & 0,18 \\
\hline $\begin{array}{c}\text { Carbômero } 940 \\
\text { (Sumitomo Chemical) }\end{array}$ & $\begin{array}{l}\text { Agente de } \\
\text { viscosidade }\end{array}$ & - & - & 0,25 & 0,25 & 0,25 & 0,25 \\
\hline $\begin{array}{c}\text { Glicerina } \\
\text { (Synth, lote 128492) }\end{array}$ & $\begin{array}{c}\text { Emoliente e } \\
\text { umectante ou } \\
\text { agente molhante }\end{array}$ & - & - & 9 & 9 & 9 & 9 \\
\hline Água destilada & $\begin{array}{c}\text { Veículo da fase } \\
\text { aquosa }\end{array}$ & - & - & 35,5 & 55,5 & 60,55 & 70,55 \\
\hline
\end{tabular}

Nota: E indica emulsões e S soluções oleosas. 


\section{Preparo das soluções oleosas}

A solução oleosa S30 foi preparada a partir da diluição do óleo vegetal com óleo mineral a uma fração de 30\%. A solução oleosa S100 apresentou 100\% de óleo de Rosa Mosqueta em sua constituição, sendo submetido apenas à manipulação de envase.

\section{Preparo das emulsões}

As emulsões com distintas proporções de óleo Rosa Mosqueta (50, 30, 25 e 15\% p/p) foram elaboradas pelo método de inversão de fases.

Os constituintes sólidos da fase aquosa (carbômero 940, metilparabeno e propilparabeno) foram totalmente solubilizados na mistura de glicerina e água destilada. Após dissolução, o pH foi ajustado com trietanolamina até aproximadamente 5,5 para formação do gel de carbômero.

A fase oleosa da emulsão foi elaborada a partir da mistura do óleo de Rosa Mosqueta com os agentes emulsionantes, Tween-20 e álcool cetoestearílico etoxilado.

Ambas as fases foram submetidas ao aquecimento até $70^{\circ} \mathrm{C}$. Em seguida, a fase oleosa foi vertida sobre a fase aquosa e misturada constantemente com auxílio do agitador mecânico, durante 30 minutos. $\mathrm{O}$ pH foi ajustado a 5,5 adicionando-se trietanolamina e/ou solução de ácido cítrico à $10 \%$.

\section{Seleção da emulsão para estudo de estabilidade acelerada}

\section{Análise organoléptica das formulações}

A seleção da emulsão submetida ao estudo de estabilidade acelerada foi baseada na análise sensorial da cor, odor e consistência das formulações após $24 \mathrm{~h}$ do preparo (Gil et al, 2010).

As emulsões foram classificadas com ou sem odor característico do óleo de Rosa Mosqueta ou de ranço, de coloração branca ou amarela e aspecto emulsionado consistente, emulsionado fluido ou quebra de emulsão.

As soluções oleosas, S100 e S30, também foram submetidas à análise organoléptica e suas características usadas como parâmetros de comparação para a caracterização das emulsões. 


\section{Estudo de estabilidade acelerada}

A emulsão E30 e as soluções oleosas S30 e S100 foram submetidas ao estudo de estabilidade acelerada em câmara climática à $40{ }^{\circ} \mathrm{C}$ e $75 \%$ UR por 90 dias.

Os ensaios físicos, químicos, físico-químicos e microbiológicos a que foram submetidos os produtos ocorreram no $1^{\circ}, 7^{\circ}, 15^{\circ}, 30^{\circ}, 60^{\circ}$ e $90^{\circ}$ dia após manufatura e/ou envase (Vadas, 2004).

\section{Acondicionamento dos produtos}

Lotes de $200 \mathrm{~g}$, em triplicata, de cada produto foram divididos em alíquotas de $30 \mathrm{~g}$. As amostras foram acondicionadas em 6 frascos de vidro transparente com tampa rosqueável e capacidade para $50 \mathrm{~mL}$ e armazenadas à $40^{\circ} \mathrm{C}$ e $75 \%$ UR por 90 dias.

\section{$\underline{\text { Teste de perda de massa }}$}

A massa das amostras acondicionadas nos frascos com tampa foi aferida em balança analítica no $1^{\circ}, 7^{\circ}, 15^{\circ}, 30^{\circ}, 60^{\circ}$ e $90^{\circ}$ dia após envase. A perda de massa (P\%) foi calculada a partir da relação da massa inicial $\left(\mathrm{M}_{\mathrm{o}}\right)$ aferida no $1^{\circ}$ dia de coleta e a diferença da massa inicial e massa obtida nos demais dias de coleta $\left(\mathrm{M}_{\mathrm{d}}\right)$, de acordo com a equação 1 .

Equação 1

$$
\mathrm{P}(\%)=100 \times\left(\mathrm{M}_{\mathrm{o}}-\mathrm{M}_{\mathrm{d}}\right) / \mathrm{M}_{\mathrm{o}}
$$

\section{$\underline{\text { Teste organoléptico }}$}

Análise sensorial de cor, odor e aspecto dos produtos realizada $24 \mathrm{~h}$ após manufatura e/ou envase dos produtos foi usada como parâmetro de comparação, seguindo o protocolo descrito à continuação (Brasil, 2004; Brasil, 2008):

Caracterização da cor e odor: normal (N) ou alterada (A).

Caracterização do aspecto: emulsionado consistente $(\mathbf{C})$; emulsionado fluido (F); separação de fases ou quebra de emulsão (S). 


\section{$\underline{\text { Teste de centrifugação }}$}

A estabilidade frente ao estresse mecânico foi avaliada através do teste de centrifugação. Alíquotas de $2 \mathrm{~g}$ da emulsão E30, em triplicata, foi submetida a $3000 \mathrm{rpm}$ por 30 minutos à temperatura ambiente em microcentrífuga.

O índice de cremeação $(\mathrm{C} \%)$ foi calculado através da relação entre a fase emulsionada $\left(V_{E}\right)$ e o volume total $\left(V_{t}\right)$, de acordo com a equação 2 (Rodrigues, 2013).

Equação 2

$$
\mathrm{C}(\%)=100 \times\left(\mathrm{V}_{\mathrm{E}} / \mathrm{V}_{\mathrm{t}}\right)
$$

\section{$\underline{\text { Teste de } p H}$}

Alíquotas de $1 \mathrm{~g}$ da emulsão E30, em triplicata, foram dispersas em $10 \mathrm{~mL}$ de água destilada e submetidas a leitura em pHmetro digital (Gehaka® ${ }^{\circledR}$ PG 1800) previamente calibrado (Rodrigues, 2013; Velasco et al, 2008).

\section{$\underline{\text { Teste de espalhabilidade }}$}

A determinação da espalhabilidade foi realizada com adaptação da metodologia de Knorst (1991), utilizando um aparato de placas de vidro montado sobre papel milimetrado. Uma placa-molde com $20 \mathrm{~cm}$ de diâmetro, $0,3 \mathrm{~cm}$ de espessura e com orifício central de $1,2 \mathrm{~cm}$ de diâmetro foi colocada sobre uma placa-suporte de vidro $(20 \mathrm{~cm}$ x $20 \mathrm{~cm})$ posicionada sobre o papel milimetrado.

A emulsão foi introduzida no orifício da placa-molde e a superfície nivelada com espátula. Após cuidadosa retirada da placa-molde foram adicionadas, sucessivamente, cinco placas de vidro de massa aproximada e conhecida em intervalos de um minuto.

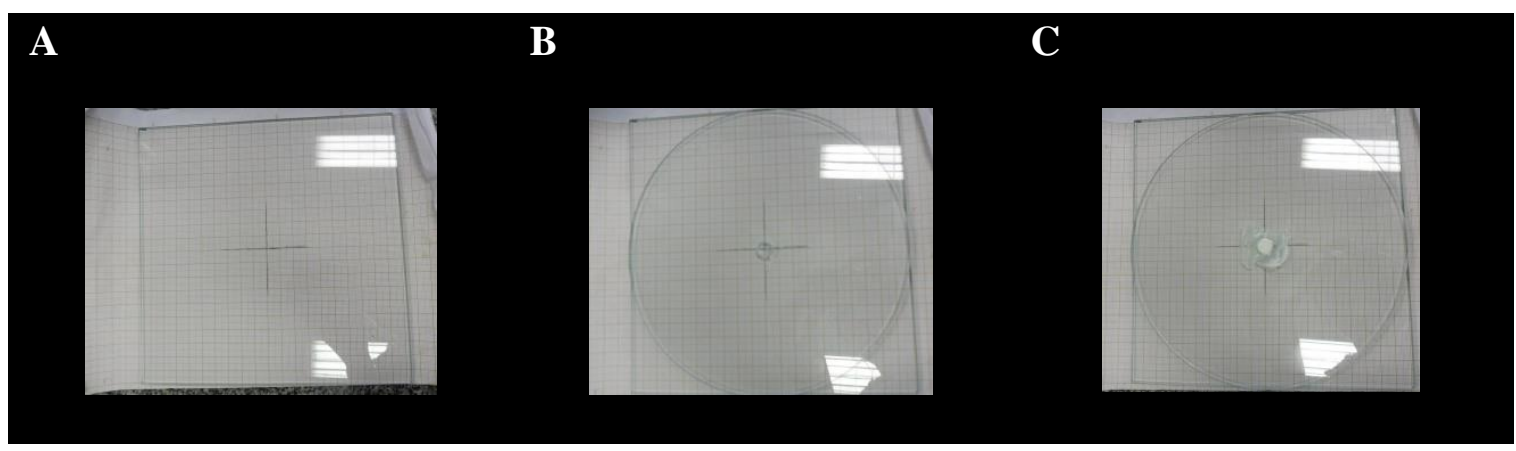




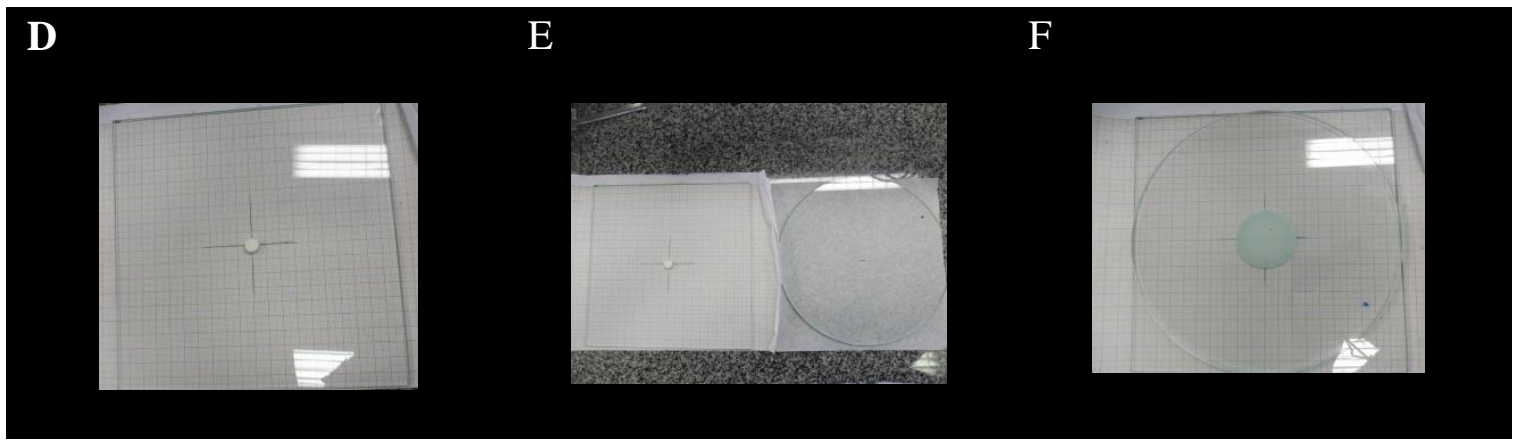

Figura 7 Procedimentos para avaliação do índice de espalhabilidade. A - placa de vidro posicionada sobre papel milimetrado; B - placa molde com orifício central; C - preenchimento do orifício central com a amostra da emulsão; D - visualização do volume de amostra submetido à espalhabilidade após retirada da placa molde; E e F - posicionamento das placas de vidro para avaliação da espalhabilidade, medindo-se os diâmetros horizontal e vertical da área ocupada pelo creme.

Foi calculada a média dos diâmetros (d) abrangidos pela amostra em posições opostas (horizontal e vertical) e a espalhabilidade (Ei) obtida através da equação 3 (Knorst, 1991).

Equação 3

$$
\mathrm{Ei}=\mathrm{d}^{2} \times \pi / 4
$$

Onde d representa a média dos diâmetros horizontal e vertical obtido em cada placa.

\section{$\underline{\text { Teste microbiológico }}$}

Os testes microbiológicos das emulsões e das soluções oleosas foram realizados segundo as orientações da Farmacopeia Brasileira (2010). Foram realizados ensaios descritos para produtos não estéreis visando garantir a qualidade e o controle de fabricação previstos nas boas práticas visando atender os parâmetros dos limites aceitáveis para microrganismos neste tipo de formulação.

Para os ensaios microbiológicos, uma alíquota do produto nos diferentes dias de análise foram coletadas em francos estéreis, com técnica asséptica, em capela de fluxo laminar classe II. As alíquotas foram pesadas e encaminhadas para o laboratório de análise microbiológica.

Preparo das amostras: De cada amostra foi pesado $1 \mathrm{~g}$ da alíquota e diluída em $9 \mathrm{~mL}$ de solução tampão cloreto de sódio-peptona, pH 7,0 , configurando uma diluição na proporção 1:10. Adicionou-se como agente tensoativo o polissorbato 80 na concentração de 1 $\mathrm{mg} / \mathrm{ml}$ para facilitar a dispersão e inativar a ação antimicrobiana do parabeno. 
A partir da primeira diluição $10^{-1}$, preparou-se diluições decimais sucessivas até a diluição de $10^{-7}$ com o mesmo diluente.

Semeio: Foi utilizado o método quantitativo de contagem de UFC (Unidades Formadoras de Colônias), com semeio em superfície por distensão com alça de Drigalsky. Para cada fator de diluição foram tomadas duas placas de ágar caseína-soja, preparadas previamente, conforme orientação do fabricante. Em cada placa foi adicionado 0,1ml de cada diluição e espalhado com o auxilio da alça. As placas foram mantidas na capela de fluxo laminar por 15 minutos até a completa absorção da alíquota na superfície do ágar.

Após os 15 minutos as placas foram cultivadas em estufa bacteriológica calibrada com temperatura de $35,5^{\circ} \mathrm{C}$ onde foram mantidas por 4 dias. Em todos os testes foram utilizadas placas sem semeio como controle negativo.

Contagem de Unidades Formadoras de Colônicas (UFC): Foram selecionadas as placas semeadas com alíquotas das diluições $10^{-6}$ e $10^{-7}$ por apresentarem números de colônias contáveis. O número de UFC total das placas foi determinado usando-se a seguinte equação:

Equação 4

UFC = Número de colônias X Fator de diluição/0,1

O número total de UFC foi determinado pela média aritmética dos valores de cada placa das duplicatas das diluições selecionadas.

\section{$\underline{\text { Avaliação da atividade antioxidante }}$}

A avaliação da capacidade antioxidante in vitro da emulsão submetida ao estudo de estabilidade, assim como das soluções oleosas foi realizada em triplicata e determinada pelo método ABTS (ácido 2,2'-azinobis-3-etilbenzotiazolina-6-sulfónico) (RE et al, 1999) com modificações.

O radical ABTS foi inicialmente formado a partir da reação de $7 \mathrm{nM}$ de ABTS com 2,45nM de perssulfato de potássio, incubado em temperatura ambiente e protegido da luz por no mínimo 16h. Após esse período, uma alíquota do radical foi diluída em etanol $\left(96^{\circ} \mathrm{GL}\right.$, P.A.) até obtenção de uma solução com densidade óptica de aproximadamente 0,700 , a um comprimento de onda de $754 \mathrm{~nm}$.

Compostos antioxidantes presentes no óleo Rosa Mosqueta foram extraídos das formulações em teste (E30, S30 e S100), adicionando-se solução de acetona e etanol na 
proporção 80:20 (v/v), obtendo-se soluções com a concentração de 1000 mg/mL submetidas a centrifugação em rotação de $15000 \mathrm{rpm}$ por 10 minutos a $25^{\circ} \mathrm{C}$.

Alíquota de $20 \mu \mathrm{L}$ de solução extrativa obtida após centrifugação foi adicionada à 980 $\mu \mathrm{L}$ de solução etanólica de ABTS com absorbância $\left(\mathrm{A}_{0}\right)$ previamente determinada. Após homogeneização em vórtex, a solução era acondicionada em microcubeta e mantida em repouso ao abrigo da luz por 6 minutos dentro do espectrofotômetro até leitura $\left(\mathrm{A}_{\mathrm{f}}\right)$ com absorbância determinada de $0,754 \mathrm{~nm}$. Apenas os valores que apresentaram densidade ótica em torno de $50 \%$ do valor obtido para a solução do reativo ABTS (cerca de 0,700 ), foram consideradas.

Os resultados foram expressos em Capacidade Antioxidante Total Equivalente ao Trolox (TEAC $\mu \mathrm{M}$ ). Os cálculos foram realizados de acordo com a equação ilustrada a seguir.

Equação 5

$$
\text { Inibição do radical }(\%)=\left(1-\mathrm{A}_{\mathrm{f}} / \mathrm{A}_{0}\right) \times 10
$$

Onde $\mathrm{A}_{\mathrm{f}}$ corresponde a absorbância de cada amostra analisada e $\mathrm{A}_{0}$ a absorbância do radical.

A concentração equivalente em Trolox foi calculada a partir da equação da reta ilustrada no gráfico 1, estabelecida através de soluções padrão de trolox.

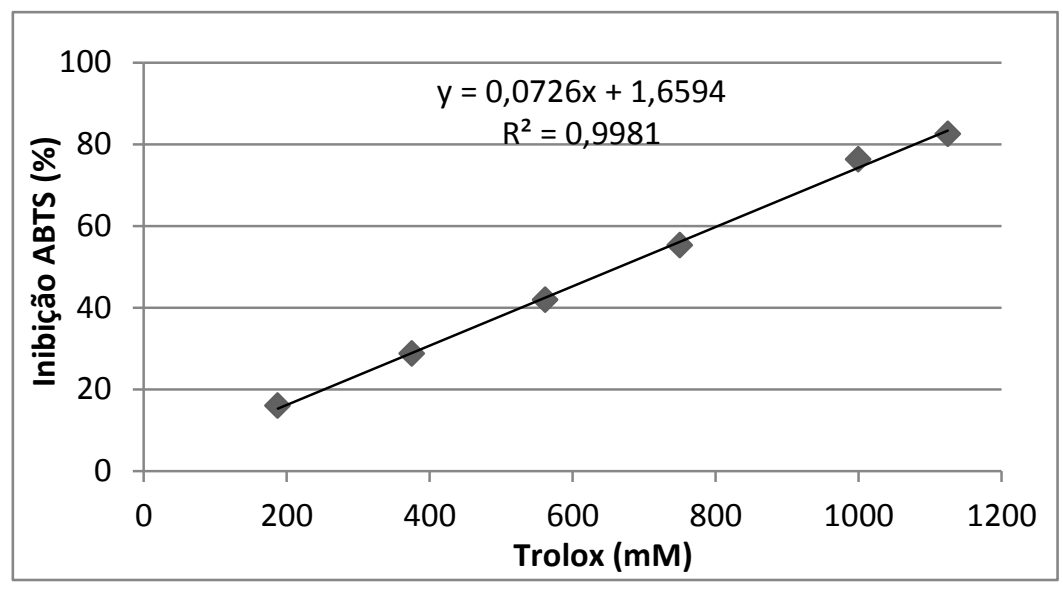

Gáfico 1 Determinação da curva-padrão de trolox. Brasília, 2016.

A correção da diluição foi calculada de acordo com a equação 6. 
$\boldsymbol{T E} \boldsymbol{A C}(\mu \mathbf{M})$ correção diluição $=\frac{(\operatorname{TAEC}(\mu \mathrm{M}) \times \text { fator de diluição })}{\text { Concentração solução extrativa }}$

\section{$\underline{\text { Avaliação do teor de betacaroteno }}$}

A avaliação da estabilidade química das soluções oleosas de Rosa Mosqueta (S30 e S100) também foi dimensionada a partir da análise do teor de betacaroteno. Esta substância foi selecionada para análise por apresentar capacidade anti-oxidante amplamente reconhecida, como também devido a disponibilidade de metodologia analítica, simplificando a execução da análise (Molica, 2015).

A identificação e quantificação de betacaroteno foram realizadas através de cromatografia líquida de alta eficiência (CLAE). A separação foi realizada em uma coluna analítica de fase reversa revestida de sílica (C18) de aproximadamente $35 \mu \mathrm{m}$ de diâmetro. A detecção das frações de betacaroteno foi realizada a 450nm.

Alíquotas de 0,5g de solução S100 foram solubilizadas em $1 \mathrm{~mL}$ de solução de diclorometano:acetona na proporção 80:20 (v/v) enquanto alíquotas de 0,5g de solução S30 foram solubilizadas em $0,5 \mathrm{~mL}$ da mesma solução orgânica. Uma fração de $10 \mu \mathrm{L}$ de cada amostra, em triplicata, foi injetada a uma velocidade de 0,8 $\mu$ L.min-1 e eluídas em fase móvel composta por acetonitrila:diclorometano nas proporções 70:30 (v/v) em corridas de 13 minutos. Os picos foram identificados pela comparação com o tempo de retenção do padrão de $\beta$-caroteno, $\geq 95 \%$ de pureza (Sigma Aldrich, EUA) e a quantificação foi baseada na curva analítica construída a partir da validação do método com o padrão (cf. Gráfico 2).

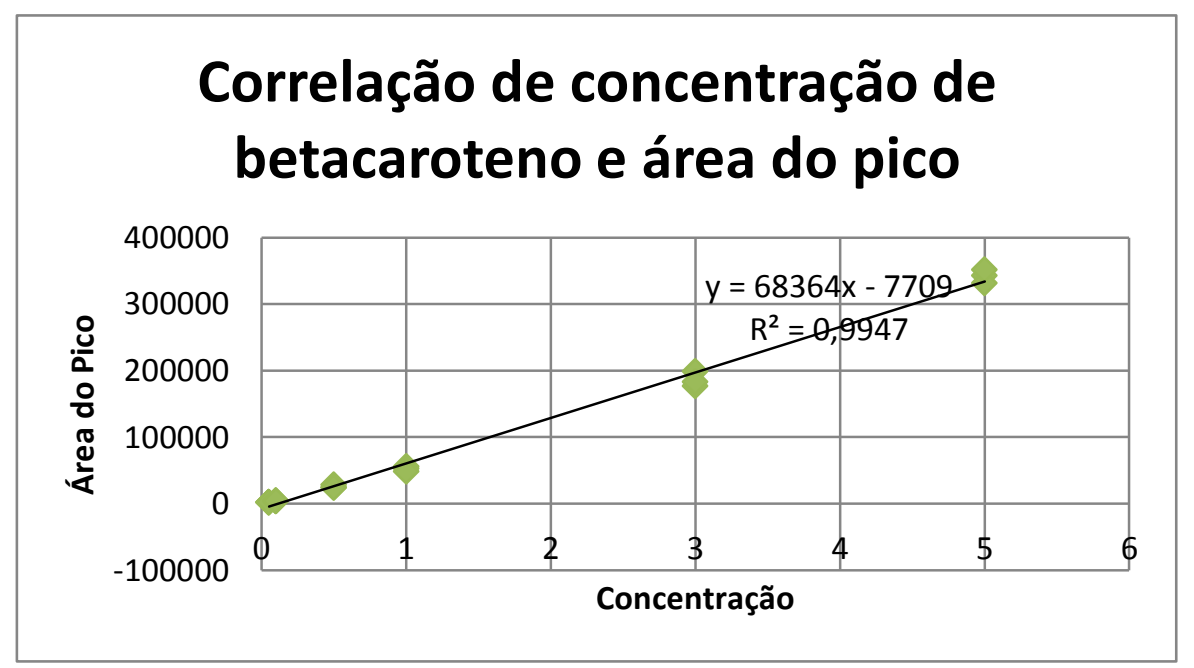

Gáfico 2 Correlação das concentrações do padrão de betacaroteno e área do pico, equação da reta e correlação de Pearson. Brasília, 2016. 


\section{$\underline{\text { Análise estatística }}$}

Os dados foram analisados no programa SPSS for Windows 20.0 e os gráficos e figuras construídas no programa GraphPad Prism 7.0. A normalidade da amostra foi definida por meio do teste Shapiro-Wilk. Dados multivariados foram submetidos a teste estatístico Anova ou Anova Two-Way com pós-teste de Benjamini, Krieger e Yekutieli. A análise qualitativa foi realizada utilizando-se o Teste Exato de Fisher. Diferenças entre médias foram consideradas significativas quando $\mathrm{p} \leq 0,05$.

\section{Resultados e Discussão}

Os três lotes elaborados da emulsão E30 (A, B e C) apresentaram-se consistentes e de coloração branca-opaca, sem odor característico do óleo de Rosa Mosqueta ou de ranço. A análise estatística mostrou Alpha de Cronbach de 0,99, indicando que houve boa repetibilidade entre as triplicatas com pouca variação dos resultados entre os lotes.

Ao longo dos dias de observação, notou-se odor de ranço, tanto nas amostras da emulsão E30 quanto no óleo de Rosa Mosqueta (S100), atingindo maior intensidade de odor aos 90 dias de armazenamento em condições climáticas controladas. Alterações evidentes de cor e consistência foram observadas a partir do $60^{\circ}$ dia e todas as amostras de emulsão E30 assumiram coloração creme opaca com manchas amareladas, intensificando essas características no $90^{\circ}$ dia (cf. Fig. 8). 

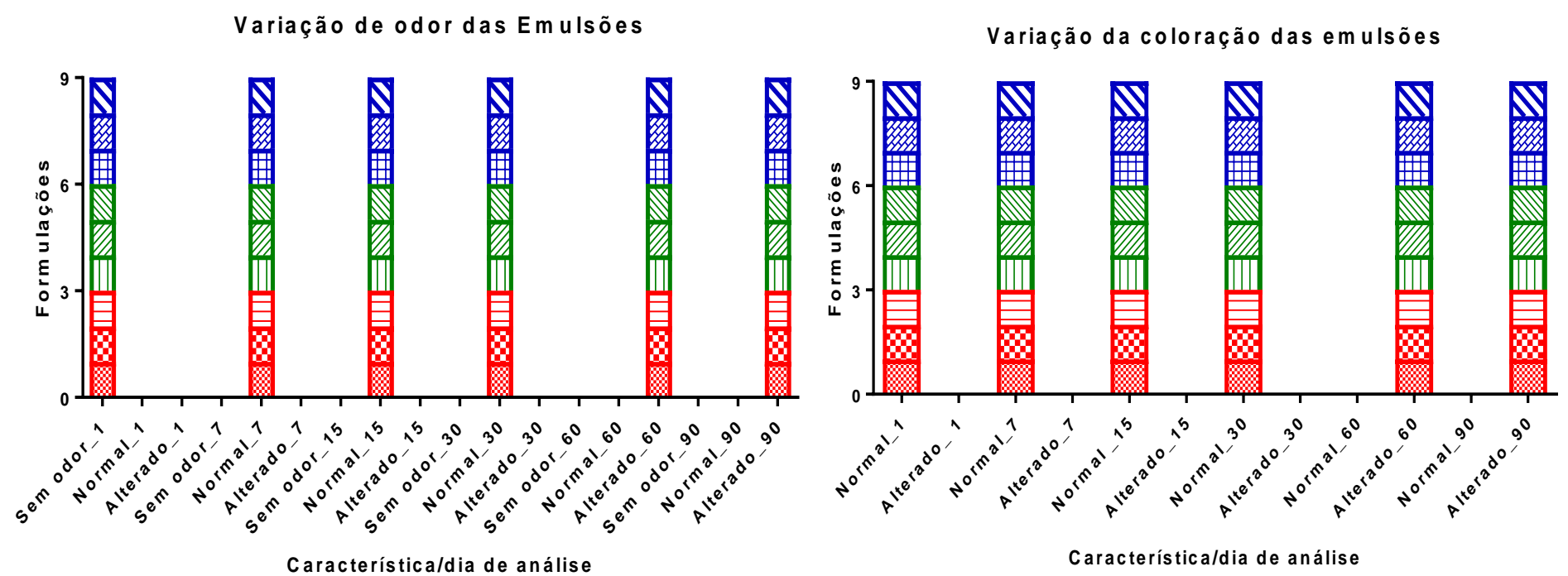

Característica/dia de análise

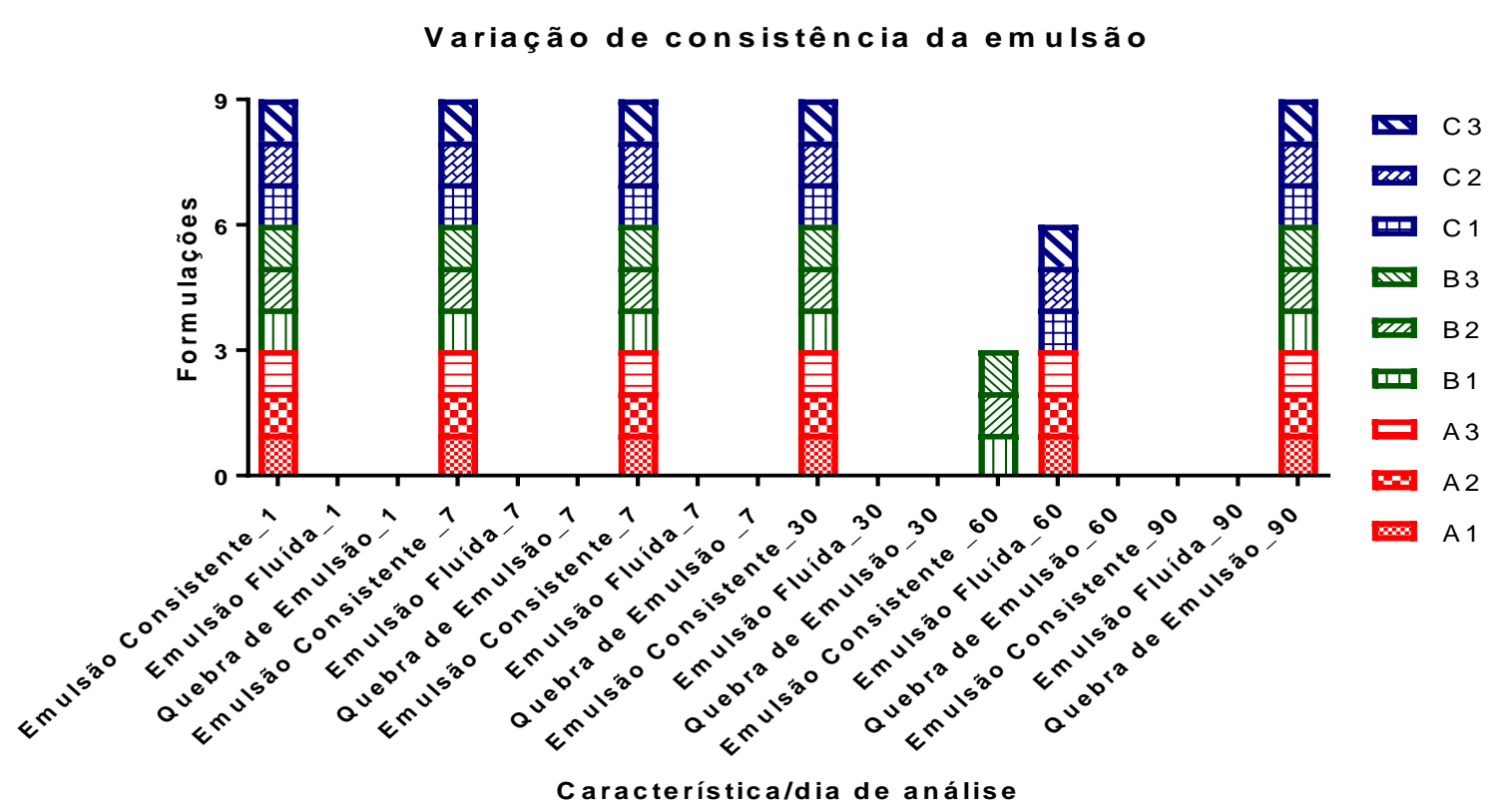

Figura 8 Demonstrativo da avaliação de cor, odor e consistência das emulsões durante os dias de análise. Brasília, 2016.

As amostras da emulsão E30 apresentaram redução da consistência no D60, porém mais intenso nas amostras A e C. No dia 90, todas apresentaram consistência fluida evidenciando quebra de emulsão. $\mathrm{O}$ estudo de espalhabilidade confirmou essa tendência mostrando aumento brusco do índice de espalhabilidade no dia 90, mais acentuado no lote $\mathrm{C}$ (cf. Fig. 9). 

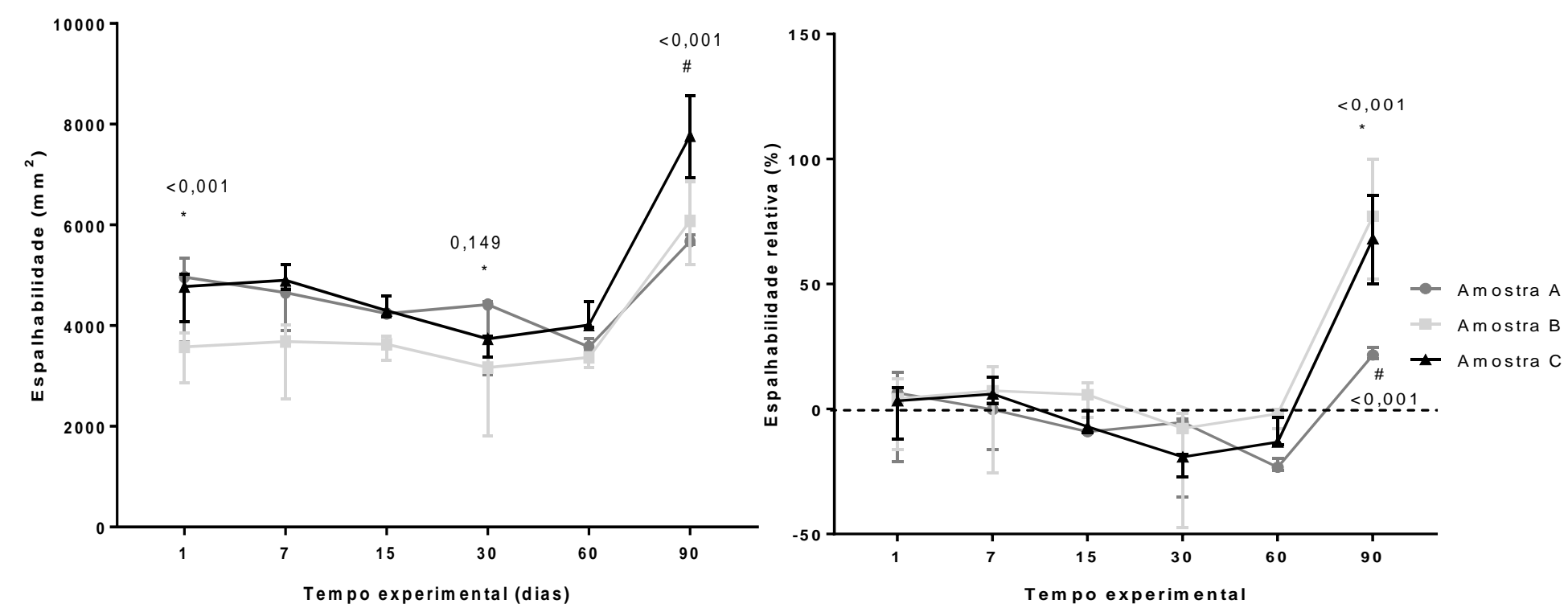

Figura 10 Evolução do índice de espalhabilidade e espalhabilidade relativa (\%) das emulsões avaliadas ao longo dos dias de armazenamento. Brasília, 2016. TesteAnova Two-Way com pós-teste de Benjamini, Krieger e Yekutieli. * diferença entre amostras A e B; \# Diferenças entre amostras A e C.

A diferença de massa nos dias de armazenamento em relação ao dia inicial é apresentada na figura 10 a seguir. A emulsão C apresentou menor perda de massa ao longo do tempo, embora não tenha sido identificada diferença significativa entre as amostras ( $c f$ Fig. 10-B). Também não foi encontrada correlação entre o índice de espalhabilidade e perda de massa (cf Fig. $10-\mathrm{A})$.

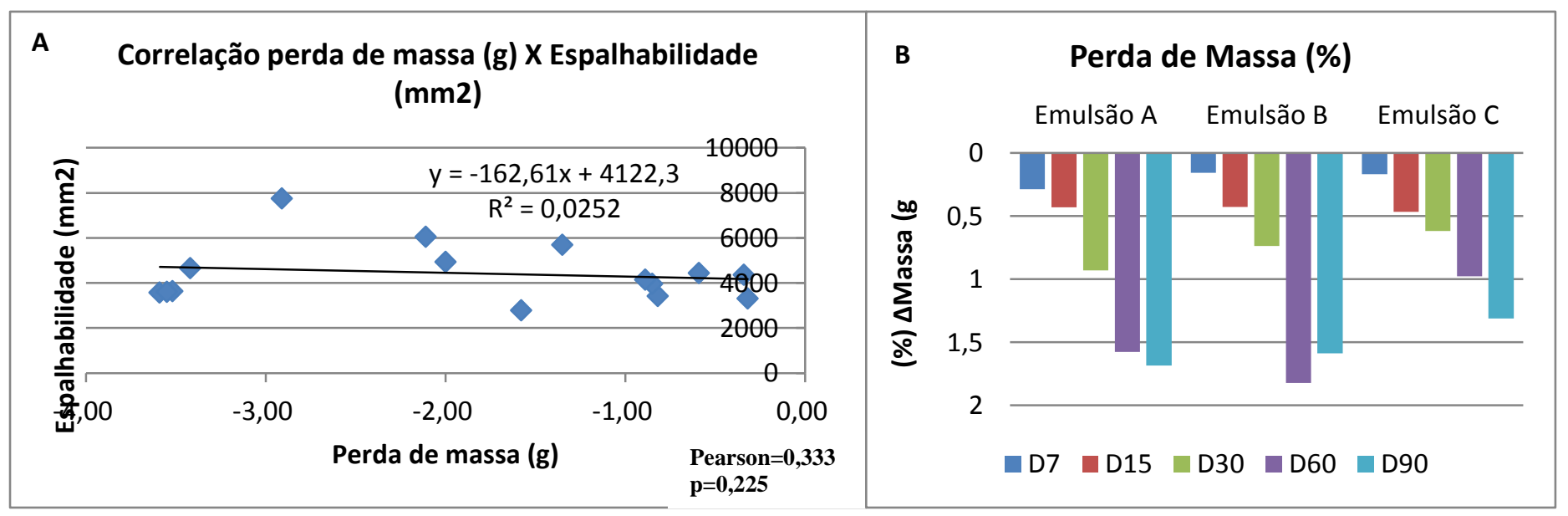

Figura 11 A - Correlação de Pearson para perda de massa e espalhabilidade; B - Esquema de perda de massa das amostras ao longo dos dias de armazenamento. Brasília, 2016. Teste Anova, p=0,777. 
As características organolépticas após centrifugação sofreram alteração apenas no $90^{\circ}$ dia de estudo, quando ocorreu quebra de emulsão nos três lotes de emulsão E30 analisados. Quanto às soluções oleosas, tanto o óleo de Rosa Mosqueta puro quanto o óleo a 30\% mantiveram suas características organolépticas ao longo dos dias, com intensificação do odor de ranço e formação de precipitado no dia 90. O quadro 3 mostra as características físicoquímicas das três emulsões ao longo dos dias de análise.

Quadro 3 Características organolépticas das emulsões ao longo dos dias de armazenamento. Brasília, 2016.

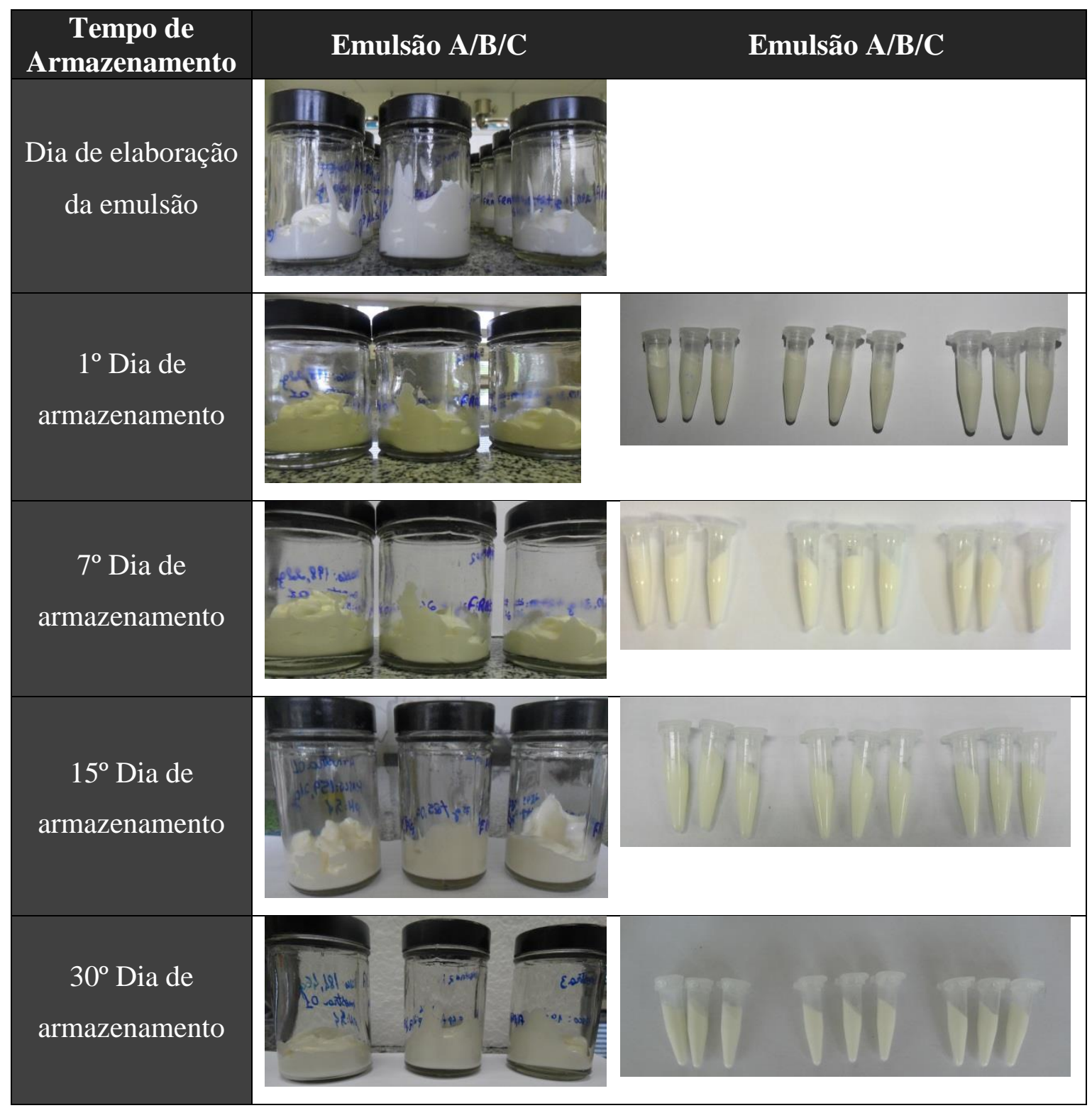




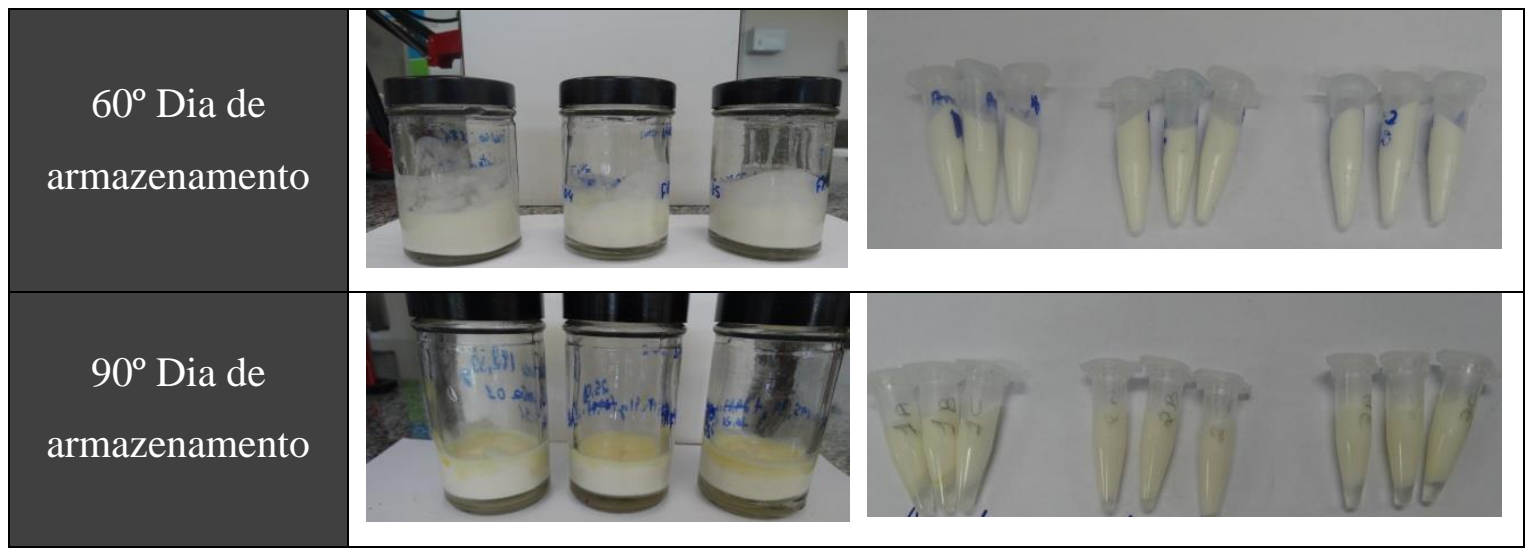

Houve uma tendência de aumento do $\mathrm{pH}$ das amostras, mais acentuada na amostra $\mathrm{C}$, até o $30^{\circ}$ dia de avaliação, sofrendo queda progressiva até o dia 90 ( $c f$ Fig. 11). A redução do $\mathrm{pH}$ foi positivamente correlacionada com a perda de massa das amostras ao longo dos dias ( $c f$ Fig. 12). Embora tenha sido encontrada correlação positiva entre $\mathrm{pH}$ e espalhabilidade $(\mathrm{p}<0,001)$, essa correlação foi baixa ( $c f$ Fig. 13).

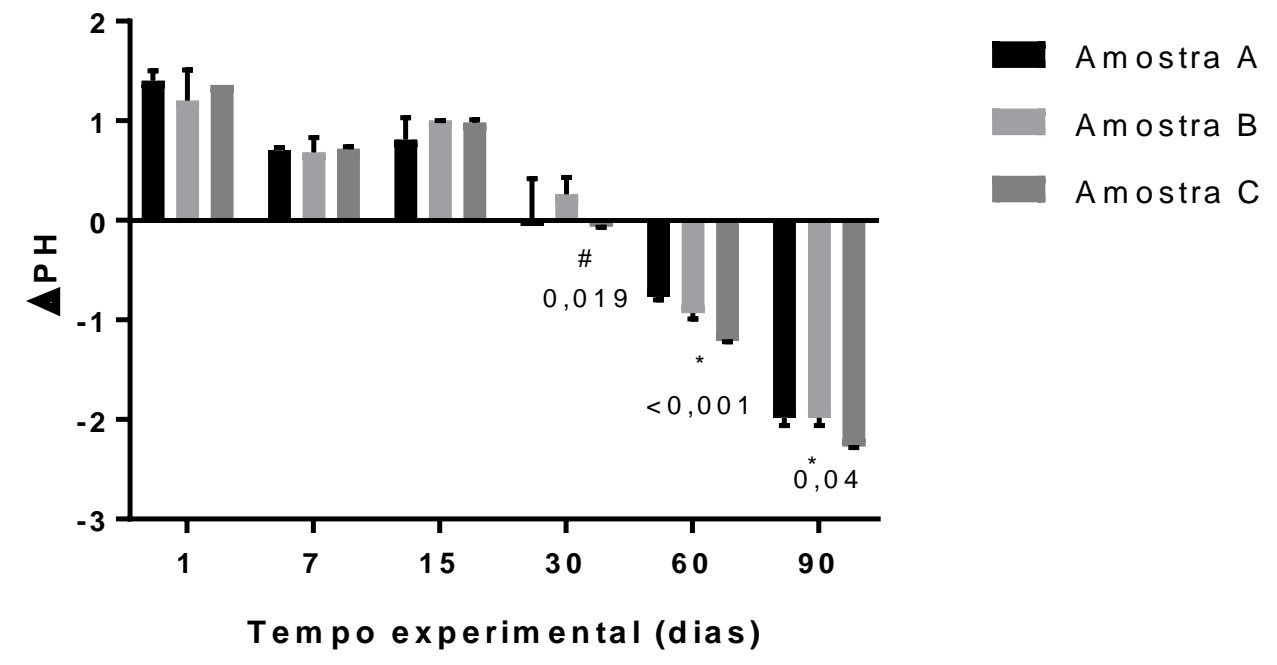

Figura 12 Diferenças de pH entre as amostras e ao longo dos dias de armazenamento. Brasília, 2016. TesteAnova Two-Way com pós-teste de Benjamini, Krieger e Yekutieli. * diferença entre amostras A e B; \# Diferenças entre amostras A e C. 

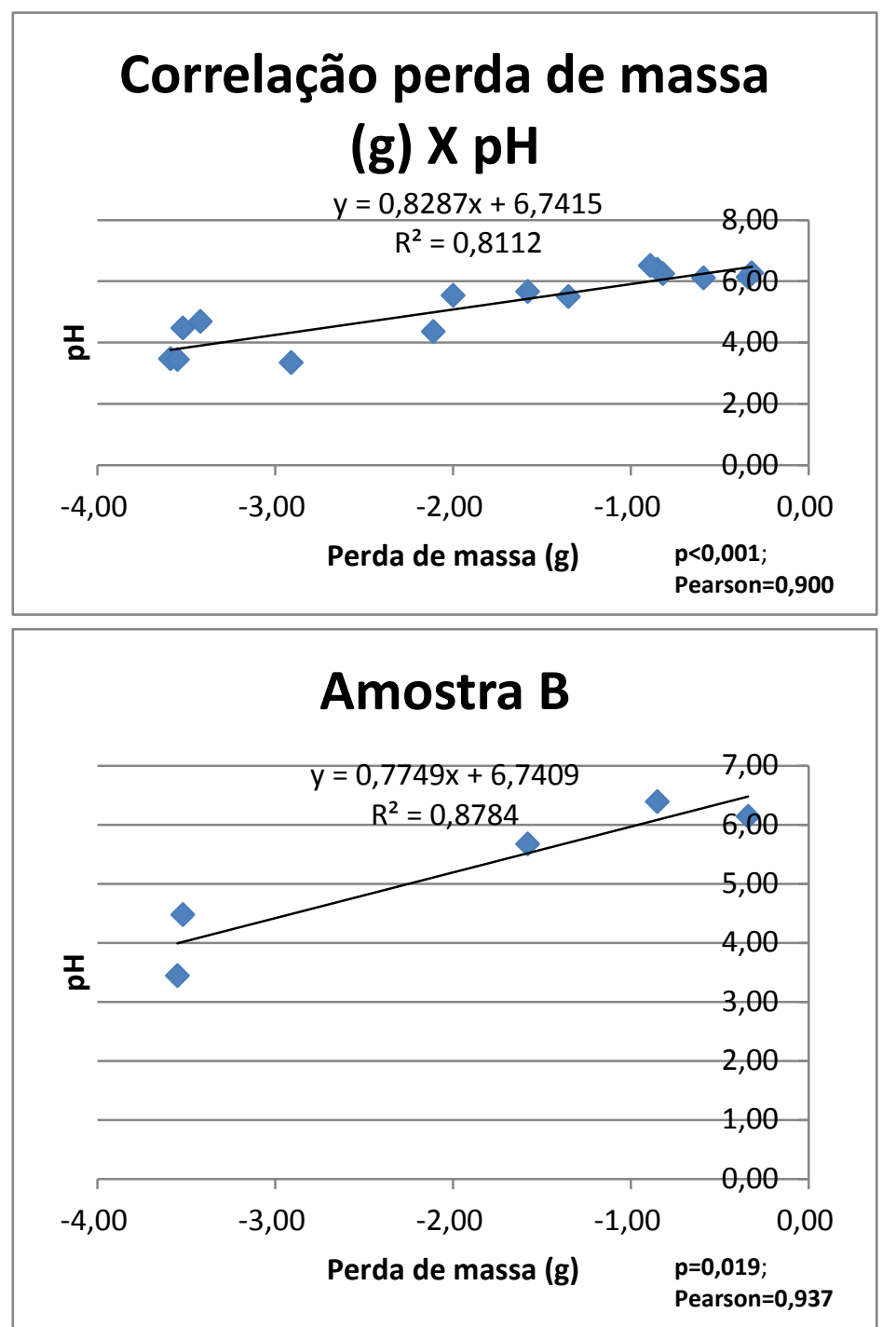
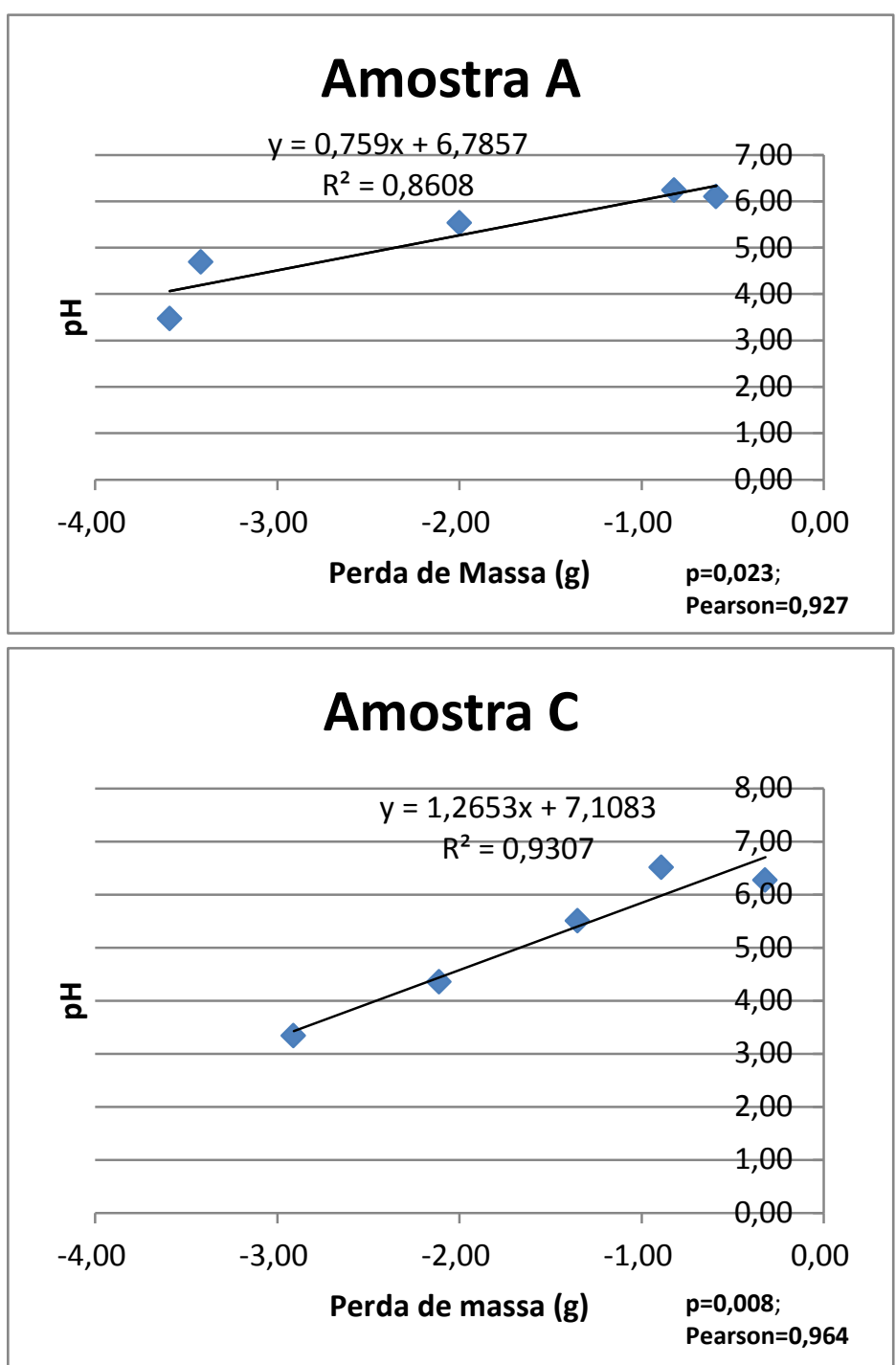

Figura 13 Correlação entre perda de massa (g) e pH longo dos dias de análise. Correlação de Pearson. Brasília, 2016.

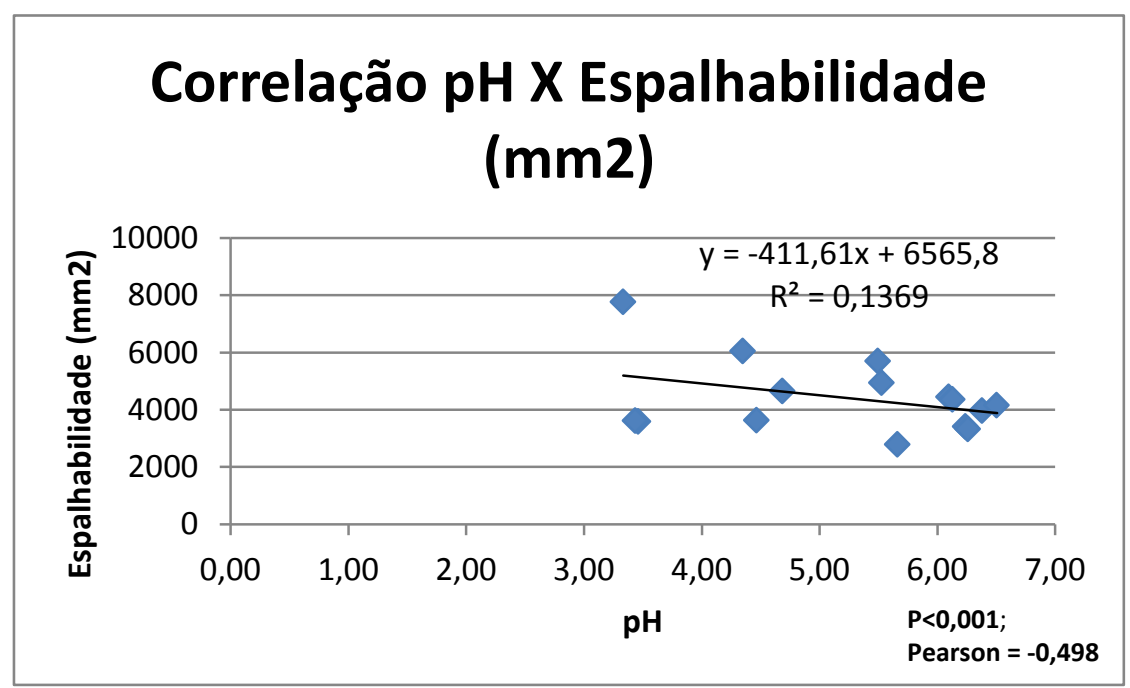

Figura 14 Correlação entre pH e esplhabilidade das amostras ao longo dos dias de análise. Correlação de Pearson. Brasília, 2016. 
A capacidade antioxidante in vitro das emulsões e dos óleos mostrou tendência de queda ao longo dos dias de análise não se observando capacidade antioxidante nas amostras de óleo no dia 90 ( $c f$ Fig. 14 - A). Comparado ao óleo puro, as emulsões mostraram maior capacidade antioxidativa ao longo dos dias, com queda acentuada após o dia 90 ( $c f$ Fig. 14 B). A amostra de óleo a $30 \%$ mostrou equivalência no grau de capacidade antioxidativa em relação ao óleo puro, mantida ao longo dos dias de análise.
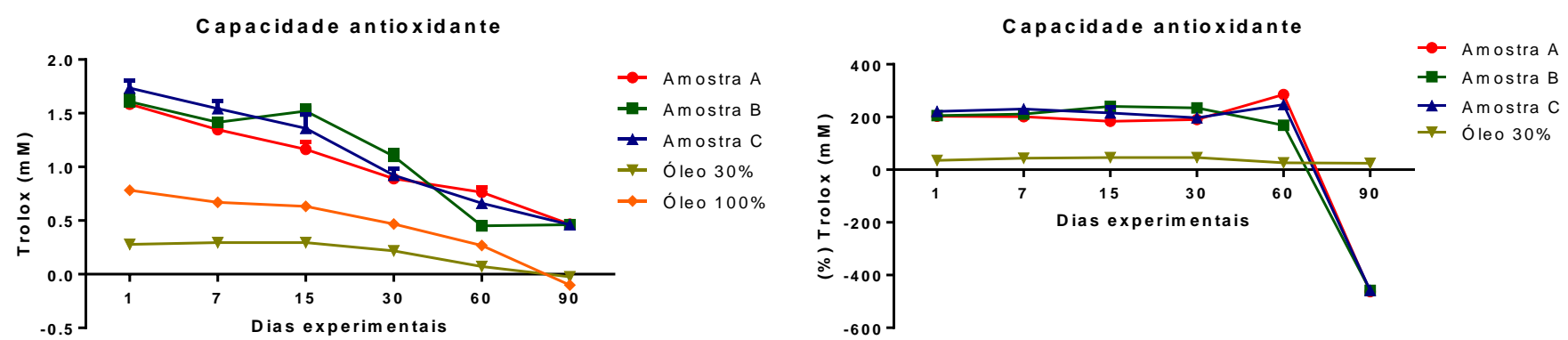

Figura 15 Capacidade antioxidativa in vitro nas emulsões e amostras de óleo ao longo dos dias de armazenamento. B Comparação (\%) capacidade antioxidativa das emulsões e do óleo a 30\% comparado ao óleo puro, Brasília, 2016. TesteAnova Two-Way com pós-teste de Benjamini, Krieger e Yekutieli. $p<00,1$ entre cremes e óleos.

A capacidade antioxidativa das amostras dos três lotes da emulsão E30 submetidas ao estudo de estabilidade acelerada mostraram forte correlação positiva com o $\mathrm{pH}$, apresentando máxima capacidade antioxidante em situação de $\mathrm{pH}$ mais elevado ( $c f$ Fig.15) e fraca correlação negativa com a espalhabilidade das amostras ( $c f$ Fig. 16).
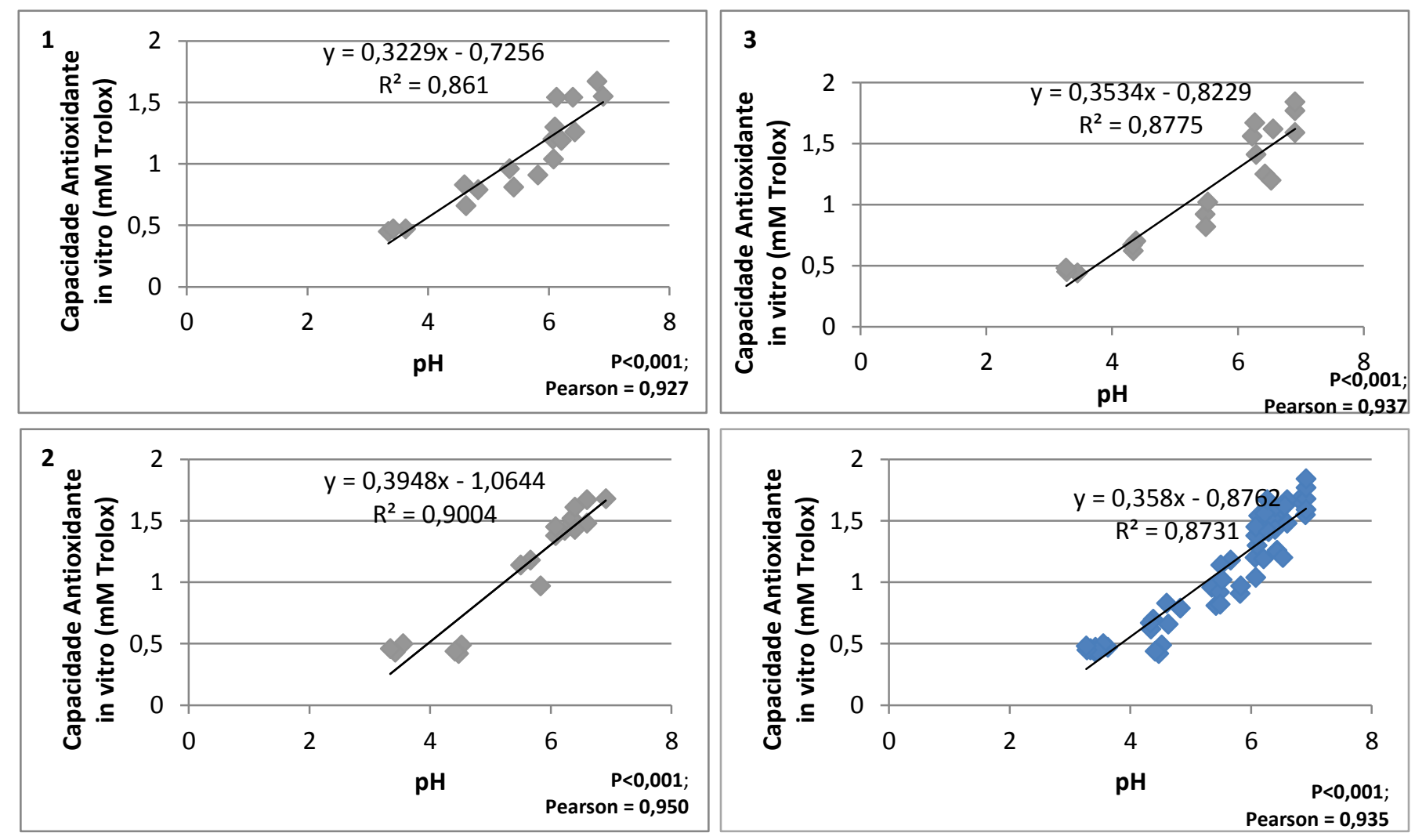

Figura 16 Correlação entre pH e capacidade antioxidante in vitro ( $\mu \mathrm{M}$ Trolox) das emulsões A (1), B (2) e C (3) ao longo dos dias de análise. p<0,001, Correlação de Pearson. Brasília, 2016. 


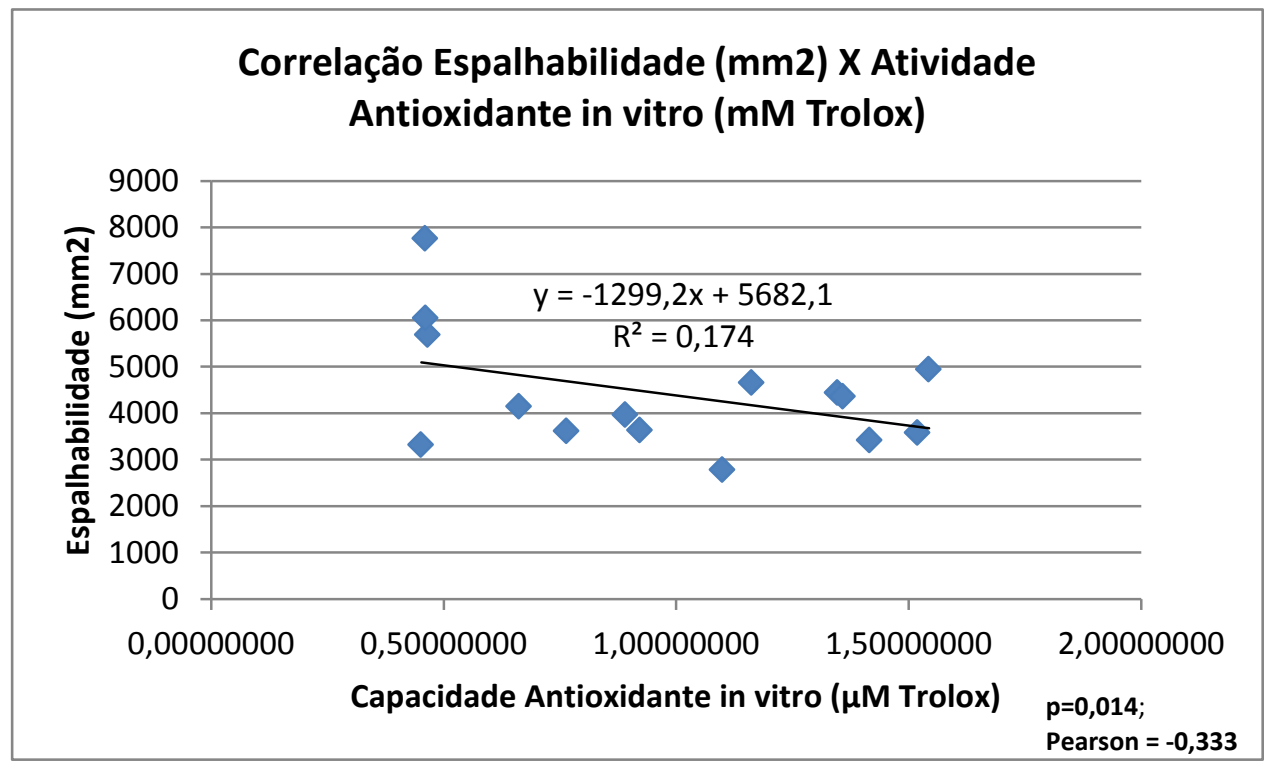

Figura 17 Correlaçao de Pearson entre espalhabilidade ( $\mathrm{mm} 2)$ e capacidade antioxidante in vitro (mM Trolox) nas amostras estudadas ao longo dos dias. Brasília, 2016.

O doseamento de betacarotenos nas amostras de óleo mostrou queda acentuada da concentração a partir do $30^{\circ}$ dia de armazenamento ( $c f$ Fig. 17 - A). A concentração de betacarotenos na amostra de óleo $30 \%$ foi de aproximadamente um terço da concentração encontrada no óleo puro. Foi observado, porém, que essa concentração chegou a $50 \%$ da concentração do óleo puro no $30^{\circ}$ dia ( $c f$ Fig. 17 - B), quando houve queda brusca até não ser possível identificar betacaroteno por meio do método.
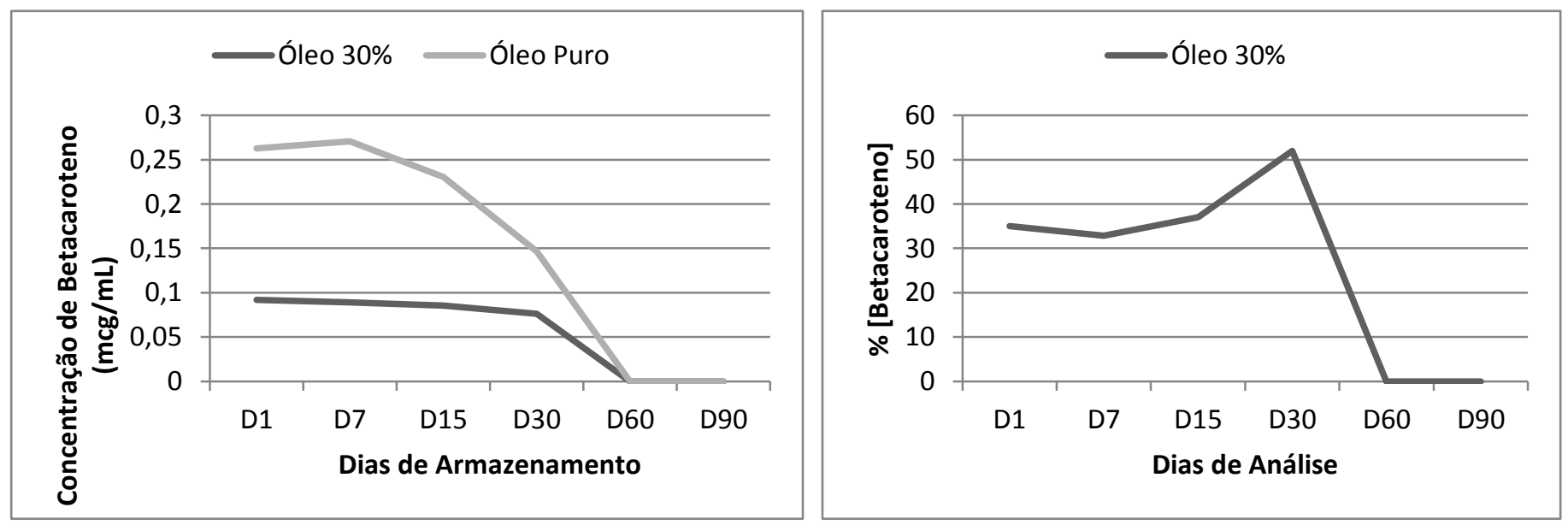

Figura 18 A - Concentração de Betacaroteno nas amostras de óleo ao longo dos dias de armazenamento. B - Comparação da dosagem de betacaroteno no óleo a 30\% comparado ao óleo puro, Brasília, 2016. Teste Anova Two-Way com pós-teste de Benjamini, Krieger e Yekutieli, p<0,001.

Quanto ao estudo microbiológico, todas as amostras apresentaram crescimento bacteriano e fúngico nas primeiras $24 \mathrm{~h}$ até o $7^{\circ}$ dia de avaliação a ponto de prejudicar a contagem de UFC. A amostra E30-A apresentou menor contaminação em todos os tempos de 
avaliação. Ao longo dos dias de análise, foi observado redução do crescimento de microorganismos a partir do $15^{\circ}$ dia em todas as amostras ( $c f$. Fig. 18). O cálculo de UFC foi realizado no dia 60 nas diluições $10^{-5}$, pelo Método do Número Provável (NMP), cujos resultados podem ser visualizados na Tabela 4.

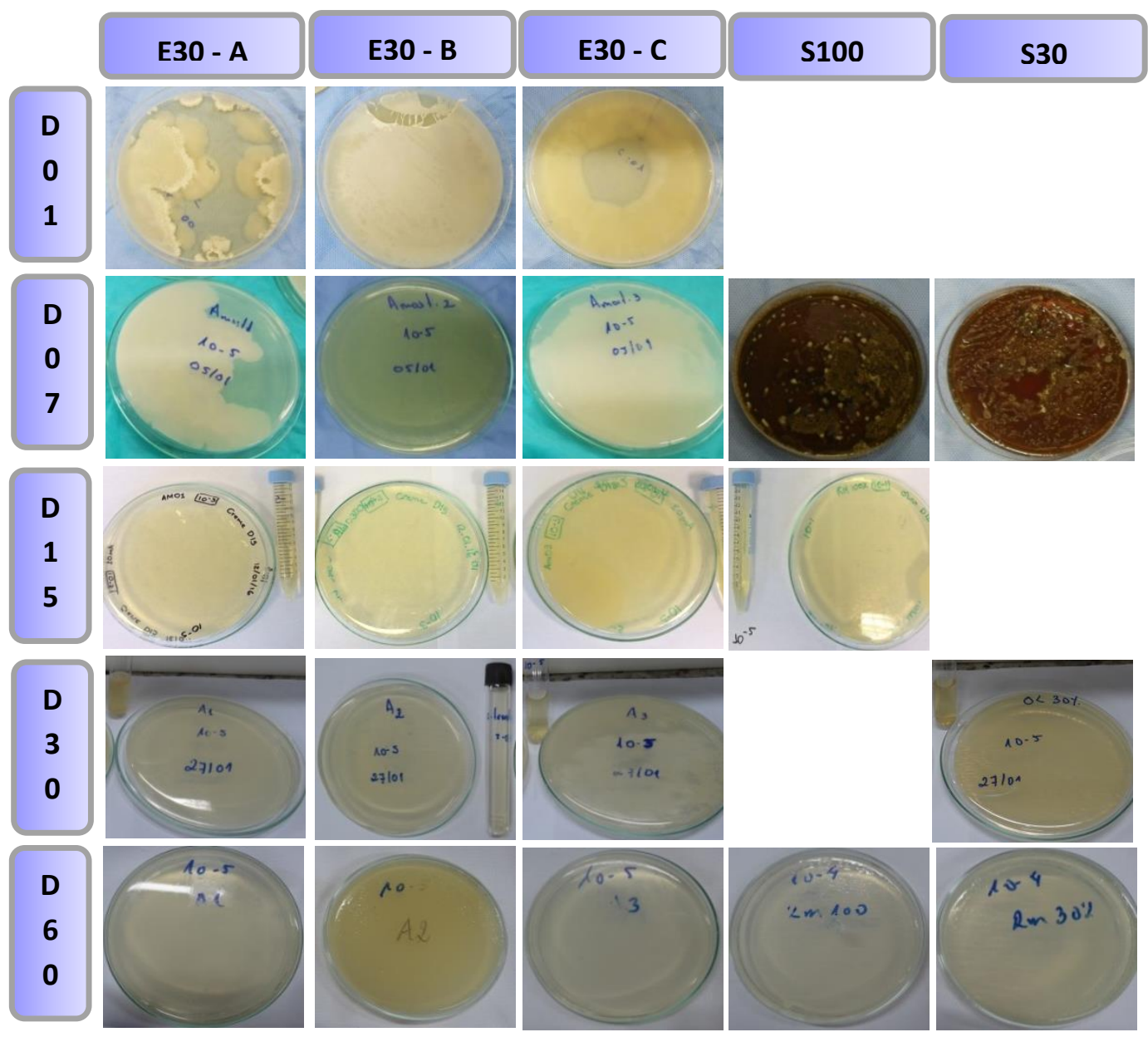

Figura 19 Apresentação de culturas em placas de petri das amostras analisadas ao longo dos dias de armazenamento, Brasília, 2016. Legenda: E30-A: emulsão 30\%, triplicata A; E30-B: emulsão 30\%, triplicata B; E30-C: emulsão 30\%, triplicata C; S100 - óleo de Rosa Mosqueta 100\%; S30 Solução de óleo de Rosa Mosqueta $30 \%$.

Tabela 4 NMP de UFC por triplicatas da emulsão elaborada após 60 dias de armazenamento. Brasília, 2016.

\begin{tabular}{lc}
\hline Amostra & UFC (NMP/mL) \\
\hline Triplicata A & $2,3.10^{-5}$ \\
Triplicata B & $6,0.10^{-5}$ \\
Triplicata C & $7,0.10^{-5}$ \\
\hline
\end{tabular}


As emulsões são misturas termodinamicamente instáveis de líquidos imiscíveis, estabilizada por um agente emulsificante, podendo conter ativos biológicos, naturais ou sintéticos, dissolvidos ou dispersos em suas fases (Thompson, 2006). Por esse motivo, agentes emulgentes - Tween 20, Álcool cetoestearílico etoxilado e Carbômero 940 - são incorporados à formulação visando otimizar a estabilidade do sistema ao proporcionar emulsificação e aumento da viscosidade (Frange \& Garcia, 2009). Contudo, a estabilidade de uma emulsão também depende da interação entre as matérias primas utilizadas e as condições de armazenamento.

O estudo de estabilidade acelerada foi realizado com a emulsão contendo a maior concentração possível de óleo de Rosa Mosqueta (E30) a ser incorporada na formulação e que permitiu a obtenção de um produto esteticamente agradável. Essa escolha foi baseada na análise organoléptica, que consiste no primeiro teste empregado no controle de qualidade de produtos farmacêuticos por meio da descrição dos aspectos físicos tais como cor, consistência e odor. Essa análise visual é uma prova analítica simples, porém necessária para avaliação da integridade física e estética do produto elaborado e serve para nortear o manipulador na escolha do produto com maior tempo de prateleira ou prazo de validade (Gil, Matias \& Orlando, 2010).

A emulsão E30 manteve sua integridade física nos primeiros 30 dias de armazenamento sob condições de temperatura e umidade que favoreciam a instabilidade da formulação. Após este período iniciou-se um processo gradual de degradação evidenciado por alterações na cor, odor e consistência até completa separação de fases da emulsão.

Os testes de centrifugação e de espalhabilidade permitem identificar, de forma simples e rápida, possíveis instabilidades físicas e alterações reológicas que possam atingir as formulações.

Todas as amostras dos distintos lotes da emulsão E30 apresentaram estabilidade quando submetidas à centrifugação, ocorrendo quebra da emulsão apenas no dia 90, quando as amostras já mostravam sinais organolépticos de instabilidade. Quando a emulsão é submetida à centrifugação, a separação de fases pode ocorrer. O aumento da gravidade gerado pela rotação provoca aproximação e fusão das gotículas da fase interna, levando à cremeação ou coalescência da emulsão até total separação de fases, permitindo rápida comparação de informações sobre as propriedades físicas das distintas emulsões (Morais, 2006).

A espalhabilidade avalia características físicas relacionadas à manipulação e aplicação do produto. Do ponto de vista clínico é desejável uma emulsão de fácil aplicação no leito da ferida ao mesmo tempo em que sua consistência possa garantir oclusão no local aplicado. Por 
outro lado, a fluidez deve permitir a retirada do produto sem trauma ao frágil tecido neoformado. Até o dia 60 de armazenamento, a emulsão E30 mostrou características físicas adequadas para fácil aplicação e retirada do leito da lesão. O aumento significativo da espalhabilidade após o dia 60 está relacionado à quebra das emulsões no dia 90. Esse aumento gradual da espalhabilidade acompanhou a redução do $\mathrm{pH}$ ao longo do tempo, indicando degradação da amostra.

A avaliação microbiológica de uma formulação busca estabelecer parâmetros de segurança e qualidade para o usuário. Contaminações de formulações podem acarretar alterações físico-químicas e consequente instabilidade do produto, além de riscos de infecção para o usuário (Brasil, 2010). Apesar do cuidado durante o preparo das emulsões, foi observado crescimento bacteriano e fúngico de espécies comensais presentes no ambiente, o que pode indicar contaminação durante a manipulação, tanto nas formulações O/A quanto nas soluções oleosas. Entretanto, houve decréscimo da colonização das amostras ao longo do tempo, não parecendo haver relação com a instabilidade das emulsões e redução do pH observados. Contudo, a alta carga microbiológica inicial pode ter acelerado a degradação do óleo e abreviado a estabilidade das emulsões.

A triplicata E30-A apresentou menor crescimento microbiológico em todos os dias de análise. O cálculo de UFC's no dia 60 ainda se manteve acima do limite de segurança de 200.000 para diluições $10^{-5}$ preconizado pela Anvisa. A diferença significativa de carga microbiana da triplicata $\mathrm{A}$ em relação às demais amostras pode estar relacionado ao manipulador.

A redução da carga microbiológica das amostras pode estar relacionada à eficiência do sistema conservante da formulação, ou mesmo a alguma atividade antimicrobiana do óleo, visto que as soluções oleosas apresentaram o mesmo comportamento. Hakansson et al (2006), Chrubasik et al (2008) e Patel (2012) descreveram uma possível atividade antimicrobiana do óleo de Rosa Mosqueta, ainda pouco elucidada.

Embora não seja requerida a esterilidade de produtos tópicos, há um limite de contaminação microbiológica que deve ser observado. Apesar da redução da carga microbiana, nossas amostras mantiveram índices acima dos permitidos pela Farmacopéia Brasileira (Brasil, 2010).

$\mathrm{O}$ pH de uma formulação permite avaliar a estabilidade dos ingredientes, eficácia dos princípios ativos, segurança do produto e compatibilidade com a via de administração (Anvisa, 2004). Pequenas variações no pH indicam maior estabilidade físico-química. 
$\mathrm{O} \mathrm{pH}$ dos três lotes elaborados mantiveram-se compatível com o $\mathrm{pH}$ da pele (que varia entre 4,0-6,5) (Savian et al, 2011) até o $60^{\circ}$ dia de armazenamento, variando entre 4,3-4,8. A alteração de $\mathrm{pH}$ foi mais evidente no dia 90 quando caiu abaixo de 3,5 em todas as emulsões analisadas, tornando-as impróprias para uso dermatológico. Esse aumento de acidez parece estar relacionado com a degradação química do óleo, já que a capacidade antioxidante e concentração de betacaroteno mostraram o mesmo padrão de queda ao longo do tempo nas emulsões e nas soluções oleosas.

Em estudo de estabilidade acelerada de emulsões óleo em água, Frange e Garcia (2009) verificaram variação significativa de pH nas amostras armazenadas em estufas. Da mesma forma, Savian et al (2011), em estudo de estabilidade preliminar de emulsões O/A sob condições variadas de armazenamento identificaram redução de pH nas amostras mantidas sob temperaturas de $40^{\circ} \mathrm{C}$. Ambos os autores concluíram que a alteração do $\mathrm{pH}$ foi ocasionada por degradação de compostos bioativos contidos nos óleos, já que o aquecimento favorece a hidrólise de triglicerídeos constituintes da fração oleosa, ocasionando a formação de ácidos graxos livres que resultam em aumento da acidez e consequente mudanças físico-químicas da emulsão (Driscol, 2001).

A capacidade antioxidante neste estudo variou entre 0,2 e 1,0 $\mu \mathrm{M}$ Trolox. $\mathrm{mL}^{-1}$ para as soluções oleosas e 0,5 e 2,0 $\mu \mathrm{M}$ Trolox. $\mathrm{mL}^{-1}$ para as emulsões formuladas a partir do óleo. Esses valores corroboram os achados de Roman (2013) que giram em torno de 60 a $120 \mu \mathrm{M}$ Trolox $100 \mathrm{~g}^{-1}$ de casca do fruto seco (Roman, 2013).

A capacidade antioxidante de óleos vegetais deve-se à presença de diversos componentes como tocóis, carotenoides, compostos fenólicos e esteróis que frequentemente agem em sinergismo (Castelo-Branco e Torres, 2011). Nosso estudo mostrou queda da capacidade antioxidativa das amostras à medida que o pH se tornou mais ácido. Houve queda da concentração de betacarotenos nas soluções oleosas, podendo indicar degradação desses compostos. Salientamos, entretanto, que a oxidação lipídica é fenômeno espontâneo em óleos vegetais e que a adição de agentes antioxidante em formulações cosméticas a base de óleos muitas vezes se faz necessário para aumentar a estabilidade e proteger os componentes do óleo frente à oxidação (Savian et al, 2011).

A determinação da capacidade antioxidante em óleos encontra dificuldades na falta de padronização de um método adequado, visto que a maioria dos métodos foi desenvolvida para a análise de compostos hidrofílicos em amostras aquosas ou hidrofílicas. A fração hidrofóbica dos óleos não se mistura ao meio aquoso, comum aos ensaios de capacidade antioxidante. Consequentemente, a turbidez da amostra prejudica a determinação e os resultados gerados 
não são reprodutíveis. Embora inúmeras investigações a respeito da capacidade antioxidante de óleos vegetais estejam sendo desenvolvidas, ainda não há consenso a respeito da melhor maneira de adaptar os ensaios disponíveis, e a quantidade de informação publicada é insuficiente (Castelo-Branco e Torres, 2011). Ainda assim, Prior et al (2005) indicam o uso do TEAC como possível de ser adaptado para compostos lipofílicos.

Os óleos vegetais apresentam vantagens sobre os óleos minerais por serem menos oclusivos permitindo boa penetração na pele e capacidade de transporte de agentes terapêuticos. Ainda assim, possui ação emoliente e oclusiva que favorece a permeação e concentração de água na pele, evitando, dessa forma, a desidratação (Morais, 2006). Uma formulação O/A possui a ação tópica da fração oleosa aliada à função emoliente da fase aquosa, além de manter-se mais estável no leito da ferida.

As emulsões O/A com 30\% de óleo de Rosa Mosqueta proposta neste estudo foram estáveis por 30 dias mesmo armazenadas sob alta temperatura e umidade. Durante esse período, mostraram compatibilidade com o $\mathrm{pH}$ da pele e espalhabilidade adequada para aplicação tópica. Além disso, as emulsões mostraram maior capacidade antioxidante até o dia 60 em relação ao óleo puro, possivelmente indicando proteção da fração oleosa e de seus princípios ativos pela fase aquosa.

Os dados apresentados nesse estudo de estabilidade permitem inferir que a emulsão com óleo de Rosa Mosqueta 30\% pode ser mais eficiente no tratamento de feridas abertas do que o óleo puro. Entretanto, estudos de eficácia e segurança são necessários antes de uma recomendação clínica.

Estudos posteriores são indicados para avaliar a estabilidade da emulsão desenvolvida neste estudo em condições de armazenamento diversas, além de aprimorar a formulação pela adição de compostos antioxidantes buscando aumentar o tempo de estabilidade do produto e prolongar a ação biológica dos constituintes do óleo. 


\subsection{ESTUDO MORFOLÓGICO E MORFOMÉTRICO DO PROCESSO DE} CICATRIZAÇÃO EM RATOS WISTAR ADULTOS TRATADOS COM CREME DE ÓLEO DE ROSA MOSQUETA

\section{Método}

O estudo foi realizado no Laboratório de Cirurgia Experimental - CIEX da Faculdade de Medicina da Universidade de Brasília e aprovado pela Comissão de Ética no Uso Animal CEUA sob o protocolo UnBDoC nº 28919/2015.

\section{Aquisição dos materiais}

Óleo de Rosa Mosqueta (S100) - foi adquirido óleo puro refinado da Pharma Nostra (lote $\mathrm{n}^{\mathrm{o}}$ 37/01), obtido de matéria prima chilena por prensagem a frio de sementes de Rosa Mosqueta. O óleo, analisado por cromatografia gasosa apresenta os seguintes parâmetros e constituintes de acordo com os quadros 4 e 5 a seguir:

Quadro 4 Descrição dos parâmetros físico-químicos do óleo de Rosa Mosqueta segundo cromatografia gasosa.

\begin{tabular}{|c|c|c|c|}
\hline Testes & Especificações & Resultados & Referências \\
\hline Descrição & $\begin{array}{l}\text { Líquido amarelo a } \\
\text { alaranjado, com odor } \\
\text { característico }\end{array}$ & $\begin{array}{l}\text { Líquido amarelo a } \\
\text { alaranjado, com odor } \\
\text { característico }\end{array}$ & Fabricante \\
\hline Densidade relativa & $0,915-0,933 \mathrm{~g} / \mathrm{cm} 3$ & $0,925 \mathrm{~g} / \mathrm{cm} 3$ & Fabricante \\
\hline Índice de acidez & Máx. 1,0 mgKOH/g & $0,2 \mathrm{mgKOH} / \mathrm{g}$ & Fabricante \\
\hline Índice de Iodo & $124-182 \mathrm{cgl} / \mathrm{g}$ & $155 \mathrm{cgl} / \mathrm{g}$ & Fabricante \\
\hline Índice de peróxido & Máx. 10,0 meq/Kg & $3,1 \mathrm{meq} / \mathrm{Kg}$ & Fabricante \\
\hline Umidade & Máx. 0,3\% & Isento & Fabricante \\
\hline
\end{tabular}

Quadro 5 Composição do óleo de Rosa Mosqueta segundo análise em cromatografia gasosa*.

\begin{tabular}{|ll|}
\hline \multicolumn{1}{|c|}{ Nome } & \multicolumn{1}{c|}{ Concentração } \\
\hline Ácido Mirístico & 0,0 a $0,3 \%$ \\
\hline Ácido Palmítico & 2,0 a $10,0 \%$ \\
\hline Ácido Palmitoléico & 0,0 a $1,0 \%$ \\
\hline Ácido Oléico & 10,0 a $20,0 \%$ \\
\hline Ácido Linoléico & 35,0 a $60,0 \%$ \\
\hline Ácido Linolênico & 25,0 a $50,0 \%$ \\
\hline Ácido Araquídico & 0,0 a $2,0 \%$ \\
\hline Ácido Behênico & 0,0 a $1,0 \%$ \\
\hline
\end{tabular}

*Fonte: Informação do fabricante. 
Creme de Rosa Mosqueta 30\% (E30): o creme foi elaborado no Laboratório de Controle de Qualidade do Campus Ceilândia da Universidade de Brasília, utilizando 30\% do óleo puro em base aquosa de gel de carbômero 940 pelo método de inversão de fases. Os constituintes líquidos e oleosos do creme foram filtrados em filtro para seringa com $0,45 \mu \mathrm{M}$ e o procedimento foi realizado em capela de fluxo laminar. O creme passou por teste de estabilidade acelerada, tendo validade mínima de 30 dias, suficiente para o procedimento deste estudo.

Óleo de Rosa Mosqueta 30\% (S30) - manipulado por meio da diluição do óleo puro em óleo mineral a uma concentração de $30 \%$

Creme de óleo mineral a 30\% (OM30) - elaborado pelo mesmo método do creme de Rosa Mosqueta, substituindo-se o óleo de Rosa Mosqueta por óleo mineral a uma concentração de $30 \%$ para formação da emulsão.

Colágeno 50\% (C50) - foi elaborado pela Farmácia Escola da Universidade Federal de Goiás utilizando-se a formulação de 50\% de colágeno líquido, 10\% de alginato de cálcio e $40 \%$ de gel de carbômero.

\section{Procedimentos do Estudo}

Foram adquiridos 144 ratos da espécie Rattus norvegicus, linhagem Wistar (Abreu et al, 2011), todos machos (Marchini, 1994), do biotério central da Faculdade de Medicina da Universidade de São Paulo. Os animais foram acomodados no biotério da Faculdade de Medicina da Universidade de Brasília em gaiolas de polipropileno de dimensões $35 \mathrm{~cm} \times 50 \mathrm{~cm} \times 20 \mathrm{~cm}$ forradas de maravalha esterilizada de pinus branco (Marques, 2005; Neves, 2013), até atingirem a idade de 120 dias de vida e peso médio de 400g no início do estudo. Foi oferecido ração para roedores e água à vontade. $\mathrm{O}$ ambiente manteve temperatura controlada em torno de $22 \pm 2^{\circ} \mathrm{C}$ e umidade relativa entre $50 \%$ e $60 \%$, em fotoperíodo de $12 \mathrm{~h}$ claro e 12h escuro (Neves, 2013), com exaustor de ar empregando 10 a 15 trocas por hora (Marques, 2005). Os animais foram aleatorizados em 6 grupos segundo os tratamentos a seguir: 1) C50 - tratados com gel de colágeno a 50\% (controle positivo); 2) E30 - tratados com creme de óleo de Rosa Mosqueta a 30\%; 3) S30 - tratados com óleo de Rosa Mosqueta a 30\%; 4) S100 - tratados com óleo puro de Rosa Mosqueta; 5) OM30 - Tratados com creme de 
óleo mineral a 30\% (controle negativo); 6) SF - tratados com solução salina 0,9\% (controle negativo).

\section{Confecção da feria cutânea}

No dia do procedimento, os animais foram anestesiados com solução de $75 \mathrm{mg} / \mathrm{Kg}$ de cloridrato de cetamina e $10 \mathrm{mg} / \mathrm{Kg}$ de cloridrato de xilazina IM e posicionados em prancha de madeira em decúbito ventral com contensão dos membros de forma a expor a região dorsal do animal. Imediatamente antes do procedimento cirúrgico foi realizada tricotomia no dorso do animal de uma área $5 \mathrm{~cm} \times 5 \mathrm{~cm}$ a partir da linha de inserção das patas dianteiras prosseguindo caudalmente.

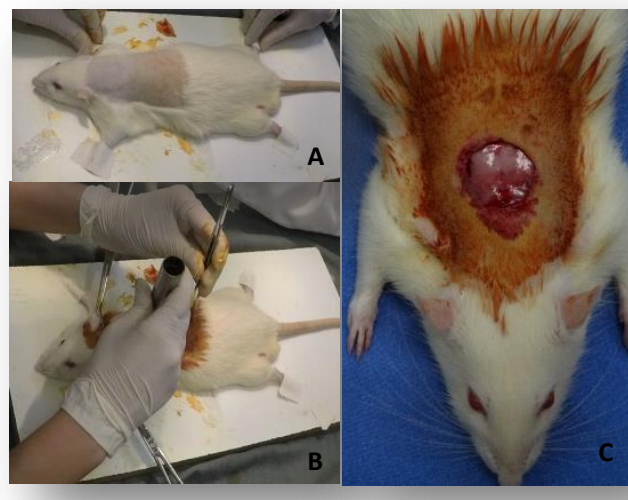

Figura 20 Procedimentos para confecção da ferida cirúrgica: A - Tricotomia da área de confecção da ferida; B - Demarcação da lesão; C- Confecção da ferida.

Antissepsia local foi realizada com álcool iodado $2 \%$. Uma área circular de $2 \mathrm{~cm}$ de diâmetro foi demarcada com punch metálico ( $c f$. Fig. 19) permitindo a confecção da ferida com o auxílio de lâmina de bisturi $n^{\circ} 11$ até exposição da fáscia muscular. A hemostasia foi realizada por compressão com gaze estéril. As lesões eram então fotografadas com câmera semiprofissional, modelo EOS Rebel T5i Canon®, resolução $18 \mathrm{M}$ pixels, posicionada a 30 cm de distância e $90^{\circ}$ em relação à lesão. Logo após, a ferida foi lavada com SF 0,9\% e aplicado o produto de teste de acordo com o grupo experimental. Foi oferecido dipirona gotas $30 \mathrm{mg} / \mathrm{Kg}$ misturado à água por $24 \mathrm{~h}$ no pós-operatório para controle da dor.

\section{Cuidados pós-operatórios}

Nova aplicação dos produtos de tratamento era realizada a cada $24 \mathrm{~h}$, seguindo o procedimento padrão: a) Preparo do leito: limpeza da ferida com soro fisiológico $0,9 \%$. b) Curativo: aplicação do produto a ser testado de acordo com o grupo experimental. Os animais não eram anestesiados durante esse procedimento e as feridas eram acompanhadas e avaliadas a cada troca de acordo com a presença de fibrina, tecido de granulação, edema, crostas e tecido necrótico e anotados em formulário próprio. 


\section{Eutanásia}

Nos dias $7^{\circ}, 14^{\circ}$ e $21^{\circ}$ de cicatrização, 8 animais (Damy et al, 2010) de cada grupo experimental foram eutanasiados em câmara de dióxido de carbono até morte dos animais por hipóxia. Imediatamente após constatação do óbito foi retirado fragmento do tecido cicatricial, peça com um centímetro de borda de tecido cutâneo íntegro até exposição da fáscia muscular. As peças foram armazenadas em solução de formol tamponado a 10\% e encaminhadas para confecção de lâmina histológica.

\section{$\underline{\text { Análise Macroscópica }}$}

A análise macroscópica foi realizada por observação ocular diária das lesões quanto ao tipo de tecido presente no leito da lesão, presença de granuloma em leito, presença de lesões periferida, taxa de retração da lesão e crescimento de pelos.

A área da ferida foi obtida pela medida do diâmetro vertical e horizontal com auxílio de régua milimetrada antes da retirada do fragmento da lesão e calculada pela equação (Falcão et al, 2001):

$$
\mathrm{A}=\pi \text { R.r }
$$

Onde $\mathrm{R}$ corresponde ao raio do maior diâmetro e $\mathrm{r}$ corresponde ao raio de menor diâmetro da ferida. A taxa de retração $\left(T_{r}\right)$ foi calculada pela equação:

Equação 8

$$
\operatorname{Tr}=\mathrm{A}_{\mathrm{f}}-\mathrm{A}_{0} .
$$

Onde $\mathrm{A}_{\mathrm{f}}$ corresponde à área final e $\mathrm{A}_{0}$ corresponde à área inicial.

A análise do leito da lesão foi feita por meio de escala Likert atribuindo-se valores de 0 a 4 para a presença de tecidos necrótico, de granulação, fibrinoso ou de reepitelização ( $c f$ Fig. 20): 

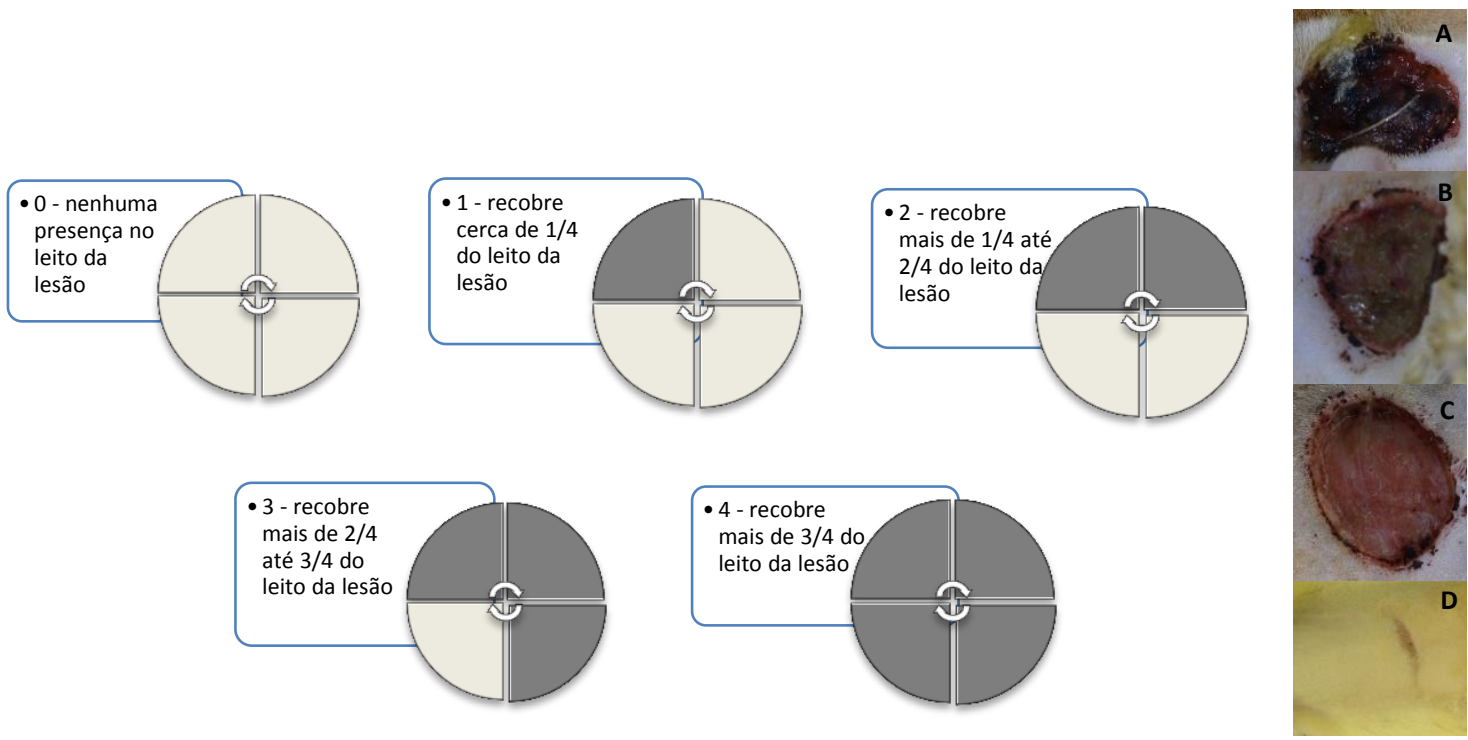

Figura 21 Esquema de avaliação morfológica do leito da lesão por tipo de tecido presente. Legenda: A Tecido necrótico; B - Tecido fibrinoso; C - Tecido de granulação; D - Tecido de epitelização.

\section{$\underline{\text { Análise Histológica }}$}

As peças histológicas foram incluídas em parafina e microtomizadas para confecção das lâminas. Cada peça foi corada em hematoxilina-eosina para análise de infiltrado inflamatório local, proliferação vascular e proliferação de fibroblastos. A avaliação da densidade e organização de fibras colágenas foi realizada utilizando-se coloração de picrosírius. A análise histológica foi realizada de forma cegada por especialista. Para todas as variáveis foi aplicada escala likert atribuindo-se valores de 0 a 3.

\section{$\underline{\text { Análise Estatística }}$}

Os dados foram analisados no programa SPSS for Windows 20.0 e os gráficos e figuras construídas no programa GraphPad Prism 7.0. A normalidade da amostra foi definida por meio do teste Shapiro-Wilk. Dados multivariados foram submetidos a teste estatístico de Kruskal-Wallis e Anova Two-Way com pós-teste de Benjamini, Krieger e Yekutieli. A análise qualitativa foi realizada utilizando-se o Teste Exato de Fisher. Diferenças entre médias foram consideradas significativas quando $\mathrm{p} \leq 0,05$.

\section{Resultados e Discussão}


Após a confecção das feridas, dois animais morreram devido ao procedimento anestésico e não foram substituídos. Outros 3 animais foram excluídos da amostra por desenvolverem pneumonia no biotério dois dias após a confecção da ferida. Esses animais foram eutanasiados e encaminhados à análise anátomo patológica.

\section{Avaliação Morfométrica}

Os animais do grupo C50 apresentaram sangramento após a confecção das feridas com formação de crosta no leito da lesão, enquanto as lesões dos grupos E30, S30 e S100 mostraram melhor hemostasia. A maioria dos animais desenvolveu crosta amarelada no leito da lesão que evoluiu para necrose especialmente nos grupos C50 e OM30. Não foram observados edema local ou secreção. A figura 21 abaixo mostra a evolução das lesões por grupo de tratamento nos dias 7, 14 e 21 de cicatrização até completa reepitelização. É possível notar a formação de crosta escura no leito da lesão até o $7^{\circ}$ dia. Aos 14 dias a epitelização está quase completa, finalizada no $21^{\circ}$ dia.

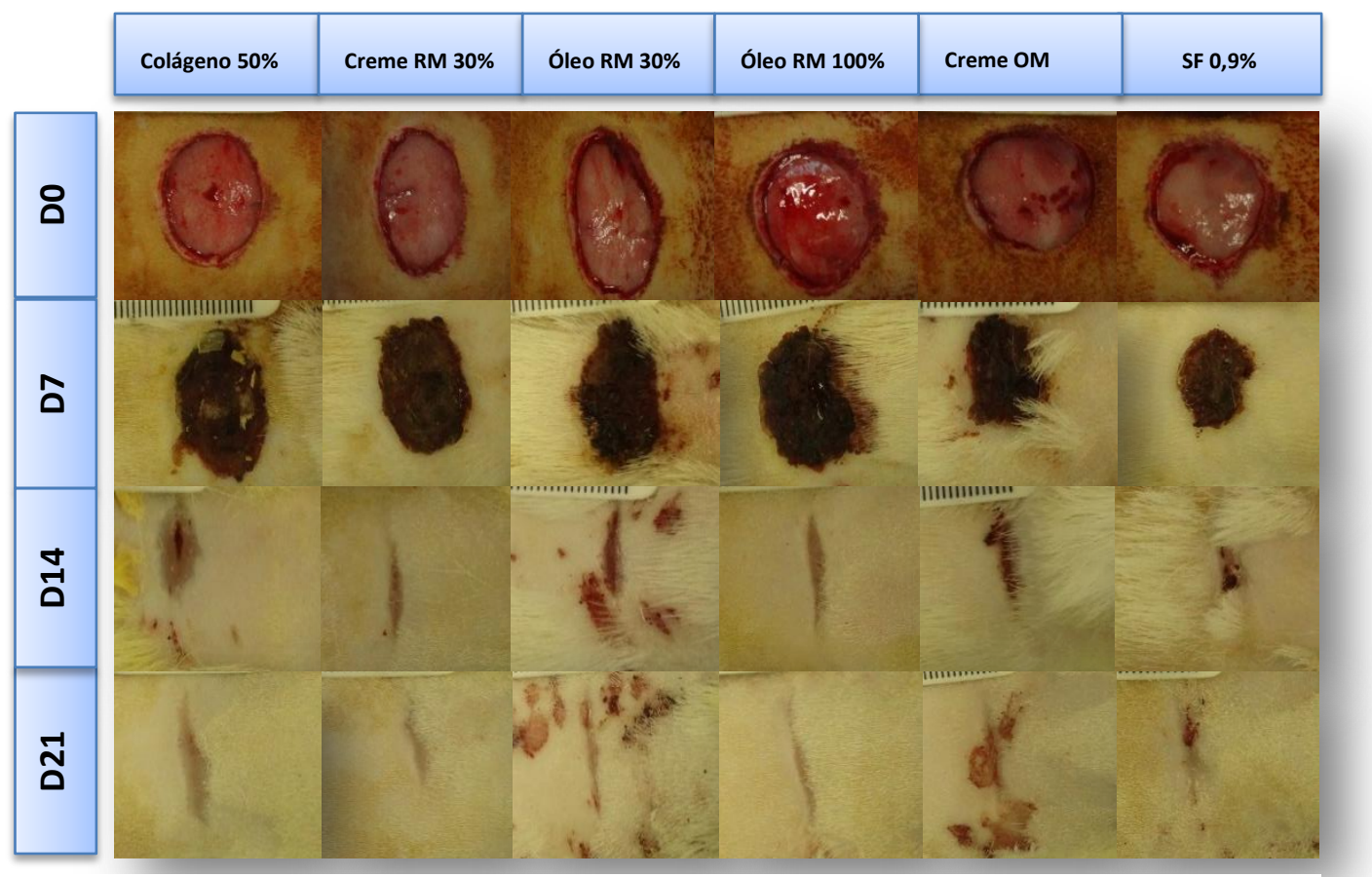

Figura 22 Evolução do processo de cicatrização por grupo de tratamento e tempo de eutanásia. Brasília, 2016. 
O grupo C50 apresentou menores índices de tecido fibrinoso que os demais grupos até o $3^{\circ}$ dia de tratamento. Os animais do grupo E30 mostraram menor formação de tecido fibrinoso comparado aos animais dos grupos OM30 $(\mathrm{p}=0,002)$ e $\mathrm{S} 30(\mathrm{p}=0,007)$ a partir do $3^{\circ}$ dia. A solução S100 mostrou-se mais eficaz na prevenção de formação de tecido fibrinoso no leito da lesão quando comparada aos cremes E30 (p=0,02) e OM30 (p<0,001). O óleo de Rosa Mosqueta 30\% apresentou menor formação de tecido fibrinoso comparado ao grupo OM30 $(\mathrm{p}=0,03)$ no sexto dia de cicatrização.

A formação de tecido necrótico no leito da lesão foi maior no grupo C50 comparado aos demais grupos, exceto o grupo SF. Já o grupo E30 foi avaliado com menor necrose tecidual entre o $5^{\circ}$ e o $11^{\circ}$ dia de cicatrização quando comparado aos grupos C50 (p<0,001), $\mathrm{S} 30(\mathrm{p}=0,002)$, OM30 ( $\mathrm{p}=0,002)$ e SF (p=0,003). A solução oleosa S100 foi capaz de reduzir a formação de necrose tecidual quando comparado aos grupos C50 (p<0,001), OM30 $(p<0,001)$ e SF $(p=0,004)$. Mesmo a solução S30 foi mais eficiente na prevenção de tecido necrótico quando comparado a C50 (p=0,008), OM30 (p=0,001) e SF (p=0,003).

Quanto à formação do tecido de granulação, houve maiores índices no grupo S100 nos primeiros dias de cicatrização quando comparado aos grupos E30 (p=0,01), OM30 (p=0,01) e $\mathrm{SF}(\mathrm{p}=0,03)$. A partir da segunda semana de cicatrização, o grupo E30 mostrou-se superior ao grupo $\mathrm{S} 30$ ( $\mathrm{p}=0,006)$, OM30 ( $\mathrm{p}=0,03)$ e $\mathrm{SF}(\mathrm{p}=0,03)$ na visualização de tecido de granulação.

A partir da segunda semana de tratamento, foi possível observar formação de tecido de epitelização no grupo C50 comparado aos grupos E30 (p<0,001), S30 (p=0,01), OM30 $(p<0,001)$ e SF ( $p=0,004)$. Não houve diferença estatística entre os grupos C50 e S100 quanto à formação de tecido epitelial. Entretanto, o grupo S100 mostrou-se superior aos grupos E30 $(\mathrm{p}=0,01)$ e OM30 $(\mathrm{p}<0,001)$ a partir do $12^{\circ}$ dia de tratamento. Já o grupo tratado E30 apresentou menor formação de tecido epitelial quando comparado aos demais grupos no $15^{\circ}$ dia. Após o $17^{\circ}$ dia de tratamento não houve diferenças estatísticas entre os grupos quanto à formação de tecido epitelial.

A avaliação morfométrica das lesões é descrita na figura 22 que mostra a formação dos tecidos observados visualmente ao longo dos dias de cicatrização por grupo de tratamento. 
2
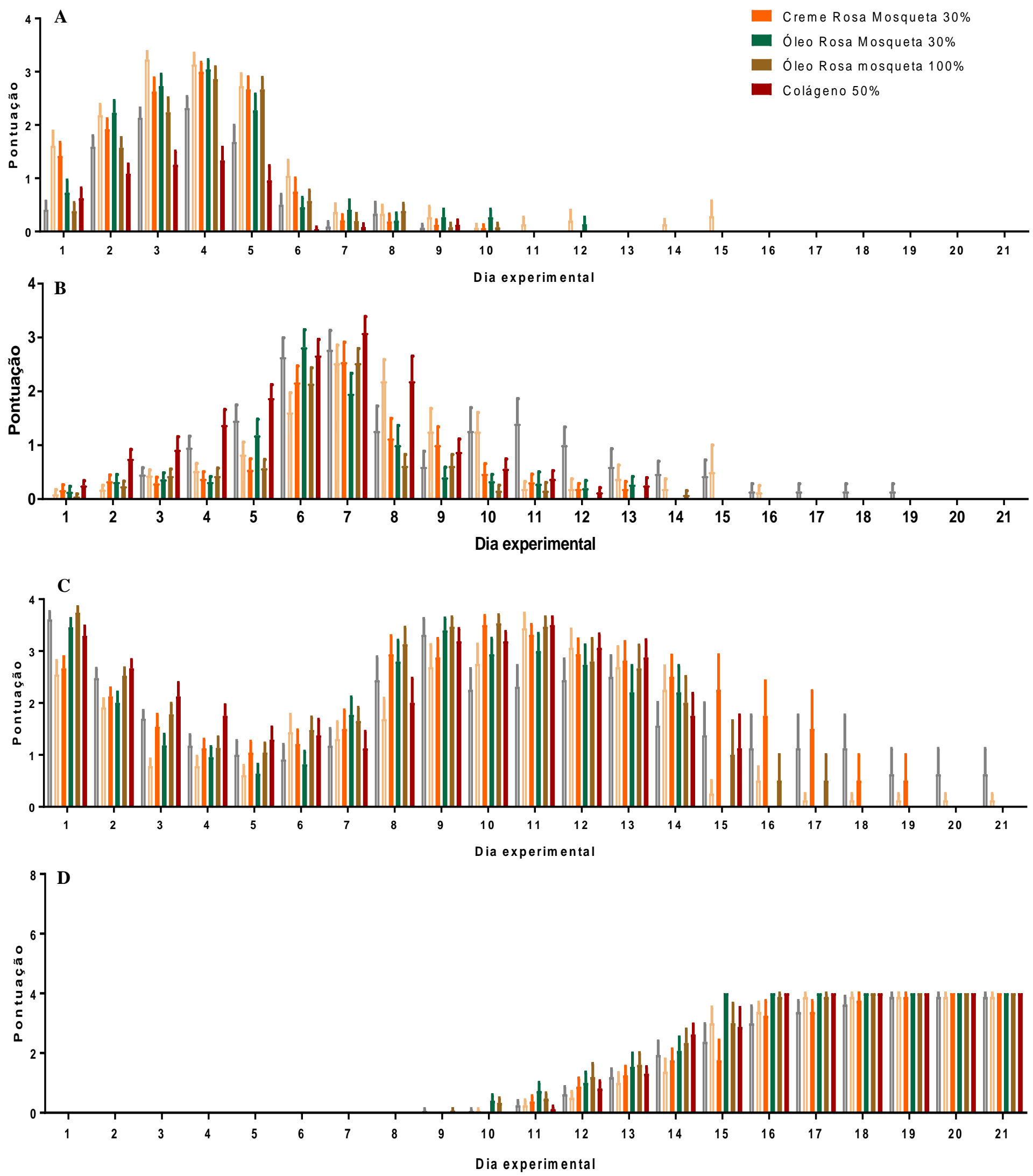

Figura 23 Evolução das lesões durante o processo de cicatrização por tipo de tecido observado em leito de acordo com o grupo de tratamento. Brasília, 2016. Legenda: A - Tecido fibrinoso; B - Tecido necrótico; C - Tecido de granulação; D - Tecido de epitelização. Teste Anova Two-Way com pós-teste de Benjamini, Krieger e Yekutieli, p $\leq 0,05$. 
A presença de lesões periferida ao longo dos dias de avaliação foi mais prevalente nos grupos tratados com creme de óleo mineral $30 \%$ e óleo de Rosa Mosqueta 30\% (cf. Fig.23).

Não houve diferença estatisticamente significativa no tempo de cicatrização entre os grupos, embora o grupo S100 tenha apresentado tempo de

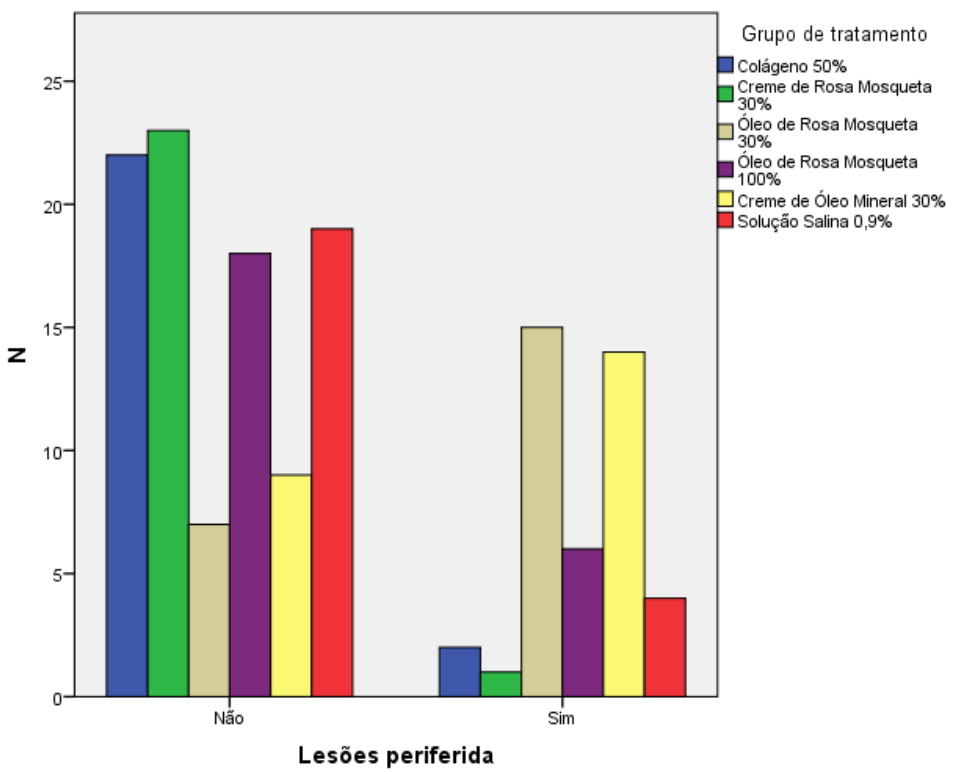
cicatrização menor aos demais Figura 24 Proporção de ocorrência de lesões periferida entre os grupos (cf. Fig. 24). A taxa de grupos de tratamento ao longo do tempo de cicatrização. Brasília, retração da lesão foi maior nos grupos E30 e S100 nos primeiros 7 dias ( $c f$. Fig. 25), mas não foi identificada diferença estatística significativa entre os grupos $(\mathrm{p}=0,686)$.

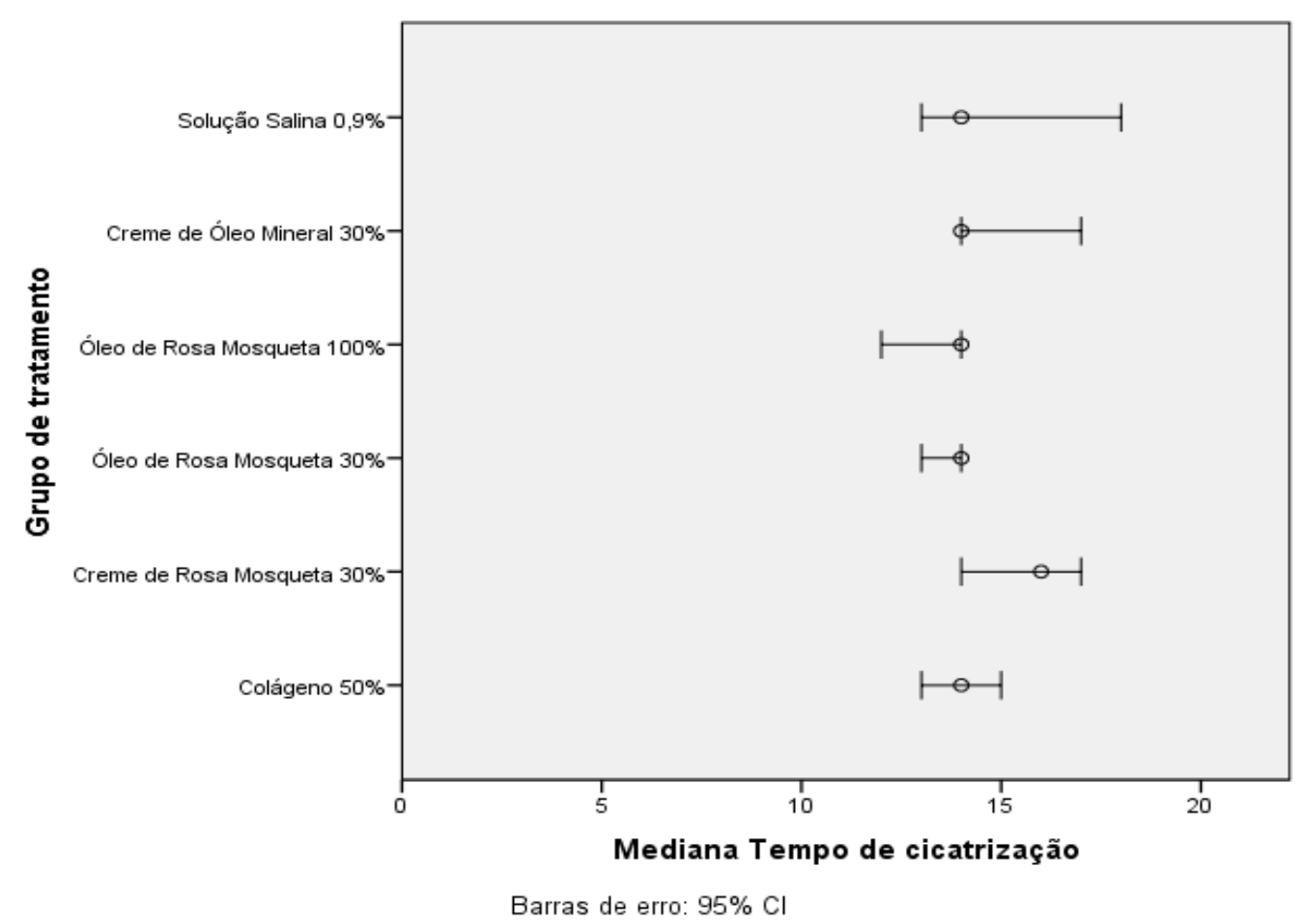

Figura 25 Mediana de tempo de cicatrização por grupo de tratamento. Brasília, 2016. Teste Kruskal-Wallis, $\mathrm{p}=0,134$. 


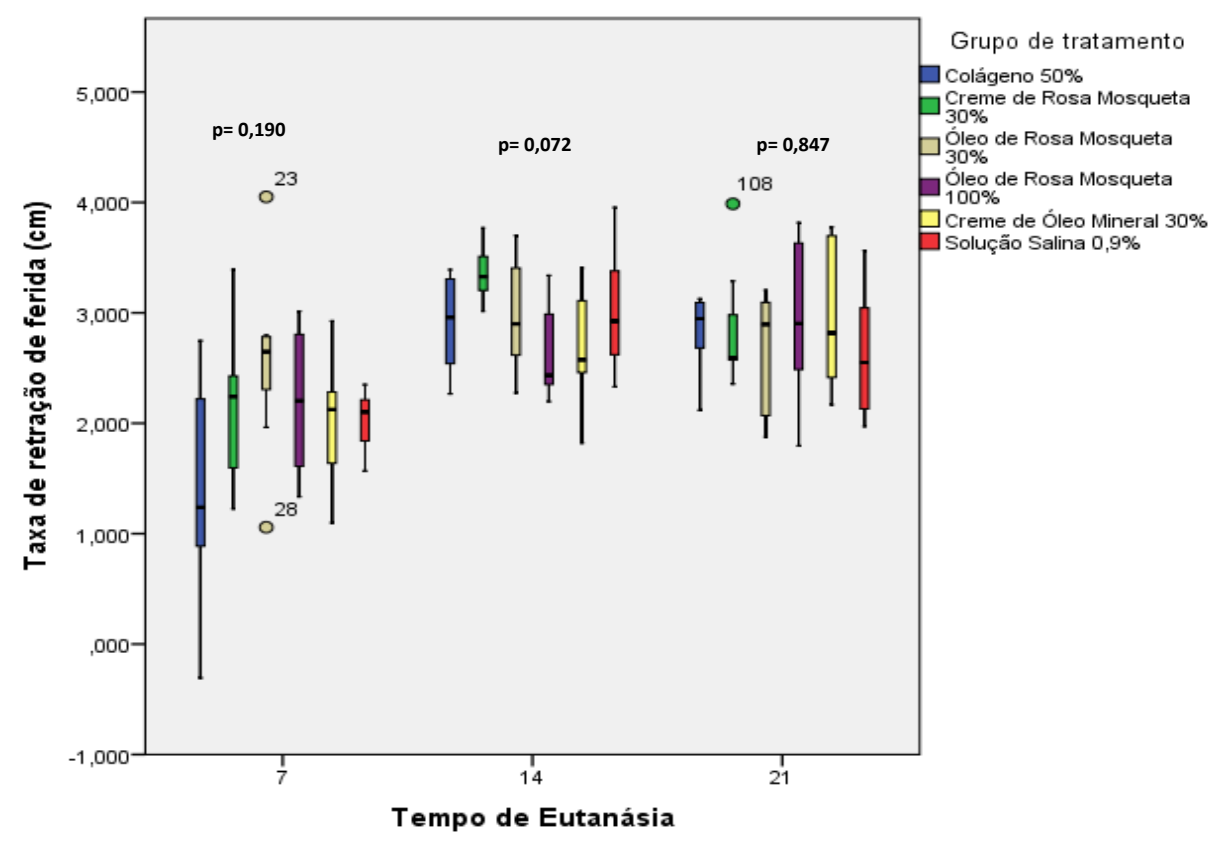

Figura 26 Taxa de retração das lesões por grupo de tratamento nos dias 7, 14 e 21 de cicatrização. Brasília, 2016. Teste de Kruskal Wallis, p=0,190.

\section{Análise Morfológica}

A análise morfológica das lesões avaliou presença de fibroblastos e deposição de colágeno no leito da ferida, infiltrado inflamatório e vasos neoformados variando de ausente a intensa. A análise estatística mostrou diferença significativa entre os grupos tratados para deposição de colágeno e presença de monócitos e polimorfonucleados no leito da lesão.

Houve deposição intensa de colágeno no grupo SF (controle negativo) no $14^{\circ}$ dia de cicatrização, não havendo diferença entre os grupos no dia 21. O grupo E30 e C50 apresentaram menor infiltrado inflamatório durante todo o processo de cicatrização e o grupo OM30 estimulou a formação de neovasos no dia 14. A figura 26 resume as características histológicas das lesões nos tempos de cicatrização 7, 14 e 21 por grupo de tratamento. 

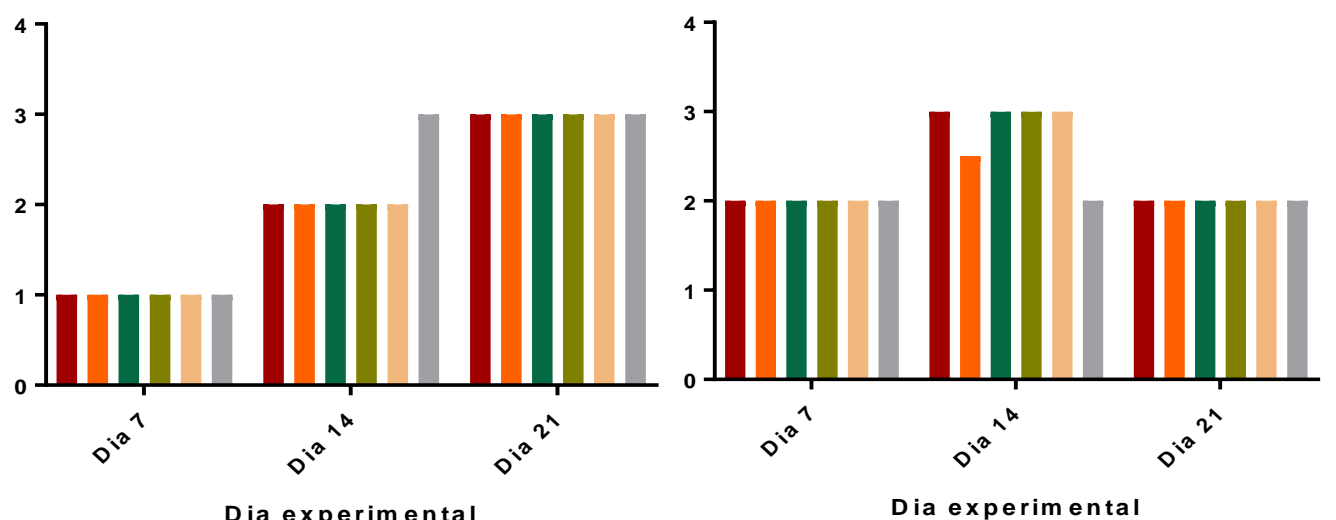

Colágeno $50 \%$

Creme Rosa Mosqueta $30 \%$

- Óleo Rosa Mosqueta 30\%

- Óleo Rosa Mosqueta $100 \%$

- Creme de Óleo mineral 30\%

Solução salina $0.9 \%$

Presença de Polimorfonucleados

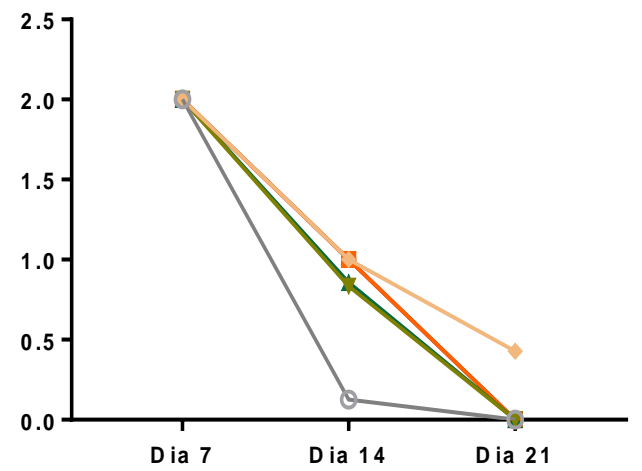

Dia experimental

Hem orragia

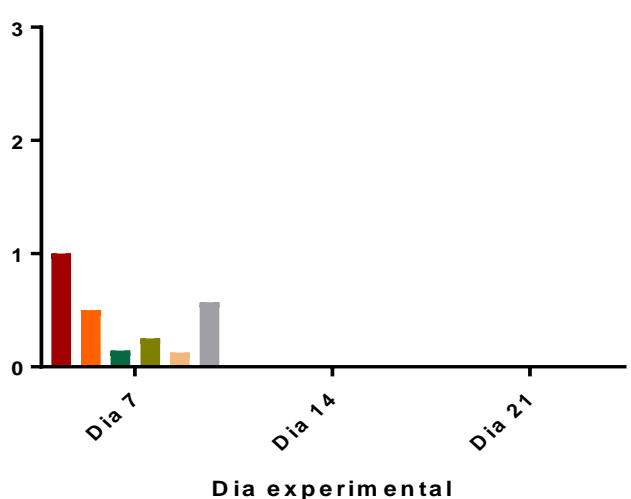

Dia experimental

Presença de Monócitos

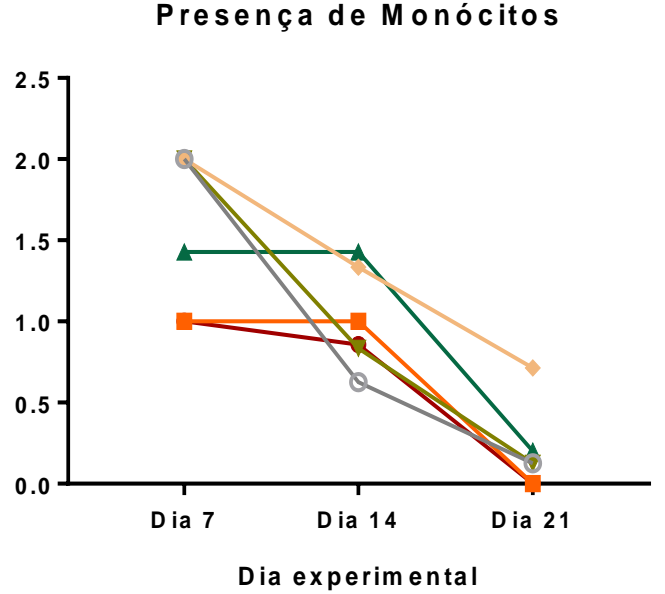

Vasos Neoformados

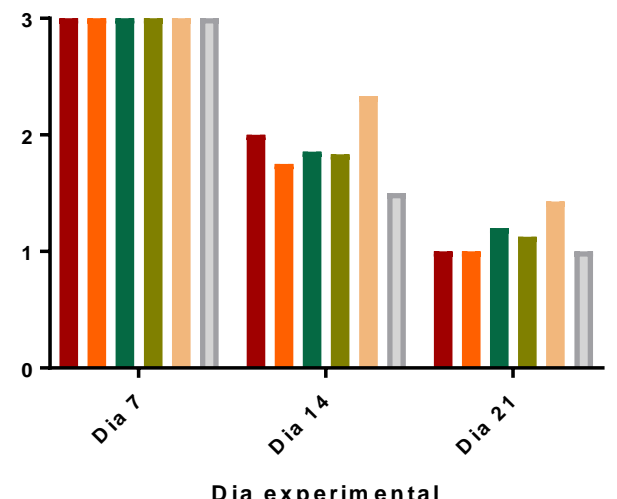

Colágeno $50 \%$

-Creme Rosa Mosqueta $30 \%$

$\leftarrow$ Óleo Rosa Mosqueta $30 \%$

$\rightarrow$ Óleo Rosa Mosqueta $100 \%$

$\rightarrow \quad$ Creme de Óleo mineral $30 \%$

- - Solução salina $0.9 \%$

Figura 27 Características histológicas da lesões por grupo de tratamento nos dias experimentais 7, 14 e 21, Brasília, 2016. Teste Anova Two-Way com pós-teste de Benjamini, Krieger e Yekutieli, $\mathrm{p} \leq 0,05$.

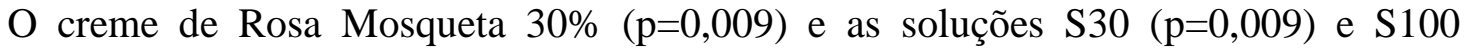
$(\mathrm{p}=0,03)$ foram superiores ao creme de óleo mineral 30\% para estimular a deposição de 
colágeno no leito da ferida no dia 14. Entretanto, o grupo controle negativo (SF) apresentou maior deposição de colágeno que o grupo controle positivo (C50) $(\mathrm{p}<0,001)$ e o grupo OM30 $(\mathrm{p}<0,001)$. No dia 21 de cicatrização não houve diferença estatística na quantidade de colágeno no leito da ferida entre os grupos comparados.

O grupo SF apresentou menor quantidade de polimorfonucleados $(\mathrm{p}<0,001)$ no $14^{\circ}$ dia de tratamento em relação aos demais grupos, não havendo diferença estatística na quantidade de polimorfonucleados no $21^{\circ}$ dia de cicatrização.

No dia 7 de tratamento, foi observado menor infiltrado de monócitos nos grupos C50 e E30. Já no $14^{\circ}$ e $21^{\circ}$ dias de cicatrização os grupos E30 e S100 foram mais eficientes que os grupos $\mathrm{S} 30(\mathrm{p}=0,01)$ e OM30 ( $\mathrm{p}=0,05)$ na redução do infiltrado inflamatório. Aos 21 dias de cicatrização foi observado menor infiltrado inflamatório nos grupos C50, E30, S30 e SF.

Quanto à formação de neovasos, não houve diferença estatística significativa entre os grupos tratados até o $14^{\circ}$ dia de cicatrização quando o grupo OM30 mostrou-se mais eficaz na estimulação para formação de novos vasos. Os grupos S30, S100 e OM30 foram mais eficazes no controle de hemorragia até o $7^{\circ}$ dia de cicatrização.

A tabela 6 mostra os valores de cada item avaliado correspondentes ao grupo de tratamento com o respectivo $\mathrm{p}$ valor.

Tabela 5 Mediana dos valores referentes aos itens avaliados por grupo de tratamento e respectivo p valor. Brasília, 2016.

\begin{tabular}{lllllllll}
\hline & Dia & E50 & E30 & S30 & S100 & OM30 & SF & $\begin{array}{c}\text { p } \\
\text { Valor }\end{array}$ \\
\hline \multirow{3}{*}{ Colágeno } & 07 & 1 & 1 & 1 & 1 & 1 & 1 & $<0,05$ \\
& 14 & $2^{*}$ & $2,25^{*}$ & $2,28^{*}$ & $2,16^{*}$ & $1,67^{* \&}$ & $2,62^{\$}$ & \\
Fibroblastos & 21 & 3 & 3 & 3 & 2,87 & 2,57 & 2,87 & \\
\multirow{4}{*}{ Polimorfonucleados } & 07 & 2 & 2 & 2 & 2 & 2 & 2 & \\
& 14 & 2,71 & 2,5 & 2,71 & 2,83 & 2,71 & 2,37 & 0,118 \\
Monócitos & 21 & 2 & 2 & 2 & 2,37 & 2,42 & 2,12 & \\
& 07 & 2 & 2 & 2 & 2 & 2 & 2 & \\
Neovasos & 14 & $1^{*}$ & $1^{*}$ & $0,85^{*}$ & $0,83^{*}$ & $1^{*}$ & $0,125^{\&}$ & 0,005 \\
& 21 & 0 & 0 & 0 & 0 & 0,428 & 0 & \\
Hemorragia & 07 & $1^{*}$ & $1^{*}$ & $1,42^{\$}$ & $2^{\&}$ & $2^{\&}$ & $2^{\&}$ & \\
& 14 & $0,85^{* *}$ & $1^{*}$ & $1,42^{\$}$ & $0,83^{*}$ & $1,33^{\&}$ & $0,62^{\#}$ & $<0,001$ \\
& 21 & $0^{*}$ & $0^{*}$ & $0,2^{*}$ & $0,125^{\&}$ & $0,714^{\$}$ & $0,125^{*}$ & \\
& 07 & 3 & 3 & 3 & 3 & 3 & 3 & \\
& 14 & $2^{*}$ & $1,7^{* \&}$ & $1,8^{* \&}$ & $1,83^{* \&}$ & $2,33^{\$}$ & $1,5^{\&}$ & 0,005 \\
& 21 & 1 & 1 & 1,2 & 1,12 & 1,42 & 1 & \\
& 07 & $1^{*}$ & $0,5^{* \&}$ & $0,14^{\&}$ & $0,25^{\&}$ & $0,125^{\&}$ & $0,57^{* \&}$ & \\
& 14 & 0 & 0 & 0 & 0 & 0 & 0 & $<0,001$ \\
\hline
\end{tabular}

*Letras diferentes correspondem a diferenças estatísticas. Anova Two-Way com pós-teste de Benjamini, Krieger e Yekutieli. 
A avaliação qualitativa mostrou maior ocorrência de microabscessos no grupo C50 até o $7^{\circ}$ dia de cicatrização. A reepitelização foi mais evidente nos grupos S100 e SF no dia 14. O grupo tratado com creme de óleo mineral apresentou maior frequência de úlcera e de crosta a partir do dia 14 ( $c f$ Fig. 27). Todas as lesões no grupo controle negativo (SF) apresentaram aspecto deprimido nos dias 14 e 21 enquanto o grupo E30 apresentou cicatriz mais elevada ( $c f$ Fig. 28).

Reepitelização

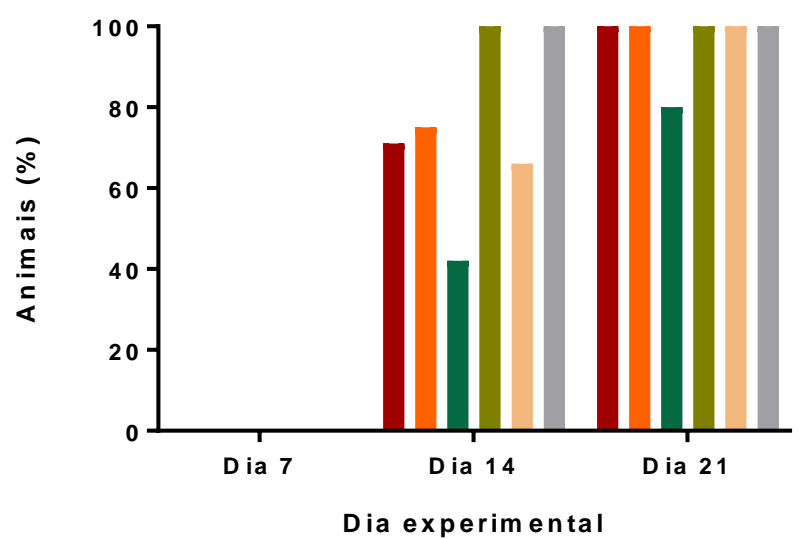

Presença de Crosta

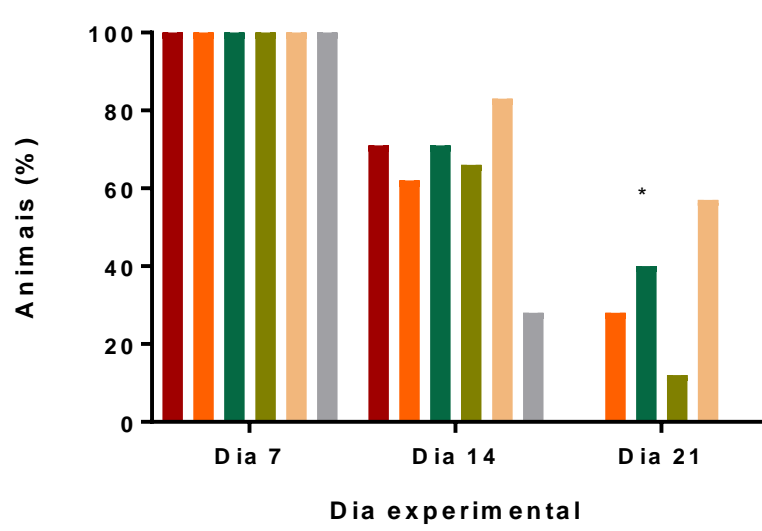

Colônias

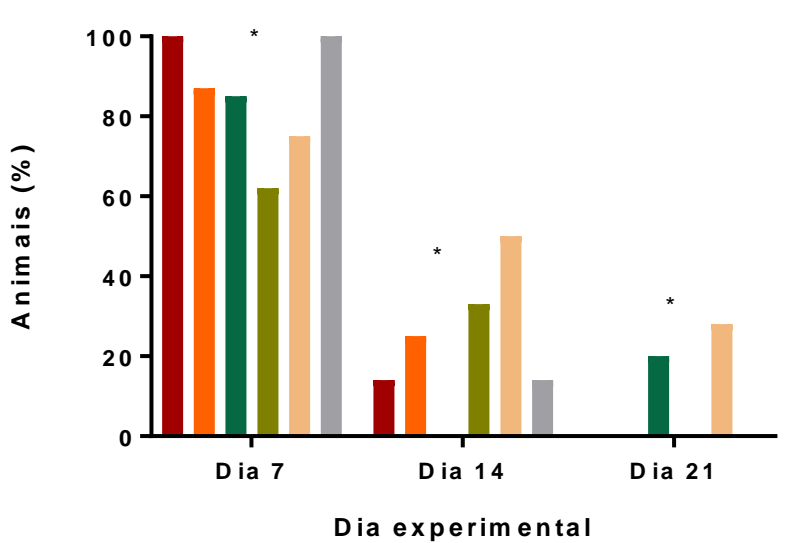

Colágeno $50 \%$

- Creme Rosa Mosqueta $30 \%$

- Óleo Rosa Mosqueta $30 \%$

Óleo Rosa Mosqueta $100 \%$

Creme de Óleo mineral $30 \%$

- Solução salina $0.9 \%$

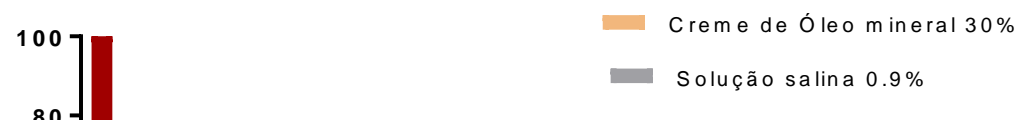

Dia experimental

Presença de Úlcera

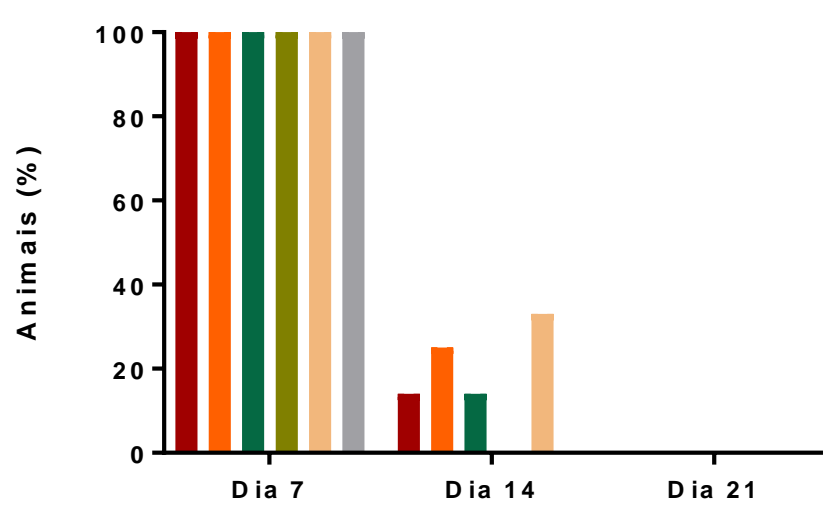

Dia experimental

Corpo Estranho

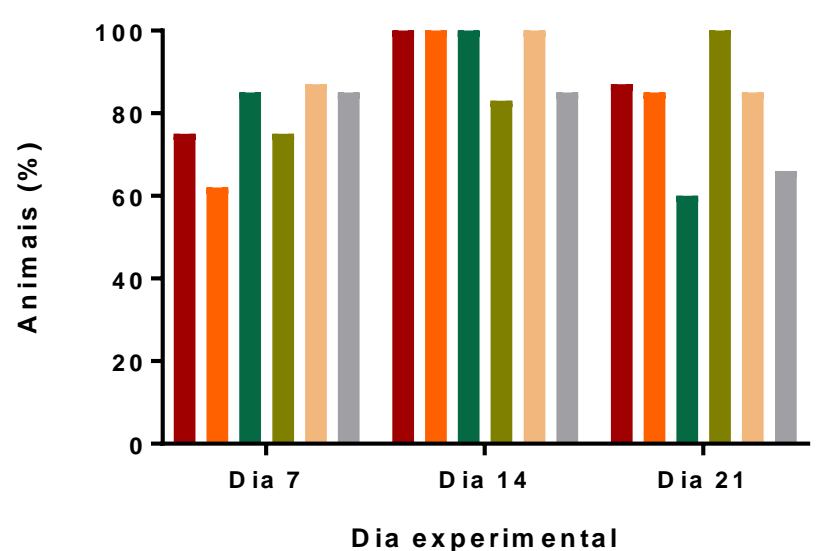

Figura 28 Avaliação histológica qualitativa das lesões quanto à presença de epitelização total, microabscesso, crosta, úlcera, colônias e corpo estranho. Teste Exato de Fisher, *p<0,001. Brasília, 2016. 

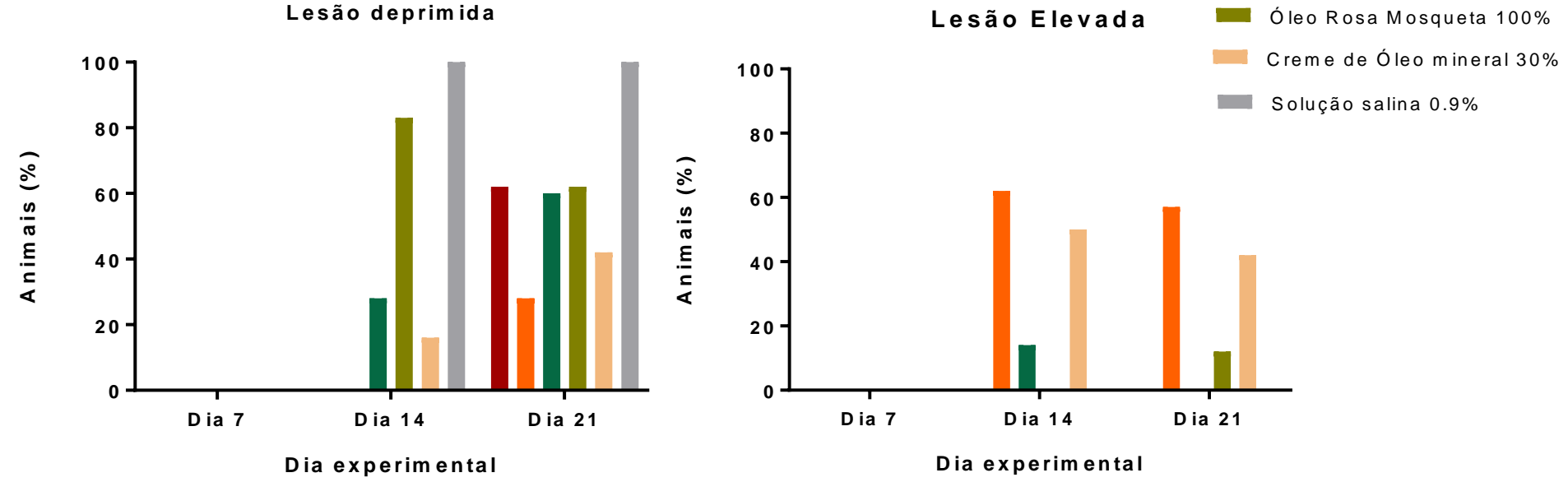

Figura 29 Avaliação estética das lesões por tipo de tratamento. Brasília, 2016.

A utilização de modelos animais para a investigação de processos patológicos espontâneos ou induzidos acompanha os estudos de causa, mecanismo e terapêutica de doenças humanas há mais de 150 anos (Fagundes \& Taha, 2004). No desenvolvimento de estudos com modelos animais, a escolha da espécie animal adequada para aquilo que se quer investigar é de extrema importância para uma posterior extrapolação dos resultados para a espécie humana (Damy et al,2010). A espécie Rattus norvegicus, linhagem Wistar tem sido indicada como o modelo animal adequado em investigações sobre o processo de cicatrização (Schanaider e Silva, 2004) pela sua proximidade com a fisiologia da pele humana, além do baixo-custo, facilidade de aquisição e ciclo de vida curto. A amostra neste estudo foi constituída por animais machos adultos a fim de se evitar a interferência de alterações hormonais.

O óleo de Rosa Mosqueta tem despertado o interesse científico por sua combinação de ácidos oleico, linoleico, linolênico e araquidônico. Estudos posteriores verificaram que feridas confeccionadas em ratos tratadas com o óleo de Rosa Mosqueta evoluíram com maior deposição de colágeno, tecido de granulação mais organizado e maior número de fibroblastos que o grupo controle (Marchini, 1994). Eurides et al (2011) também verificaram epitelização mais acelerada e cicatrização completa mais recente em animais tratados com o óleo puro de Rosa Mosqueta.

Este estudo não encontrou diferenças significativas na taxa de retração de feridas ou no tempo de cicatrização entre os grupos avaliados, embora o óleo de Rosa Mosqueta tenha mostrado cicatrização mais precoce em relação aos demais grupos. 
A avaliação histológica não mostrou atuação do óleo de Rosa Mosqueta na proliferação de fibroblastos e na redução do recrutamento de neutrófilos durante o processo de cicatrização. Tanto o creme a 30\% quanto o óleo puro de Rosa Mosqueta mostraram-se eficientes em reduzir o número de monócitos no leito da lesão ao longo dos dias de tratamento.

O maior influxo de polimorfonucleados no $14^{\circ}$ dia de tratamento em comparação do grupo controle negativo pode ser explicado pela presença dos ácidos oleico e linoleico, constituintes do óleo de Rosa Mosqueta. Avaliando o papel desses compostos na cicatrização de feridas em ratos, Pereira et al (2008) verificaram um efeito pró-inflamatório, estimulando o influxo de neutrófilos para a área da lesão. Os neutrófilo desenvolvem papel fundamental na fase inflamatória, sintetizando e liberando citoquinas, quimiocinas e fatores de crescimento, além de desbridar tecido desvitalizado (Pereira et al, 2008).

Rodrigues et al (2012) avaliaram a evolução de lesões cutâneas em ratos com ingesta de ácido oleico e linolênico, comparando os resultados com o grupo controle. A ingesta de ácidos graxos essenciais acelerou a fase inflamatória nas lesões, promovendo maior influxo de neutrófilos, produção de oxido nítrico e ativação de fatores de transcrição nas primeiras $24 \mathrm{~h}$, seguida de inibição desses fatores com a resolução do processo inflamatório. Os autores verificaram que o ácido oleico induz a ativação dos fatores de transcrição, enquanto o ácido linoleico estimula a produção de óxido nítrico, que estaria relacionado ao influxo celular com pico nas primeiras $24 \mathrm{~h}$. A rápida ativação da fase inflamatória acelera, por conseguinte, o início da fase proliferativa e formação do tecido de granulação.

A evolução da cicatrização depende da migração de células de defesa para o tecido lesionado, as quais irão iniciar o processo de limpeza local além de estimular a liberação de fatores de crescimento para proliferação e migração de fibroblastos (Williamson \& Harding, 2004). Quando o processo inflamatório não ocorre adequadamente, não há formação do tecido de granulação. Por outro lado, se o processo inflamatório se estender além do tempo ou for mais intenso do que o necessário, a liberação de endotoxinas poderá estender a lesão tecidual e o processo cicatricial ficará estagnado.

Os grupos E30, S30 e S100 mostraram maior influxo de neutrófilos até o $14^{\circ}$ dia de cicatrização quando comparado ao controle negativo. Isso pode estar relacionado ao melhor aspecto da ferida observado no estudo morfométrico, com menor formação de tecido fibrinoso e necrose no leito da lesão. Em adição, menor quantidade de monócitos foi observada nos grupos tratados com a Rosa Mosqueta, tanto com o óleo quanto com o creme, indicando 
manutenção do equilíbrio do influxo de células inflamatórias ao longo do processo cicatricial, o que pode favorecer a organização do tecido de granulação.

Os monócitos são células essenciais para a limpeza tecidual ao final da fase inflamatória e assumem importante papel na liberação de fatores de crescimento e quimioatrativos para a formação do tecido de granulação. A presença local dessas células intensifica a migração e ativação de fibroblastos e células epiteliais (Beldon, 2010). Entretanto, um influxo aumentado de células inflamatórias pode prolongar ou inviabilizar o processo cicatricial.

Os fibroblastos são os responsáveis pela síntese de colágeno no leito da lesão. O colágeno é a proteína mais abundante do tecido conectivo em fase de cicatrização, ocorrendo principalmente na forma de colágeno III na fase primária do processo cicatricial que vai sendo substituído gradualmente por colágeno tipo I, mais organizado e resistente à tração (Campos, 2007). A deposição de colágeno no leito da lesão se inicia com mais intensidade na fase proliferativa do processo de cicatrização, quando a proliferação e diferenciação de fibroblastos é estimulada por fatores de crescimento liberados pelos monócitos (Balbino, 2005). A adequada deposição de colágeno no leito da ferida irá depender do equilíbrio do processo inflamatório.

O movimento de preenchimento e fechamento da lesão depende do equilíbrio entre síntese de colágeno, formação do tecido de granulação e epitelização. Se a migração de células epiteliais for mais intensa que a formação do tecido de granulação e a síntese de colágeno, ocorrerá o fechamento da lesão sem o adequado preenchimento desta, mostrando uma cicatriz deprimida com um tecido conjuntivo incompetente. Por outro lado, se houver atraso na epitelização, o tecido de granulação irá crescer acima no nível da pele, formando uma cicatriz elevada. E se ocorre deposição intensa de colágeno, a cicatriz final irá originar um tecido fibroso menos resistente à tração (Irion, 2012).

Neste estudo, o grupo controle apresentou deposição de colágeno mais intensa no $14^{\circ}$ dia comparado aos demais grupos de tratamento, provavelmente devido ao menor influxo de células inflamatórias. Os grupos tratados com a Rosa Mosqueta, seja por meio da solução oleosa a 30\% ou pura, ou da emulsão E30 mostraram deposição moderada de colágeno acima do observado no controle negativo OM30 e comparável ao controle positivo C50.

Apesar de o grupo tratado com a Rosa Mosqueta ter apresentado menor deposição de colágeno que o controle negativo, não houve diferença na proliferação de fibroblastos entre os grupos, podendo indicar uma via de modulação na síntese ou degradação de colágeno. 
Yoon et al (2011) verificaram que o ácido araquidônico, em concentrações de até $0,025 \%$ pode estimular processo inflamatório na pele, resultando em degradação do procolágeno e menor síntese de colágeno tipo I. Autores relatam a presença de concentrações entre 0,1 e 0,01\% desse ácido graxo essencial no óleo de Rosa Mosqueta.

$\mathrm{O}$ aspecto das cicatrizes no grupo E30 mostrou maior tendência à elevação, enquanto o grupo SF apresentou cicatrizes deprimidas em todas as lesões observadas. Cicatrizes mais elevadas frequentemente são indicativos de hipergranulação, enquanto cicatrizes deprimidas indicam intensa síntese de colágeno e descompasso entre granulação e epitelização. Deve-se observar, entretanto, que o modelamento da lesão ocorre ao longo de vários meses após a completa epitelização, gerando mudanças no aspecto da cicatriz.

Os dados observados mostraram maior epitelização nos grupos C50, E30, S100 e SF comparado aos grupos S30 e OM30 aos 14 dias de tratamento, não havendo diferença entre os grupos no $21^{\circ}$ dia de avaliação. Esse dado é contrário ao encontrado por Turk et al (2013), cujo estudo da cicatrização em ratos indicou que o ácido alfa-linolênico atrasa o processo de cicatrização pela inibição dos receptores do fator de crescimento epidérmico (EGFR). É preciso destacar, entretanto, que a atividade de produtos fitoterápicos está relacionada à interação dos compostos ativos encontrados na matéria prima, que agem de forma sinérgica e apresentam ação diversificada quando isolados (Castelo-Branco \& Torres, 2011).

A ocorrência de lesões periferida foi duas vezes mais frequente no grupo OM30 do que no grupo E30 ( $\mathrm{p}=0,014 ; \mathrm{IC}=1,1-3,5$ ). Já o grupo $\mathrm{S} 100$ não apresentou diferenças na ocorrência de lesão quando comparado a seu controle negativo, a solução salina $0,9 \%$ ( $\mathrm{p}=1$; $\mathrm{RR}=0,9 ; \mathrm{IC}=0,7-1,0)$ ou ao grupo $\mathrm{E} 30(\mathrm{p}=1 ; \mathrm{RR}=1,0 ; \mathrm{IC}=0,9-1,2)$.

Os grupos S30 e RM30 apresentaram aumento significativo na ocorrência de lesões periferidas quando comparados aos grupos tratados com solução salina $0,9 \%$, creme de RM $30 \%$ ou óleo de RM 100\%. No entanto, quando comparados entre si, não houve diferenças estatísticas na ocorrência de lesões, fazendo-nos acreditar que foram resultado de reação ao óleo mineral contido nessas formulações.

Óleos minerais apresentam característica mais oclusiva que óleos vegetais, podendo provocar desconforto e irritação local. Por outro lado, essa ação oclusiva pode ter resultado na acentuada neovascularização observada no grupo OM30 no dia 14. A ação oclusiva reduz a tensão de oxigênio no leito da ferida, o que estimula a proliferação de células angiogênicas (Irion, 2012).

Os dados apresentados neste trabalho mostram que o óleo de Rosa Mosqueta em emulsão a $30 \%$ foi tão eficaz quanto o óleo puro no recrutamento de neutrófilos na fase 
inflamatória da cicatrização além de modular a resposta inflamatória na fase mais tardia. Esse dado pode ser de interesse clínico para o tratamento de feridas de difícil manejo, promovendo a liberação de fatores de crescimento, especialmente em feridas onde há necessidade de estímulo ao influxo celular e modulação do processo inflamatório. A emulsão E30 foi tão eficiente quanto o controle positivo para estimular a deposição de colágeno e proliferação de fibroblasto no leito da lesão. Entretanto, a relação entre processo inflamatório e síntese de colágeno nas lesões tratadas com Rosa Mosqueta precisa ser melhor elucidada.

À análise visual, o creme a 30\% e o óleo puro de Rosa Mosqueta mostraram lesões de melhor aspecto, prevenindo a formação de tecido fibrinoso e necrótico no leito das lesões. Embora sujeita a viés de avaliação, a análise visual e qualitativa de feridas é uma orientação da Wounds International (2015) e é indicada como estratégia de acompanhamento da evolução de feridas.

Limitações deste estudo devem ser consideradas antes de extrapolar os resultados encontrados para a prática clínica: a fisiologia da cicatrização em ratos, embora indicados como modelo experimental adequado para estudo de reparação tecidual, difere da cicatrização em humanos. Por esse motivo, a ação da Rosa Mosqueta sobre as células inflamatórias da pele deve ser mais bem esclarecida e estudos de imunoistoquímica podem ajudar a elucidar melhor essa ação.

As lesões tratadas neste estudo foram deixadas abertas pela impossibilidade de manter um curativo oclusivo nos animais, o que pode resultar em viés. Em curativos oclusivos, é possível manter a umidade adequada no leito da lesão, concentrando a ação do produto farmacêutico utilizado. Além disso, o colágeno em contato com o ambiente sofre ressecamento, o que pode ter aumentado a formação de tecido necrótico superficial nesse grupo.

Este estudo não pretende elucidar todas as questões sobre a Rosa Mosqueta, mas sim dar um passo a mais no conhecimento acerca de suas propriedades curativas. Como inovação, este trabalho apresenta à comunidade um produto inovador com potencial para o tratamento de feridas. Estudos clínicos de eficácia e segurança podem ser propostos em um futuro próximo a fim de se investigar a ação da Rosa Mosqueta em emulsão na cicatrização de feridas. 


\section{CONCLUSÃO}

As evidências científicas disponíveis na literatura para o uso do óleo de Rosa Mosqueta como agente cicatrizante são inconclusivas. Os estudos disponíveis possuem vieses metodológicos que não permitem uma indicação segura. Contudo, diversos estudos mostram um potencial clínico para a Rosa Mosqueta por sua concentração de ácidos graxos, compostos fenólicos e atividades antioxidantes e antiinflamatória in vitro e in vivo.

Os dados obtidos nesse trabalho permitem concluir que os estudos disponíveis sobre o uso do óleo de Rosa Mosqueta na cicatrização de feridas possuem nível de evidência fraca e baixa qualidade metodológica. Estudos clínicos bem conduzidos se fazem necessários para uma indicação ou refutação do uso clínico da Rosa Mosqueta no tratamento de feridas.

A elaboração de uma emulsão O/A a base de óleo de Rosa Mosqueta para tratamento de feridas mostrou-se viável e mesmo desejável ao garantir maior atividade antioxidante que o óleo puro por até 60 dias em condições de altas temperatura e umidade, que mimetizam o microambiente de uma ferida.

A emulsão O/A desenvolvida nesse estudo apresentou aspecto, $\mathrm{pH}$ e espalhabilidade compatível para uso tópico. A estabilidade fisico-química se manteve por 30 dias e a capacidade antioxidativa foi superior ao óleo puro, indicando que o uso de uma formulação no tratamento de lesões pode garantir proteção dos compostos biológicos contidos no óleo e aumentar sua eficácia. Além disso, o uso de fração menor de óleo torna a emulsão economicamente mais viável do que o óleo puro.

A solução oleosa de Rosa Mosqueta diluída até 30\% mostrou equivalência com o óleo puro pela comparação da capacidade antioxidativa e a concentração de betacarotenos, sugerindo que os compostos bioativos não sofrem interferência durante a diluição.

A carga microbiana das emulsões e das soluções oleosas analisadas apresentou decréscimo ao longo do tempo, podendo indicar uma possível ação bacteriostática do óleo.

A avaliação de eficácia da emulsão O/A desenvolvida com $30 \%$ de óleo de Rosa Mosqueta, bem como das soluções oleosas, in vivo, mostraram melhores resultados na prevenção de tecido necrótico e fibrinoso no leito da lesão quando comparado aos controles negativos e positivo. Além disso, o creme de Rosa Mosqueta 30\% aumentou o recrutamento de neutrófilos na fase inicial da cicatrização e modulou a resposta inflamatória na fase mais tardia. Esses dados mostram uma possível ação imunomodulatória no leito da lesão que pode ser de interesse clínico no tratamento de feridas, promovendo a liberação de fatores de crescimento e influxo celular para a ferida. 
Como perspectivas futuras, novos estudo de estabilidade podem ser conduzidos para a emulsão desenvolvida neste estudo em condições diversas de umidade e temperatura. Além disso, pode-se buscar aprimorar a formulação a fim de estender o prazo de validade da emulsão por meio da adição de agentes antioxidativos.

A possibilidade de uma ação bacteriostática do óleo de Rosa Mosqueta é interessante para o tratamento de feridas a fim de reduzir a ocorrência de biofilme. Entretanto, estudos microbiológicos específicos são necessários para comprovar essa teoria.

A fim de comprovar a eficácia da emulsão O/A com óleo de Rosa Mosqueta no tratamento de feridas, estudos clínicos serão fundamentais para fornecer uma indicação clínica adequada para o uso do produto. 


\section{REFERÊECIA}

ABREU, JAC. et al. Análise histológica da cicatrização de feridas cutâneas experimentaissob ação do laser de baixa potência. Scientia Medica, v. 21, n. 3, p. 96-100. Porto Alegre, 2011.

ANDERSON, U. et al. Rose hip exerts antidiabetic effects via mechanism involving down regulation of the hepatic lipogenic program.. American Journal of Physiology, Endocrinology and Metabolism, v. 300, , p. 111-121, 2011.

BALBINO, CA ; PEREIRA, LM ; CURI, R. Mecanismos envolvidos na cicatrização: uma revisão. Brazilian Journal of Pharmaceutical Sciences, v. 41, n. 1, 2005.

BELDON, P. Basic science of wound healing. Surgery, v. 28, n. 9, p. 409-12, 2010.

BRANCO NETO, MLC. et al. Avaliação do extrato hidroalcoólico de Aroeira (Schinus terebinthifolius Raddi) no processo de cicatrização de feridas em pele de ratos. Acta Cirúrgica Brasileira, v. 21, n. 2, p. 1-17, 2006.

BRASIL. Agência Nacional de Vigilância Sanitária. Farmacopéia Brasileira. versão 5 a Volume 1. Brasília, 2010.

Agência Nacional de Vigilância Sanitária. Guia de Estabilidade de Produtos

Cosméticos. Volume 1, Brasília, mai/2004..

Agência Nacional de Vigilância Sanitária. Guia de controle de qualidade de produtos cosméticos. versão $2^{\mathrm{a}}$. Brasília:Anvisa, 2008 .

Resolução - RDC n ${ }^{\circ}$ 14, de 31 de marÃßo de 2010. Diário Oficial [da] República Federativa do Brasil, Poder Executivo, Brasília, DF, 31 mar. 2010. Agência Nacional de Vigilância Sanitária. Disponível em: <http://www.brasilsus.com.br/legislacoes/rdc/10350714.html> Acesso em: Acesso em 15 de Junho de 2015. .

BROLMANN, FE. et al. Evidence-based decisions for local and systemic wound care. British Journal of Surgery, v. 99, p. 1172-1183, 2012.

CAMPOS, ACL ; BORGES-BRANCO, A ; GROTH, AK. Cicatrização de feridas. Arquivo Brasileiro de Cirurgia Digestiva, v. 20, n. 1, p. 51-8, 2007.

CAÑELLAS, M ; ESPADA, N ; OGALLA, JM. Estudio del aceite de rosa mosqueta en cicatrices postquirúrgicas. El Peu, v. 28, n. 1, p. 9-13, 2008.

CARVALHO, ACB. et al. Aspectos da legislação no controle dos medicamentos fitoterápicos. T\&C Amazônia, v. 11, ano V, jun/2007.

CASTELO-BRANCO VN, TORRES AG. Capacidade antioxidante total de óleos vegetais comestíveis: determinantes químicos e sua relação com a qualidade dos óleos. Revista de Nutrição, v. 24, n. 1, 2011. 
CHRUBASIK, C. et al. A systematic review on the Rosa canina effect and efficacy profiles. Phytotherapy Researc, v. 22, p. 725-33, 2008.

CHRUBASIK, C ; DUKE, RK ; CHRUBASIK, S. The evidence for clinical efficacy of Rose Hip and seed: a systematic review. Phytoterapy, v. 20, p. 1-3, 2006.

CUNJA, V. et al. Frost decreases content of sugars, ascorbic acid and some quercetin glycosides but stimulates selected carotenes in Rosa canina hips. Journal of Plant Physiology, v. 178, p. 55-63, 2015.

DAELS-RAKOTOARISON, DA. et al. Effects of Rosa canina fruit extract on neutrophil respiratory burst. Phytotherapy Research, v. 16, n. 2, p. 157-61, 2002.

DAMY, SB. et al. Aspectos fundamentais da experimentação animal - aplicações em cirurgia experimental. Revista da Associação Médica Brasileira, v. 56, n. 1, p. 103-11, 2010.

DEALEY, C. Cuidando de feridas: um guia para enfermeiras. $3^{\mathrm{a}}$. ed. São Paulo: Atheneu, 2008. Cap. 3.

DIEGELMANN, RF. Cellular and biochemical aspects of normal and abnormal wound healing: an overview. The Journal of Urology, v. 157, p. 298-3, Jan/1997.

DOGAN, A ; KAZANKAYA, A. Fruit properties of Rose Hip species grown in Lake Van Basin (eastern Anatolia Region). Asian Journal of Plants Science, Turquia. v. 5, n. 1, p. 120-2, 2006.

DOWSET, C; et al. Triangle of wound assessment made easy. Wounds International. May/2015.

DRISCOLL, DF. et al. Physicalchemical stability assessments of lipids emulsions of varing oil composition. Clinical Nutrition, v. 20, n. 2, p. 151-7, 2001.

EBAH. A pele e o processo de cicatrização. Disponível em

http://www.ebah.com.br/content/ABAAAAP7MAD/a-pele-processo-cicatrizacao. Acesso em 06 de novembro de 2016.

EGGERS, R ; AMBROGI, A ; SCHNITZLER, J Von. Special features of scf solid extraction of natural products: deoiling of wheat gluten and extraction of rose hip oil. Brazilian Journal of Chemical Engineerinf, Technical University of Hamburg - Hamburg, Germany. v. 17, n. 3 , p. 1-8, 2000.

EURIDES, D. et al. Efecto del extracto de rosa mosqueda (Rosa aff. rubiginosa) em la cicatrización de heridas cutáneas. Revista Eletrônica de Veterinaria, v. 12, n. 1, p. 1-10, 2011.

FALCÃO, SC. et al. Processo modificado de reprodução e amplificação de imagem para mensuração de área por planimetria. Aplicação em feridas planas produzidas em cães, tratadas por curativos oclusivos de pele de rã. Brazilian Journal of Veterinary Research and Animal Science, São Paulo. v. 38, n. 4, p. 165-9, 2001. 
FAGUNDES DJ, TAHA MO. Modelo animal de doença: critérios de escolha e espécies de animais de uso corrente. Acta Cirúrgica Brasileira, v. 19, n.1, 2004.

FAN, K. et al. State of the art in topical wound-healing products. Plastic and Reconstructive Surgery, v. 127 (Suppl.), p. 44S-59S, 2011.

FERREIRA, AM. et al. Utilização dos ácidos graxos no tratamento de feridas: uma revisão integrativa da literatura nacional. Revista da Escola de Enfermagem USP, v. 46, n. 3, p. 752-60, 2012.

FRANGE, RC ; GARCIA, MTJ. Desenvolvimento de emulsões óleo de oliva/água: avaliação da estabilidade física. Revista de Ciências Farmacêuticas Básica e Aplicada, v. 30, n. 3, p. 263-71, 2009. ISSN 1808-4532.

FROMM, M. et al. Identification and quantitation of carotenoids and tocopherols in seed sils recovered from different rosaceae species. Journal Agricultural and Food Chemistry, v. 60, n. 43, p. 10733-42, 2012.

FUJI, T ; IKEDA, K ; SAITO, M. Inibitory effect of Rose Hip (Rosa canina sp) on melanogenesis im mouse melanoma cells and on pigmentation in brown guinea pigs. Bioscience, Biotechnology and Biochemistry, v. 75, n. 3, p. 489-95, 2011.

FUNCK, LG ; BARRERA-ARELLANO, D ; BLOCK, JM. Ácido linoléico conjugado (cla) e sua relação com a doença cardiovascular e os fatores de risco associados. Archivos Latinoamericanos de Nutrición, v. 56, n. 2, 2006.

GIL, ES ; MATIAS, R ; ORLANDO, RM. Métodos de identificação. In: GIL, ES; MATIAS, R; ORLANDO, RM. Controle físico-químico de qualidade de medicamentos. Única. ed. São Paulo: Pharmabooks, 2010. Cap. 09.

GIL, ES; et al. Estabilidade de fármacos e medicamentos. In: GIL, ES; MONTALVÃO, EV; BATISTA FILHO, ROP. Controle físico-químico de qualidade de medicamentos. Única. ed. São Paulo: Pharmabooks, 2010. Cap. 17.

GIMENEZ, JCM. et al. Tratamiento de las úlceras cutáneas con aceite de rosa de mosqueta. Medicina Cutanáea IberoLatinoAmericana, v. 18, n. 1, p. 63-66, 1990.

GODOY, JMP ; PRADO, PA. Ácidos gordos essenciais enriquecidos com vitamina A, E e ácido linoleico como pensos em feridas crónicas. Revista Portuguesa de Clínica Geral, v. 21, p. 193-5, 2005.

HAKANSSON, A. et al. Rose hip and Lactobacillus plantarum DSM 9843 reduce ischemia/reperfusion injury in the mouse colon. Digestive Disease and Science, v. 51, p. 1094-2101, 2006.

IRION, GL. Feridas: novas abordagens, manejo clínico e atlas em cores. $2^{\mathrm{a}}$. ed. Rio de Janeiro: Guanabara Koogan, 2012. Cap. 2 e 12.

JADAD, AR. et al. Assessing the quality of reports of randomized clinical trials: is blinding necessary?. Controlled Clinical Trials, v. 17, n. 1, p. 1-12, Feb/1996. 
KANASHIRO, A. et al. Inhibitory activity of flavonoids from Lychnophora sp. on generation of reactive oxygen species by neutrophils upon stimulation by immune complexes. Phytotherapy Research, v. 18, n. 1, p. 61-5, 2004.

KAZANKAYA, A. et al. Pomological description of Rosa canina selections from Estern Anatolia Turkey. International Journal of Botany, v. 1, n. 1, p. 100-2, 2005.

KHARAZMI, A ; WINTHER, K. Rose hip inhibits chemotaxis and chemiluminescence of human peripheral blood neutrophils in vitro and reduces certain inflammatory parameters in vivo. Scandinavian Journal of Rheumatology, v. 34, p. 302-8, 2005.

KLEIN, T. et al. Fitoterápicos: um mercado promissor. Revista Ciências Farmacêuticas Básica e Aplicada, v. 30, n. 3, p. 241-8, 2009.

KNORST, M. T. Desenvolvimento tecnológico de forma farmacêutica plástica contendo extrato concentrado de Achyrocline satureioides (Lam.) Compositae - marcela, 1991. 228 f. Dissertação (Mestrado em Farmácia) - Curso de Pós-Graduação em Ciências Farmacêuticas, UFRGS, Porto Alegre, 1991.

LARSEN, E. et al. An anti-inflammatory galactolipid from rose hip (Rosa canina) that inhibits chemotaxis of human peripheral blood neutrophils in vitro. American Chemical Society and American Society of Pharmacognosy. Journal of Natural Products, v. 66, n. 7, p. 994-5, 2003.

LAZARUS, GS. et al. Definitions and guidelines for assessment of wounds and evaluation of healing. Wound Repair And Regeneration, v. 2, n. 3, p. 165-70, July-Sep/1994.

LATANZZIO, F et al. In vivo anti-inflammatory effect of Rosa canina L. extract. Journal of Ethnopharmacology ., v. 137, p. 880-5, 2011.

MACHMUDAH, S. et al. Process optimization and extraction rate analysis of carotenoids extraction from rosehip fruit using supercritical CO2. Journal Supercritical Fluids, v. 44, n. 3, p. 308-14, 2008.

MADJAROF, C ; LINARELLI, MCB. Estudo da eficácia percebida na melhora da textura, elasticidade e aparência geral de cicatrizes hipertróficas, através da aplicação do produto cosmético Renopel®. Revista Brasileira de Medicina, v. 68, n. 5, Mai/2011. S003472642011007600005 .

MARCHINI, FB. Estudo morfológico e morfométrico da cicatrização de feridas cutâneas abertas em ratos albinos com e sem tratamento com óleo de Rosa Mosqueta. Universidade de São Paulo - Unifesp, Escola Paulista de Medicina, Departamento de Cirurgia Plástica, São Paulo. 1994 . (Dissertação-Mestrado).

MARCHINI, Fb. et al. Efeito do óleo de Rosa Mosqueta na cicatrizaçäo de feridas abertas(letter). Revista Paulista de Medicina, v. 106, n. 6, p. 356, 1988.

MARQUES, RG. Técnica operatória e cirurgia experimental. Rio de Janeiro: Guanabara Koogan, 2005. Cap. 01. 
McDOUGALL, S. et al. Fibroblast migration and collagen deposition during dermal wound healing: mathematical modelling and clinical implications. Philosophical Transactions of the Royal Society A, v. 364, p. 1385-405, 2006.

MENDONÇA, RJ ; COUTINHO-NETO, J. Aspectos celulares da cicatrização. Anais Brasileiros de Dermatologia, v. 84, n. 3, p. 257-62, 2009.

MOLEZZI, A ; ALBEDAÑO, A. Fitomedicina: usos más comunes en

Dermatología. Dermatología Argentina, Buenos Aires, Argentina. v. VIII, n. 3, 2002.

MOLICA, EM. Caracterização in vitro de compostos bioativos em cucurbitáceas e sua aplicação no desenvolvimento de produto para nutrição cutânea. Programa de Pós-Graduação em Nutrição Humana, Departamento de Nutrição, Faculdade de Ciências da Saúde, Universidade de Brasília, Brasília, Distrito Federal, 2015. (Tese)

MORAIS, GG. Desenvolvimento e avaliação da estabilidade de emulsões O/A com cristais líquidos acrescidas de xantina para tratamento da hidrolipodistrofia ginóide (celulite). Faculdade de Ciências Farmacêuticas de Ribeirão Preto, Universidade de São Paulo - USP, Ribeirão Preto. 2006. (Dissert.).

NEVES, SMP. Manual de cuidados e procedimentos com animais de laboratório do Biotério de Produção e Experimentação da FCF-IQ/USP / Silvânia M. P. Neves [et al.]. -- São Paulo : FCF-IQ/USP, 2013. 216 p.

NovidermPortugal. A estrutura da pele: a epiderme. Disponível em:

<https://www.youtube.com/watch?v=jwJ-A4HcnKM.> Acesso em: 03 jul. 2016.

OLIVEIRA, BRGB ; CASTRO, JBA ; ANDRADE, NC. Técnicas utilizadas na aferição de feridas e avaliação do processo cicatricial. Saúde Coletiva, v. 2, n. 6, p. 57-62, 2005.

ORHAN, DD ; HARTEVIOGLU, A. The chemical composition and biological activity of Rose Hip. Spatula DD, v. 3, n. 1, p. 23-30, 2013.

OXFORD CENTRE FOR EVIDENCE-BASED MEDICINE.. OCEBM. The Oxford 2011 Levels of Evidence. Levels of Evidence Working Group*. Disponível em:

<http://www.cebm.net/index.aspx?o=5653> Acesso em: 15 fev. 2016.

PAREJA, B. Plantas medicinales con aplicaciones en dermatología y

cosmética. Dermofarmácia: Folia Dermatológica Peruana, v. 7, n. 3/4, dec/1996. Disp. em: sisbib.unmsm.edu.pe/.../images/pag49b_fig1.jpg..

PATEL, S. Rose hip as complementary and alternative medicine: overview of the present status and prospects. Mediterranean Journal of Nutrition and Metabolism, v. 6, n. 2, p. 89-97, Aug/2013.

PEREIRA, LM et al. Effect of oleic and linoleic acids on the inflamatory phase of wound healing in rats. Cell Biochemistry and Function, 2008; 26: 197-204. 
PLANTAMED. Rosa Canina L.. Disponível em:

<http://www.plantamed.com.br/plantaservas/especies/Rosa_canina.htm> Acesso em: 13 dez. 2015.

PLANTAS Ervas. Disponível em:

<http://www.plantaservas.hpg.ig.com.br/arquivos/ervas/rosa-mosqueta.htm.> Acesso em: 13 fev. 2015.

PRIOR, RL ; WU, X ; SCHAICH, K. Standardized methods for the determination of antioxidant capacity and phenolics in foods and dietary supplements. Journal of Agricultural Food Chemistry, v. 53, p. 4290-302, 2005. doi: 10.1021/jf05 02698.

RE, R. et al. Antioxidant activity applying an improved ABTS radical cation decolorization assay. Free Radical Biology and Medice, v. 26, n. 9/10, p. 1231-7, May/1999.

REIS, CLD. et al. Mensuração de área de úlceras por pressão por meio dos softwares Motic e AutoCAD®. Revista Brasileira de Enfermagem, Brasília. v. 65, n. 2, p. 304-8, mar$\mathrm{abr} / 2012$.

RODRIGUES, LM; et al. Oral administration of oleic or linoleic acid accelerates the inflammatory phase of wound healing. Journal of Investigative Dermatology, v. 132, p. 208-215, 2012.

RODRIGUES, LM. Desenvolvimento e estudo de estabilidade preliminar de emulsões óleo/água (o/a) a base de óleos vegetais para prevenção e/ou adjuvante no tratamento de úlceras por pressão. Universidade de Brasília, Faculdade de Ceilândia, Departamento de Farmácia, Brasília. 2013. (Monografia).

ROMAN, I ; STANILA, A ; STANILA, S. Bioactive compounds and antioxidant activity of Rosa canina L. biotypes from spontaneous flora of Transylvania. Chemistry Central Journal, v. 7, n. 73, 2013.

ROUBELAKIS, MG. et al. Platelet-rich plasma (PRP) promotes fetal mesenchymal stem/stromal cell migration and wound healing process. Stem Cell Review and Reports, v. 10, p. 417-28, 2014.

SÁ, H P. et al. Estudo comparativo da ação do laser GaAlInP e do gerador de alta frequência no tratamento de feridas cutâneas em ratos: estudo experimental. ConScientiae Saúde, v. 9, n. 3, p. 360-6, 2010.

SAABY, L. et al. Isolation of immunomodulatory triterpene acids from a standardized Rose Hip Powder (Rosa canina L.). Phytoterapy, v. 25, p. 195-201, 2011.

SAAR SRC, LIMA VLAN. Avaliação da pessoa portadora de ferida. In: BORGES EL, SAAR SRC, MAGALHÃES MBB, GOMES FSL, LIMA VLAN. Feridas: como tratar. $2^{\mathrm{a}}$ Edição. Belo Horizonte: Coopmed, 2010. Cap. 5.

SALMINEN, JP. et al. Characterization of proanthocyanidin aglycones and glycosides from Rose hips by high-performance liquid chromatography-mass spectrometry, and their rapid 
quantification together with vitamin C. Journal of Chromatography, v. 1077, p. 170-80, 2005.

SANTOS, JS ; VIEIRA, ABD ; KAMADA, I. A Rosa Mosqueta no tratamento de feridas abertas: uma revisão. Revista Brasileira de Enfermagem, v. 62, n. 3, p. 457-62, jun/2009. http://www.scielo.br/scielo.php?script=sci_arttext\&pid=S0034-

$71672009000300020 \& \operatorname{lng}=\mathrm{en}$. .

SAVIAN, AL. et al. Desenvolvimento e avaliação preliminar da estabilidade de emulsão nãoiônica O/A contendo óleo de café verde como potencializador de fator de proteção solar. Revista Brasileira de Farmácia, v. 91, n. 2, p. 82-8, 2011.

SCHANAIDER, A.; SILVA, PC. Uso de animais em cirurgia experimental. Acta Cirúrigca Brasileira. [serial online]; v. 19, n. 4, Jul-Ag/2004.

SMANIOTTO, PHS. et al. Tratamento clínico das feridas: curativos. Revista de Medicina, São Paulo, v. 89, n. 3/4, p. 137-41, jul-dez/2010.

SMANIOTTO, PHS. et al. Sistematização de curativos para o tratamento clínico de feridas. Revista Brasileira de Cirurgia Plástica, v. 27, n. 4, p. 623-6, 2012.

SOUZA, MT ; SILVA, MD ; CARVALHO, R. Revisão integrativa: o que é e como fazer. Einstein, v. 8, n. 1, p. 102-6, 2010.

SZENTMIHÁLYI, K. et al. Rose hip (Rosa canina L.) oil obtained from waste hip seeds by different extraction methods. Bioresource Technology, v. 82, n. 2, p. 195-201, 2002.

THIELEMANN, AM. et al. Determinación de la eficácia de una crema com aceite de Rosa Mosqueta en la atenuación de arrugas. Na. Real Acd. Farm., v. 59, n. 2, p. 211-18, 1993.

THOMPSON, JE. A prática farmacêutica na manipulação de medicamentos. Porto Alegre: Artmed, 2006. Cap. 22, 30 e 34.

TUMBAS, VT. et al. Characterization of the free radical scavenging activity of Rose Hip (Rosa canina L.) extract. International Journal of Food Properties, v. 15, p. 188-201, 2012.

TUMBAS, VT. et al. Effect of rosehip (Rosa canina L) phytochemicals on stable free radicals and human cancer cells. Journal of the Science of Food and Agriculture, 92:1273-1281, 2012.

TURK, HF et al. Inhibitory effects of ômega-3 fatty acids on injury -induced epidermal growth factor receptor transactivation contribute to delayed wound healing. Am J Physiology Cell Physiology 304: 905-17, 2013.

URSI, ES ; GALVÃO, CM. Prevenção de lesões de pele no perioperatório: revisão integrativa da literatura. Revista Latino-americana de Enfermagem, v. 14, n. 1, p. 124-31, Janfev/2006.

VADAS, EB. Estabilidade de produtos farmacêuticos. In: GENNARO, AR. A ciência e a prática da farmácia. 20ª . ed. Rio de Janeiro: Guanabara Koogan, 2004. Cap. 52. 
VALDEBENITO, G. et al. Innovación tecnológica y comercial de productos forestales no madereros (PFNM) en Chile. Proyecto Fondef - Infor - Fundacion Chile. Proyecto FONDEF D00I104, Chile. jul/2003..

VALLADARES, J. et al. Crema de aceite de mosqueta (rosa aff. Rubiginosa 1.). I. Parte: formulación, preparación y aplicación primaria en regeneración de tejidos. Anales da Real Academia de Farmacia, v. 52, n. 3, p. 597-612., 1986.

VELASCO,. et al. Desenvolvimento e Teste Preliminar da Estabilidade de formulações cosméticas acrescidas de extrato comercial de Trichilia catigua Adr. Juss (e) Ptychopetalum olacoides Bentham. Revista de Ciências Farmacêuticas Básica e Aplicada, v. 29, n. 2, p. 181-96, 2008.

WARHOLM, O. et al. The effects of a standardized herbal remedy made from a subtype of Rosa canina in patients with osteoarthritis: a double-blind, randomized, placebo-controlled clinical trial. Current Therapeutic Research Clinical and Experimental, v. 64, n. 1, p. 2131, 2003.

WENZIG, EM. et al. Phytochemical composition an in vitro pharmacological activity of two rose hip (Rosa canina L.) preparations. Phytomedicine, v. 15, p. 826-35, 2008.

WILLIAMSON, D ; HARDING, K. Wound healing. Medicine, v. 32, n. 12, p. 4-7, 2004.

WILLICH, SN. et al. Rose hip herbal remedy in patients with rheumatoid arthritis - a randomised controlled trial. Phytomedicine, v. 17, p. 87-93, 2010.

WINTHER, K ; CAMPBELL-TOFTE, J ; HANSEN, P. Rose hip powder that contains the natural amount of shells and seeds alleviates pain in osteoarthritis of the dominant hand - a randomized, double-blind, placebo-controlled, cross-over clinical trial. Open Journal of Rheumatology and Autoimmune Diseases, v. 3, p. 172-80, 2013.

YOON, HS ; KIM, YK ; CHUNG, JH. High-concentration all-trans retinoic acid induces dermal inflammation and reduces the accumulation of type I procollagen in human skin in vivo. British Association of Dermatologists, v. 165, p. 669-72, 2011.

YOUNG, A ; MCNAUGHT, C. The physiology of wound healing. Surgery, v. 29, n. 10, p. 475-9, 2011. 